\title{
Hydrodynamics of Liquid-Liquid Flows in Micro Channels and Its Influence on Transport Properties: A Review
}

\author{
Arijit A. Ganguli ${ }^{1,2, *}$ and Aniruddha B. Pandit ${ }^{2}$ \\ 1 School of Engineering and Applied Sciences, Ahmedabad University, Ahmedabad 380009, India \\ 2 Chemical Engineering Department, Institute of Chemical Technology, Matunga, Mumbai 400019, India; \\ dr.pandit@gmail.com or ab.pandit@ictmumbai.edu.in \\ * Correspondence: ganguliarijit@gmail.com or arijit.ganguli@ahduni.edu.in; Tel.: +91-8861817755
}

Citation: Ganguli, A.A.; Pandit, A.B. Hydrodynamics of Liquid-Liquid Flows in Micro Channels and Its Influence on Transport Properties: A Review. Energies 2021, 14, 6066. https://doi.org/10.3390/en14196066

Academic Editor: Noam Lior

Received: 17 July 2021

Accepted: 15 September 2021

Published: 23 September 2021

Publisher's Note: MDPI stays neutral with regard to jurisdictional claims in published maps and institutional affiliations.

Copyright: (c) 2021 by the authors. Licensee MDPI, Basel, Switzerland. This article is an open access article distributed under the terms and conditions of the Creative Commons Attribution (CC BY) license (https:// creativecommons.org/licenses/by/ $4.0 /)$.

\begin{abstract}
Hydrodynamics plays a major role in transport of heat and mass transfer in microchannels This includes flow patterns and flow regimes in which the micro-channels are operated. The flow patterns have a major impact the transport properties. Another important aspect is the pressure drop in micro-channels. In the present review, the experimental and Computational Fluid Dynamics (CFD) studies covering all the above aspects have been covered. The effect of geometrical parameters like shape of channel, channel size, material of construction of channels; operating parameters like flow velocity, flow ratio and fluid properties have been presented and analyzed. Experimental and analytical work of different pressure drop models has also been presented. All the literature related to influence of flow patterns on transport properties like volumetric mass transfer coefficients (VMTC) and heat transfer coefficients (HTC) have been presented and analyzed. It is found that most works in Liquid-Liquid Extraction (LLE) systems have been carried out in slug flow and T-junctions. Models for coupled systems of flow and mass transfer have been presented and works carried out for different coupled systems have been listed. CFD simulations match experimental results within $20 \%$ deviations in quantitative and qualitative predictions of flow phenomena for most research articles referred in this review. There is a disparity in prediction of a generalized regime map and a generalized regime map for prediction of flow patterns for various systems would need the help of Artificial Intelligence.
\end{abstract}

Keywords: microchannels; flow patterns; CFD; pressure drop; high speed camera; particle tracking velocimetry

\section{Introduction}

Microchannels have been an area of interest since the last two decades in various applications including petroleum industries, emulsification, fine and speciality chemicals (like nitration reactions), extraction processes, biochemical applications etc. Flow patterns play a vital role in the transport properties (heat and mass transfer) in non-reactive and reactive systems. Conventional equipments like agitated vessels, rotating discs, impinging jets (for mass transfer) [1] and jet impinge heat exchange mechanisms used for cooling gas turbine components, heat treatments, [2] preheating in glass manufacturing [3] and many other conventional heat transfer equipments [4] have order of magnitude lower transport properties than those offered by microchannels. Flow patterns are formed due to interplay between inertial and surface tension forces. The gravitational forces are of less importance in the microchannel based devices and systems. The viscosities differences of the continuous and dispersed phases give rise to several different flow patterns. The dimensionless numbers used in investigations are: Reynolds number: $R e=\frac{\rho v D}{\mu}$; Capillary number: $C a=\frac{\mu v}{\sigma}$; Weber number: $W e=R e^{*} C a$; Ohnesorge number: $O h=\frac{\mu}{\sqrt{D \sigma \rho}}$. Bond number: $B o=\Delta \rho g d^{2} / \sigma$. The same dimensionless numbers have been used for the inlet junction flow patterns. Excellent reviews have been published on different flow patterns 
as well as its effect on transport properties both in gas-liquid (GL) and liquid-liquid (LL) systems. [5,6]. However, reviews on flow patterns of LL systems focus on major flow patterns like slug-flow, parallel flow and transition flow. It is important to note that the viscosity of the continuous and dispersed phase gives rise to various different flow patterns $[7,8]$. Also, the flow patterns depend on the bubble formation and breakup during the tubing, squeezing and dripping regimes and transitions between them. Further, reviews [5] have focused mostly on the effect of geometrical and operating parameters, material of construction of microchannels but the effect of surfactants, effect of hydrophobicity and hydrophilicity on walls, effects of wall films on flow patterns have not been thoroughly discussed. The present work focuses on reviewing all the prominent literature works (including experimental, numerical works) on flow patterns and regime maps. First, state of the art of experimental and CFD studies describing flow patterns in liquid-liquid flows have been analyzed. This includes flow patterns in different geometries and geometrical parameters like shape, size, material of construction, operating parameters like flow rates, flow ratios, fluids properties of the fluids under consideration, measurement techniques used by researchers to understand internal circulations in slugs of both phases are also presented. Secondly, most important flow regime maps signifying the maps based on forces and based on dimensionless groups (individual and combination of different dimensional numbers have been presented. Finally, pressure drop in microchannels (experimental data) of various authors has been presented for different two phase systems and geometries. The corresponding models and their limitations have been presented. Finally, the review lists out the various liquid-liquid reactive and non-reactive systems carried out by researchers. Pressure drop studies has been covered well in recent review by Al-Azzawi et al. [5]. In the present work, the most prominent works have been reported. The prominent works showing effect of the flow patterns on transport properties (specifically Volumetric Mass Transfer Ceofficients (VMTC)) have been included. Figures 1 and 2 show the entire structure of the manuscript. Figure 1 focuses on the experimental studies while Figure 2 focuses on the CFD studies. 


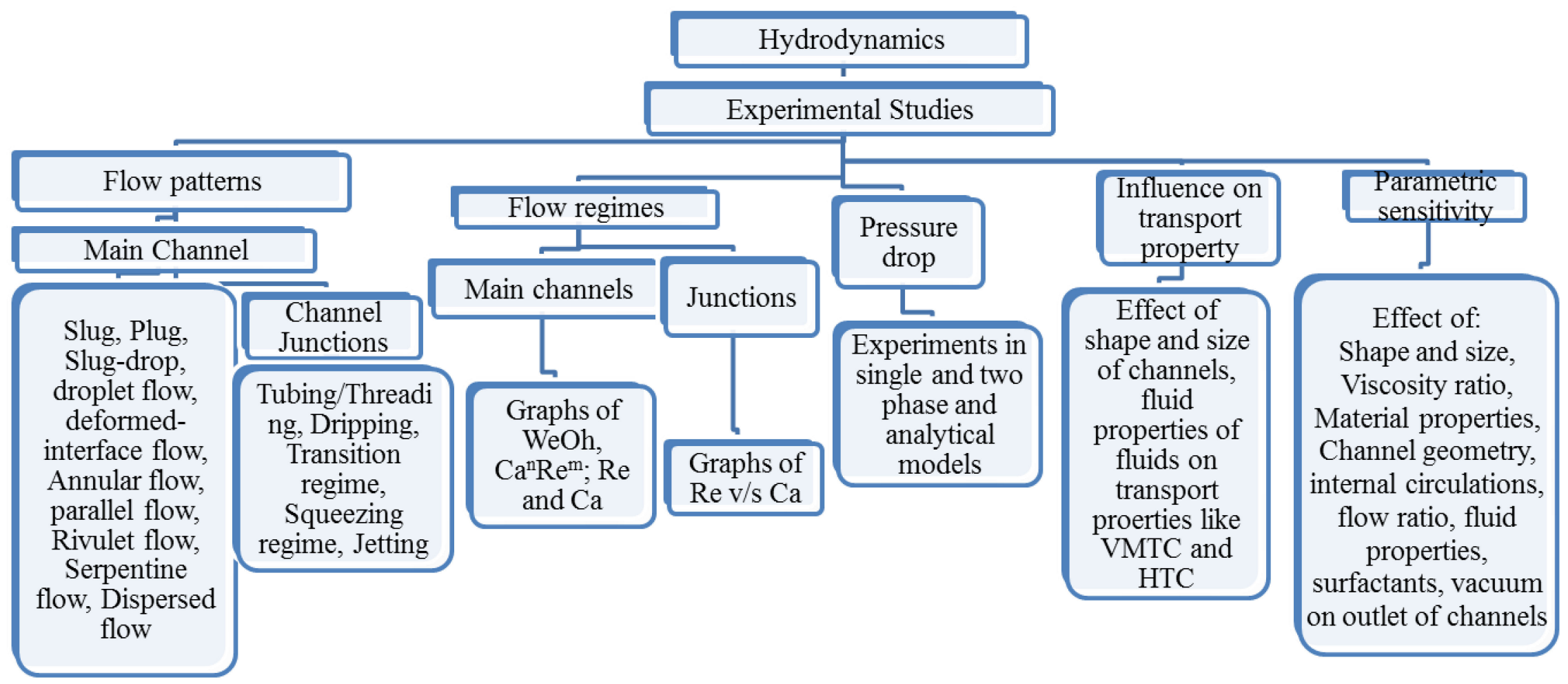

Figure 1. Flow structure of the experimental studies in the manuscript. Black arrows show interactions between flow patterns and other parameters andflow regimes. 


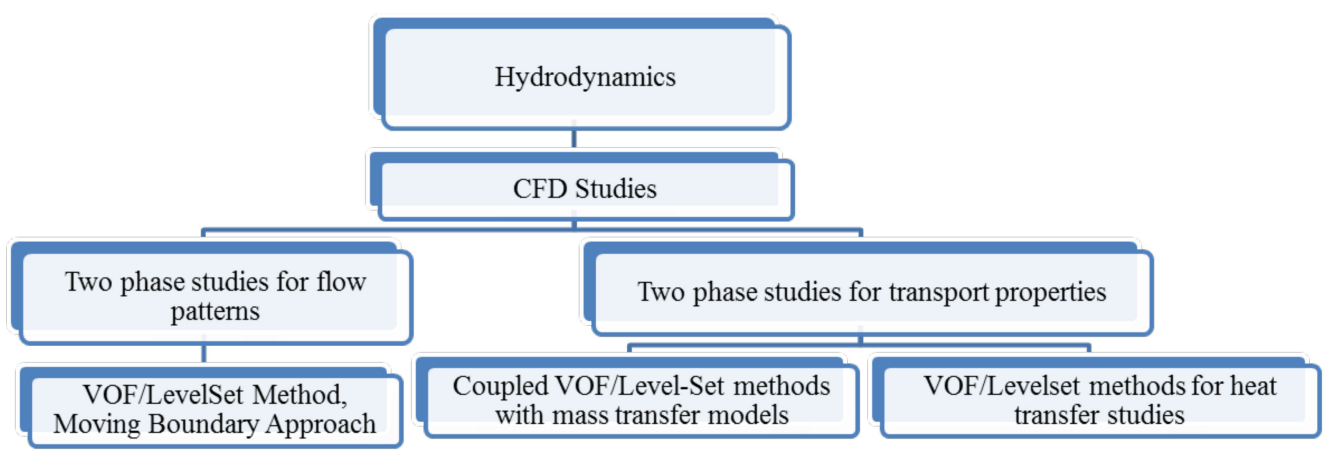

Figure 2. Flow structure of the CFD studies in the manuscript.

\section{Hydrodynamics in Microchannels}

Micro-channels provide advantages like high surface to volume ratio that ensures better control on size of the droplets. A typical experimental set-up for carrying out experiments to study flow patterns, mass transfer, pressure drop etc. is shown in Figure 3. The two immiscible liquids (aqueous and organic, from reservoirs (1 and 2) are introduced by continuously operating high-precision piston pumps ( 3 and 4 ) to a symmetric $120^{\circ}$ Y-junction or T-junction made of materials like Teflon, glass, steel etc. (5). The pumps are controlled with the help of a computer to adjust the flow rate. The capillary contactor (6) is made of poly-tetra-fluoro-ethylene (PTFE) and was attached directly downstream of the Y-or T junction. The length of the capillary micro-channel can be adjusted easily. Thus, the setup was very flexible with respect to the residence time used. At the end of the contacting stage, a flow splitter (7), was used to separate the phases.

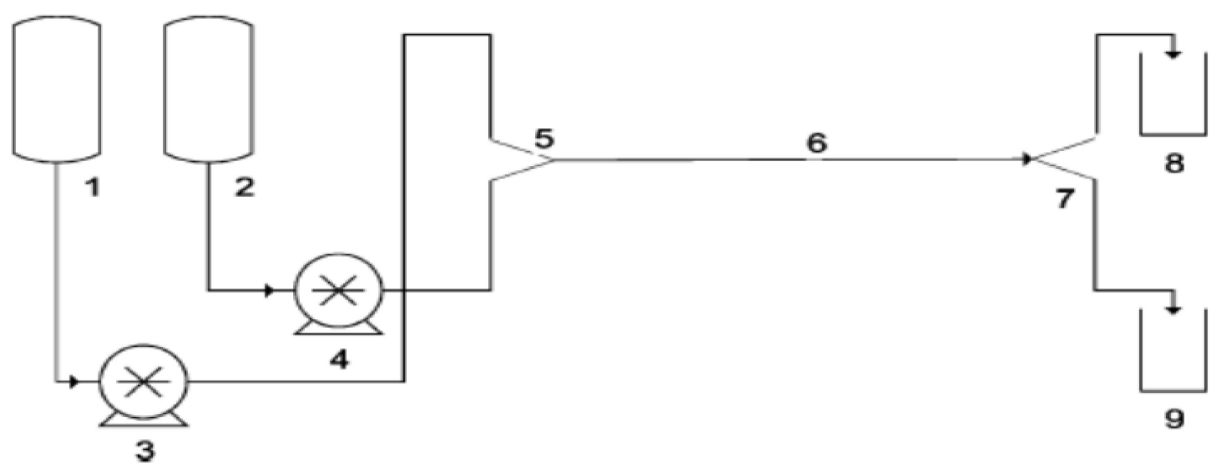

Figure 3. Schematic of the experimental setup $(\mathbf{1 , 2})$ Reservoirs containing aqueous and organic liquids respectively; (3,4) feed pumps; (5) Y-junction mixing element; (6) slug-flow capillary (7) flow splitter and $(8,9)$ sampling bottles. (Reproduced with permission from [9]) the two outlets of the splitter were collected in the sampling bottles $(\mathbf{8}, \mathbf{9})$ for further analysis. With permission from Kashid et al. [1].

Typical configurations for micro-channels are shown for in Figure 4. The micro-channel geometries are different in cross sectional shape, main channel shape and mixing junction configuration. Regarding the cross sectional shape of the micro-channel, micro-channels can be classified into two main groups: circular and non-circular micro-channels, the latter can be square, rectangular, trapezoidal, etc. Different types of junction configurations are used at the micro-channel entrance. The most popular mixing junctions are T-junction, Y-junction, cross-shaped junction, cross flow T-junction and concentric junction. The cross sectional dimension of the inlet channels can be different from those of the main channel. Different junction configurations can produce different stable flow regimes. For example, a micro-channel with a Y-shaped junction is more appropriate for producing a stable liquid- 
liquid parallel flow as compared to that with a T-shaped junction [9]. Droplet flow in a micro-channel can be achieved by using a concentric inlet or cross-shaped junction. Further, details into dispersion in micro-channels with different junction structures can be found in the literature [10-12].
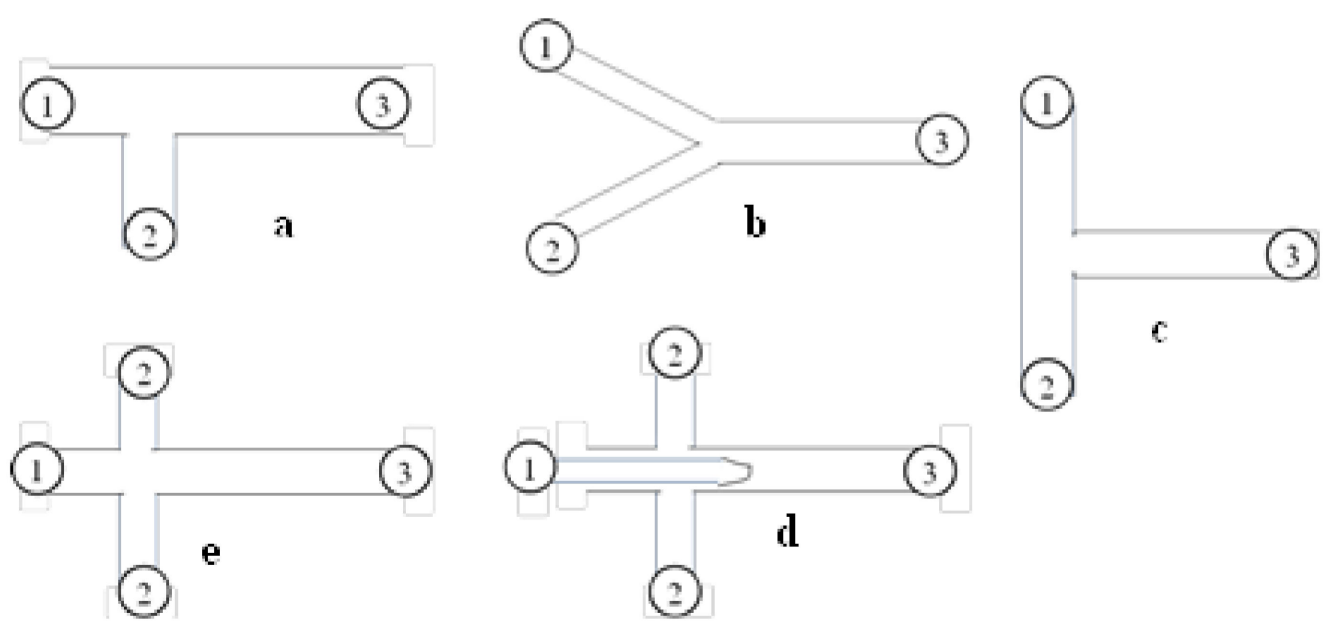

Figure 4. Types of micro-channels with different junctions 1 Inlet for continuous phase 2 Inlet for dispersed phase 3 Outlet of the channel (a) Cross flow T-junction (b) Y-junction (c) Cross Junction (d) Concentric junction (e) T-junction.

In the forthcoming sections, we will discuss about the flow patterns, pressure drop in micro-channels using $\mathrm{T}$ and $\mathrm{Y}$ junctions and review the current experimental and $\mathrm{CFD}$ modeling works.

\subsection{Experimental Studies: Flow Patterns, Flow Regimes, Pressure Drop}

In this section we present the various experimental works by the researchers for studying the different flow patterns occurring in micro-channels and how they have been represented using regime maps. Measured pressure drop for different two phase systems at different operating conditions and effect of material characteristics and operating parameters are also presented. Research works involving CFD simulations depend on mathematical modelling to track the interface and reproducing the experimentally observed flow patterns for different geometric and operating conditions have been presented.

Experimental research works mainly in published literature have mainly focused on flow patterns, internal circulations inside slugs [13] (in slug flows), flow regimes and pressure drop. Some analytical models for pressure drops have also been presented. These models have been validated with experimental works in literature.

\subsubsection{Flow Patterns}

Flow patterns are divided into two parts: the first and most significant is flow patterns in the main channel and second is the flow patterns in the junction. Flow patterns in microchannels have been studied explicitly by many researchers $[1,7,14-16]$. In micro-channels distinctly visible flow patterns are annular flow, parallel flow, slug flow, droplet flow and deformed interface flow provided by the authors $[6,7,15,16]$. Other flows which may form are slug-drop, slug-dispersed etc. depending on the operating parameters like flow rates of the two fluids. The viscosity of the fluids play a major role in determining some flow like rivulet and serpentine flow (Yagodnitsyna et al. [7]) instead of annular flows. Flow patterns at the junctions are carried out by a few researchers [11,17-21].

It should be noted that the flow patterns in main channels depend on which regime exists in the junctions. Different patterns are observed at cross-junctions and cross Tjunctions. The patterns of cross-junctions and cross-T junctions are Tubing/threading, dripping and jetting. Three different systems with different viscosities and surface tensions 
namely, water-kerosene, water-paraffin-oil and paraffin-oil-castor-oil were considered by researchers [7]. They observed rivulet flow and serpentine flow in addition to the flow observed mentioned previously.

The different types of flows in the main channel which are essentially due to the interplay between the shear, inertial and surface tension forces are as follows (Refer Figure 5):

1. Droplet flow: In this type of flow the dispersed phase flows in the form of droplets. The droplets have diameter quite lesser than the hydraulic diameter and have continuous renewal of surface due to the continuous phase flow (Figure 5a).

2. Slug flow: This is the most observed flow in micro-channels. When two miscible fluids are introduced into the junction, one fluid passes downstream while other penetrated over opposite side of the junction. This mutual displacement causes the slug flow structure (Kashid et al. [14]). In this type of flow, the dispersed phase flows in the continuous phase in the form of slugs. These slugs have a diameter and a slug length little lesser/same than the hydraulic diameter of the channel and if lesser due to the film thickness. The slugs are separated from each other with a specific distance from each other. There are internal circulations within the slugs which aid in decreasing the boundary layers near the interface of the dispersed and continuous phases thus promoting mass transfer. In addition to this, there are circulations in between the two slugs which promote diffusion (Figure $5 b$ ).

3. Slug-drop flow-The flow pattern is the intermediate pattern between the slug and deformed interface flow where drops are formed between slugs (Figure 5c).

4. Deformed interface flow: This type of flow occurs when the dispersed phase transitions from annular/parallel flow to form irregular droplets. Such flows occur when the flow rate of the dispersed phase is higher as compared to continuous phase (Figure 5d).

5. Annular flow: In this type of flow, one fluid (continuous phase) flows through the middle while the other fluid (dispersed phase) forms a thin film near the walls and flows near the walls. The shear force of the continuous phase is dominant over the surface tension in this case (Figure 5e).

6. Parallel flow: In this type of flow, both fluids flow in parallel to each other with an interface in the middle. Both the fluids touch the wall and wet it. Here, both wall shear and interfacial shear are dominant over the surface tension force (Figure $5 f$ ).

7. Plug flow: This type of flow is described differently by different authors. Plugs as liquid segments in symmetrical plug which does not necessarily wet the channel wall have been defined by Yagodnitsyna et al. [7]. The plug length is greater than the slug length.

8. Rivulet flow: This new flow pattern was observed by Yagodnitsyna et al. [7]. The authors defined the rivulet flow pattern to be a parallel flow when one of the liquids forms a rivulet which wets channel wall and its shape along the channel length can be warped (Figure $5 \mathrm{~g}$ ).

9. Serpentine flow: This new flow pattern was observed by Yagodnitsyna et al. [7]. In this type of flow, a periodical wavy interface (like a twisted tape) is observed. The periodical wavy interface is similar to the overlapping longitudinal and traverse mode vibrations in Melde's experiment and is stationary from beginning to end (Figure 5h).

10. Dispersed Flow: This type of flow might occur only if there is sufficient amount of mixing due to obstructions etc. We will see this flow in greater detail in the forthcoming sections. 
$\mathbf{a}$
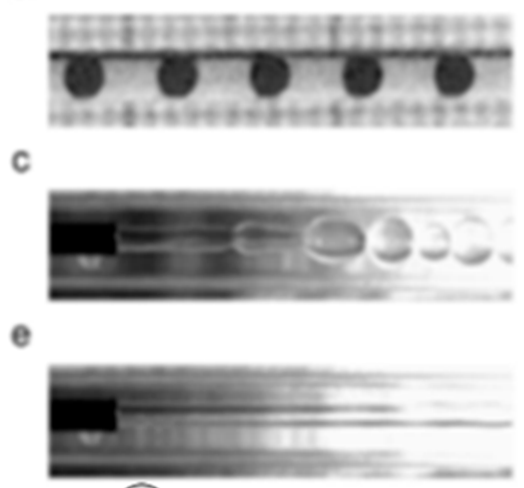

b

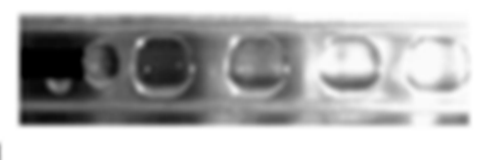

d

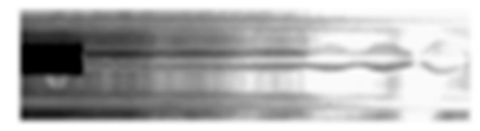

$f$
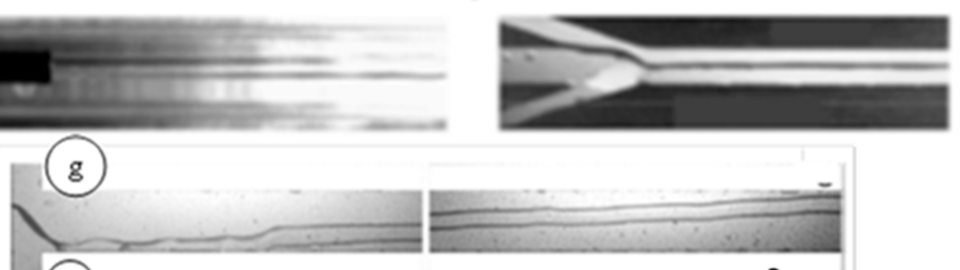

(h)

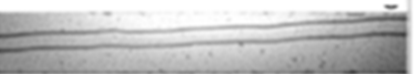

2
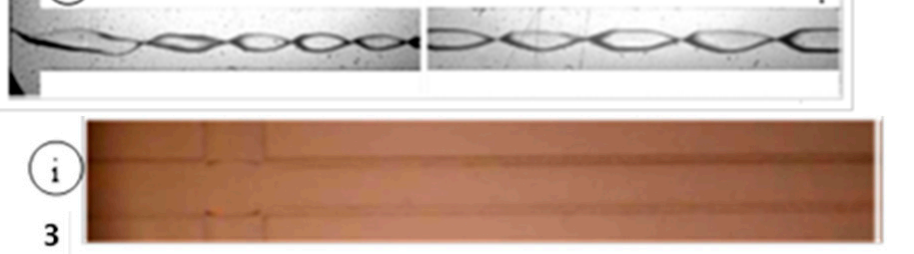

j

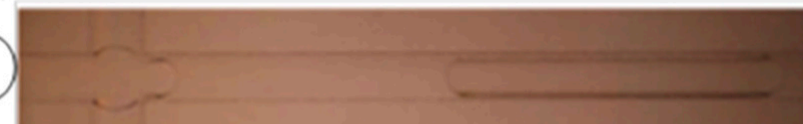

(k)

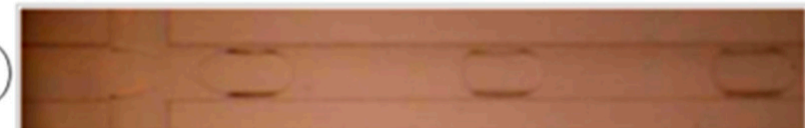

(1)

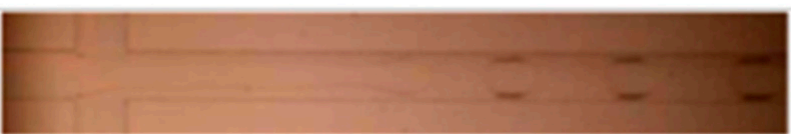

Figure 5. Flow regimes observed for liquid-liquid systems A. Main channels (1) Kashid et al. [6]: (a) Drop flow in a Y-junction capillary micro-channel (b) Slug flow in a concentric micro-channel (c) Slug-drop flow in a concentric micro-channel (d) Deformed interface flow in a concentric microchannel (e) Annular flow in a concentric micro-channel (f) Parallel flow in a wedge-shaped microchannel (2) Yagodnitsyna et al. [7] (g) rivulet flow (h) serpentine flow B. Channel Junctions (3) Wu et al. [11] (i) tubing (j) Squeezing (k) dripping (1) jetting. Reproduced with permission from authors.

The types of flows in the junctions are given below Wu et al. [11]: (explain in detail regarding the flow regimes)

1. Tubing/threading: In this type of flow, organic liquid flows from the junction in the form of an annular core in the main channel with minor interface deformations. Threading has a cylindrical organic core while tubing has approximate square cross section with round corners (Figure 5i)

2. Dripping: In this type of flow the organic core tends to largely obstruct the intersection which constricts the aqueous (water in the case considered by the authors) flow. Pressure is exerted by water coming in from both sides (i) squeezing pressure and (ii) viscous shear. Both these forces overcome the interfacial shear to send the organic droplet into main channel in the form of slug. (Figure 5j,k) Cubaud and Mason [17]. Inertial forces have no significant effect on the droplet formation due to proximity of $\operatorname{Re}<1$ for both phases. 
Droplet size variation depends on Ca number. For example, for $\mathrm{Ca}=0.019$ droplet size varies upto $15 \%$. While the variation is lower for $\mathrm{Ca}=0.011$ is higher than $15 \%$ [22].

3. Transition regime: This regime is transition from dripping to sqeezing regime. In transition regime the Ca numbers are in range $(0.009<\mathrm{Ca}<0.013)$ and $\mathrm{Re}<1$. Hence inertial forces have no significant effect on flow patterns

4. Sqeezing regime: In this regime the inertial forces play a big role.

5. Jetting: In this type of flow the organic core thread falls in certain distance into the outlet main micro-channel before it breaks up into slugs/droplets. At jet breakup, interfacial shear is overcome by viscous shear. (Figure 5l).

In the upcoming subsections, the effect of different parameters like geometrical parameters like shape, size of microchannels, material of construction of channels, type of junction for flow mixing and inlet, fluid properties of the dispersed and continuous phases like the viscosity ratio, interfacial tension and the effect of other factors like addition of agents or application of vacuum to stabilize flow patterns have been presented. Table 1 gives the literature works on the flow patterns while Figures 6 and 7 gives the chart showing the flow patterns due to the sensitivity of several parameters involved. 
Table 1. Details of literature works on flow patterns.

\begin{tabular}{|c|c|c|c|c|c|c|c|c|c|}
\hline \multirow[t]{2}{*}{ Authors } & \multicolumn{5}{|c|}{ Channel (CH) Details } & \multirow{2}{*}{$\begin{array}{c}\text { Type of Study } \\
\text { Experimental/CFD }\end{array}$} & \multirow[t]{2}{*}{ System } & \multirow[t]{2}{*}{ Flow Regime } & \multirow[t]{2}{*}{$\begin{array}{l}\text { Equipment } \\
\text { Used }\end{array}$} \\
\hline & Geometry Type & $\begin{array}{c}\mathrm{CH} \\
\text { Diameter/Size } \\
(\mathrm{mm})\end{array}$ & $\begin{array}{l}\text { CH Length } \\
(\mathrm{mm})\end{array}$ & CH Material & $\begin{array}{c}\text { Flow } \\
\text { Rate/Velocity } \\
(\mathrm{m} / \mathrm{s})\end{array}$ & & & & \\
\hline Su et al. [23] & $\begin{array}{c}\text { Square } \\
\text { microchannel }\end{array}$ & $0.6 \times 0.6$ & 2 & NA & $0.6 \mathrm{~mL} / \mathrm{min}$ & Experimental & $\begin{array}{c}\text { Glycerol- } \\
\text { kerosene; Oil } \\
\text { soluble } \\
\text { surfactant Span } \\
80\end{array}$ & Slug flow & $\begin{array}{l}\text { High Speed } \\
\text { CMOS Camera } \\
\text { system (Basler } \\
\text { A504KC) }\end{array}$ \\
\hline $\begin{array}{c}\text { Kashid and } \\
\text { Kiwi-Minsker } \\
\text { [24] }\end{array}$ & $\begin{array}{l}\text { T-square; } \\
\text { Y-rectangular; } \\
\text { Trapezoidal; } \\
\text { Concentric }\end{array}$ & $\begin{aligned} 0.4 & \times 0.4 \\
0.5 & \times 0.4 \\
0.25 & \times 0.292 \\
d & =0.5\end{aligned}$ & $\begin{array}{c}56 \\
75 \\
40 \\
200\end{array}$ & NA & $\begin{array}{c}5.8 \times 10^{-3} \\
\mathrm{~m}^{3} / \mathrm{s} ; 0.025 \mathrm{~m} / \mathrm{s}\end{array}$ & Experimental & Water- Toluene & $\begin{array}{c}\text { Slug flow; } \\
\text { Transition flow; } \\
\text { Annu- } \\
\text { lar/Parallel } \\
\text { flow }\end{array}$ & $\begin{array}{l}\text { High Speed } \\
\text { Camera }\end{array}$ \\
\hline $\begin{array}{c}\text { Kovalev et al. } \\
{[8]}\end{array}$ & T-junction & $\begin{array}{l}0.12 \times 0.12 \\
0.24 \times 0.12\end{array}$ & $11.5 ; 22.5$ & SU-8 & $\begin{array}{c}\left(2<Q_{c}<6\right. \\
\left.1.5<Q_{c}<20\right) \\
\mu \mathrm{L} / \min \end{array}$ & Experimental & $\begin{array}{c}\text { Castor } \\
\text { oil-Distilled } \\
\text { water }\end{array}$ & $\begin{array}{l}\text { Plug flow; Plug } \\
\text { flow with } \\
\text { suspended } \\
\text { particles; } \\
\text { Droplet Flow; } \\
\text { Throat annular; } \\
\text { Slug flow; } \\
\text { Parallel Flow }\end{array}$ & $\begin{array}{c}\text { High Speed } \\
\text { Camera; Particle } \\
\text { Tracking } \\
\text { Velocimetry }\end{array}$ \\
\hline $\begin{array}{c}\text { Svensson et al. } \\
\text { [25] }\end{array}$ & $\begin{array}{c}\text { Square } \\
\text { microchannel }\end{array}$ & $\begin{array}{l}0.6 \times 0.6 \\
0.4 \times 0.4 \\
0.6 \times 0.3\end{array}$ & 5 & Glass & $\begin{array}{l}\mathrm{Qc}=8 \mathrm{~mL} / \mathrm{h} ; \\
\mathrm{Qd}=2 \mathrm{~mL} / \mathrm{h}\end{array}$ & Experimental & Water-n-hexane & Slug flow & $\begin{array}{l}\text { High Speed } \\
\text { Camera }\end{array}$ \\
\hline $\begin{array}{c}\text { Vansteene et al. } \\
\text { [26] }\end{array}$ & $\begin{array}{l}\mathrm{T}, \mathrm{X} \text { Junction } \\
\text { microchannel }\end{array}$ & $0.1 \times 0.1$ & 1.125 & Glass & $\begin{array}{c}5.8 \times 10^{-3}< \\
\mathrm{Qd}<0.033 \\
\mathrm{~mL} / \mathrm{h} ; 0.07<\mathrm{Qc} \\
<11\end{array}$ & Experimental & $\begin{array}{l}\text { Water, dodecane, } \\
\text { nitric acid, } \\
\text { Hydrochloric } \\
\text { acid, } \\
\text { DMDBTDMA }\end{array}$ & $\begin{array}{l}\text { Segmented/Slug } \\
\text { flow }\end{array}$ & $\begin{array}{l}\text { High Speed } \\
\text { Camera mini } \\
\text { AX } 100\end{array}$ \\
\hline Li et al. [27] & Y channel & $0.24 \times 0.008$ & $2 \mathrm{~mm}$ & $\begin{array}{l}\text { PDMS, Glass; } \\
\text { Quartz }\end{array}$ & $\begin{array}{c}40<\mathrm{u}_{\mathrm{d}}<400 \\
\mu \mathrm{m} / \mathrm{s} ; 100<\mathrm{u}_{\mathrm{c}}< \\
1000 \mu \mathrm{m} / \mathrm{s}\end{array}$ & Experimental & Oleic acid-water & Parallel flow & $\begin{array}{l}\text { TS-100S nikon } \\
\text { Japan }\end{array}$ \\
\hline
\end{tabular}


Table 1. Cont.

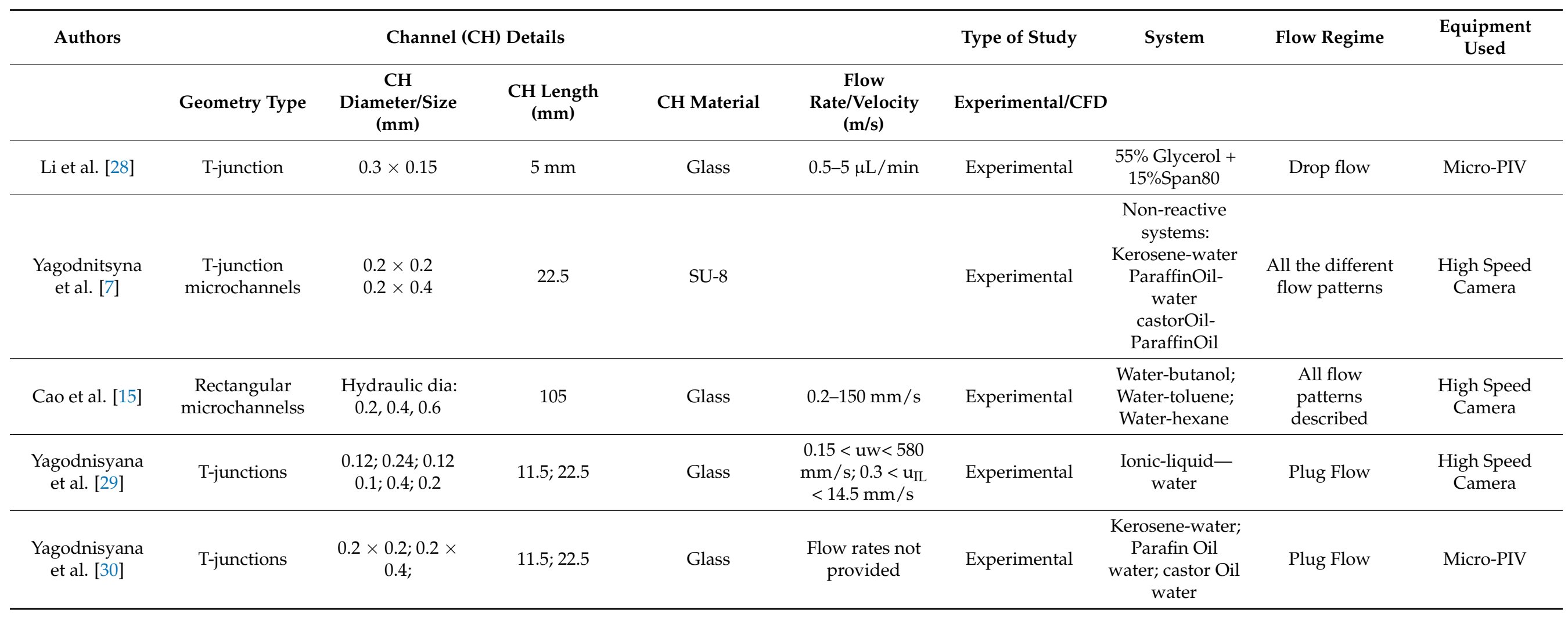




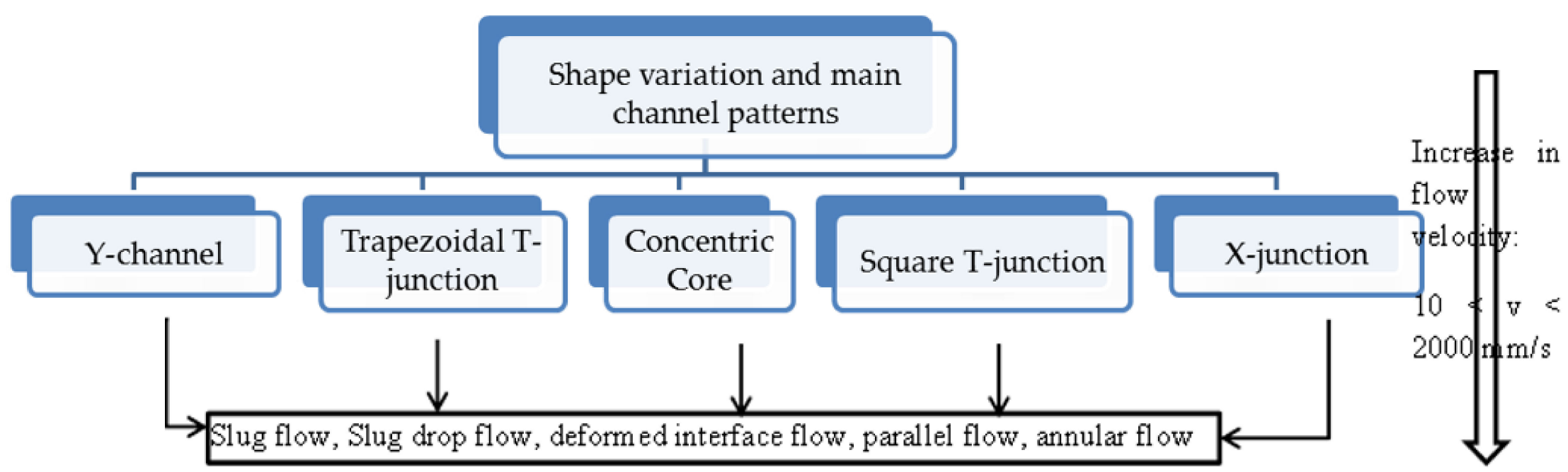

Figure 6. Different flow patterns for different shapes of microchannels studied by authors. 


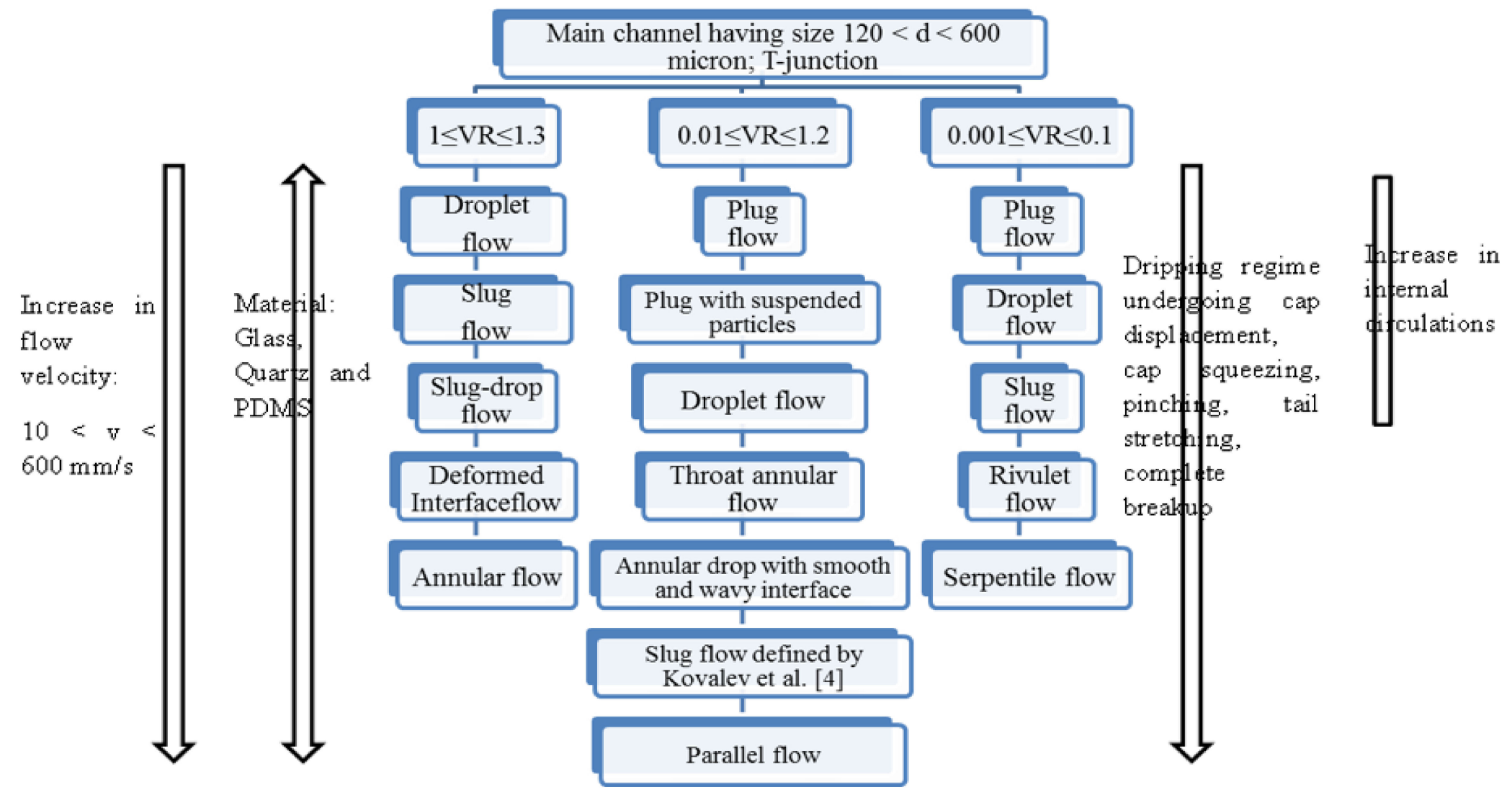

Figure 7. Chart showing interactions between flow patterns and different geometric and operating parameters structures and shapes. VR represents viscosity ratio. 


\section{Role of Shape, Size, Geometry and Material Properties of Microchannels}

Svenssen et al. [25] investigated the effect of square and rectangular geometries on the flow patterns for a water-nhexane (where n-hexane was organic phase and water was aqueous phase) system in glass microchannels (T-junctions). Slug flow in dripping regime was observed. The flow patterns remain same with increase in size for same flow velocities but effect the transport properties which will be discussed in Section 3. Kashid and KiwiMinsker [24] studied the effect of flow velocities with T-junctions of different shapes like square and trapezoidal for variation of flow velocities from 20 to $150 \mathrm{~mm} / \mathrm{s}$. For velocities up to $250 \mathrm{~mm} / \mathrm{s}$ slug flow was observed while for velocities up to $500 \mathrm{~mm} / \mathrm{s}$ slug-drop flow was observed. Further, from 500 to $1100 \mathrm{~mm} / \mathrm{s}$ deformed-interface flow was observed while for $1200 \mathrm{~mm} / \mathrm{s}$ to $2000 \mathrm{~mm} / \mathrm{s}$ parallel flow was observed. While the flow patterns were same for both shapes the effect on transport properties were better in square than trapezoidal shapes. Further, the authors performed studies in caterpillar microchannels which gave flow patterns like slug flow, slug-dispersed flow and dispersed flow and gave very good results as far as transport properties are concerned.

Kashid and Kiwi-Minsker [24] carried out experimental investigations in 4 different types of geometries namely T-square, Trapezoidal, Y-rectangular, Concentric microchannels. The authors observed that hydraulic diameter of the microchannels and volume fraction of the dispersed phase plays an important role in addition to dimentionless numbers.

Tsaoulidis et al. [31], carried out experimental investigations on $0.2 \mathrm{~mm}$ and $0.27 \mathrm{~mm}$ micro-channels with two different materials glass and Teflon. Further, the authors used Ionic Liquids (IL) as the dispersed phase and found 3 distinct flow patterns namely annular, plug and drop flow.

\section{The Role of Fluid Properties}

Sugiura et al. [32] have considered tri-olein water system. They observed that the droplet diameter was independent of surface tension $(\sigma=3.6$ to $17.5 \mathrm{mN} / \mathrm{m})$ for lower flow velocity ranges. Yagodnitsyana et al. [29] carried out experimental studies of Ionic Liquid (IL) (1-Butyl-3Methyl-imidazolium bis (trifluoromethylsulfonyl)amide)—Water. The authors found a relation between plug velocity (plug as defined by Kovalev et al. [4]) and bulk velocity. $U_{\text {plug }}=2.34 U_{b u l k}^{1.087}$. The authors investigated the influence of bulk velocity on plug lengths and found that plug length increased with flowrate ratio increase while decreased with increase in bulk flow.

Yagodnitsyna et al. [30] carried out investigations in a T-shaped microchannel using 3 sets of LL systems: Kerosene-water; paraffin-oil—water; castor-oil—water. The authors obseved different flow patterns like rivulet flow instead of annular flow due to the wettability at the walls by the liquids of systems investigated. Serpentile flow was observed for higher Weber numbers. The authors concluded that flow pattern maps were different for different fluidic systems. Further, absence of abundant information on influence of parameters like density, viscosity, surface tension, contact angle on flow patterns were highlighted by the authors. Most research works used systems where one of the liquids did not wet the fluid walls. The authors concluded that rivulets had less velocities than plugs based on a relation between velocity of plugs and bulk velocities. For the systems considered the relation was $U_{p l u g}=1.21 U_{b u l k}$. Further, the circulations grow linearly with plug velocity.

Viscosity of both phases play an important role in flow patterns both in the continuous and dispersed phases (velocities inside droplets, slugs/plugs). Su et al. [23] found that when dispersed phase viscosities are higher than continuous phase viscosities, faster flow transition took place from slug flow to parallel flow and resulted in smaller slugs. Kovalev et al. [8] carried out experimental investigations in T-junctions. Effects of continuous phase viscosity on water slug lengths have been studied for very low capillary number $\left(2.32 \times 10^{-3}-2.32 \times 10^{-2}\right)$ by Garstecki et al. [33]. They observed marginal change in the slug length with an increase in silicon oil viscosity from $10 \mathrm{mPas}$ to $100 \mathrm{mPas}$. 
Kovalev et al. [8] found different flow patterns for low viscosity ratios upto 0.001 . The six distinct flow patterns were Plug flow, plug flow with suspended particles, droplet flow, throat annular flow, parallel flow and slug flow (Figure 8). The definition of slug flow (as defined by the authors) is different than the definition of literature works. Here slug flow is periodical flow of dispersed phase segments which have assymetrical shapes and wet at least one channel wall (as shown in Figure 8). According to the authors the plug flow is the one which have diameter and length little less than the hydraulic diameter of column. Further, the authors defined dropet flow as flow of almost spherical droplets. Interesting features of plug flows have been reported by the authors (a) The plugs took different shapes bullet like, dumble like shape with possibility of microdroplet breakoff. (b) The velocity distribution inside the plugs were found to be three dimensional in nature in contrast to two dimensional nature generally observed. (c) Flow structures evolved downstream in contrast to that observed in literature. (d) Velocity distribution in plug-plug interface was closely associated with each other. Dimensionless parameters (product of flow ratio and Capillary number) were defined to define the plug flow.

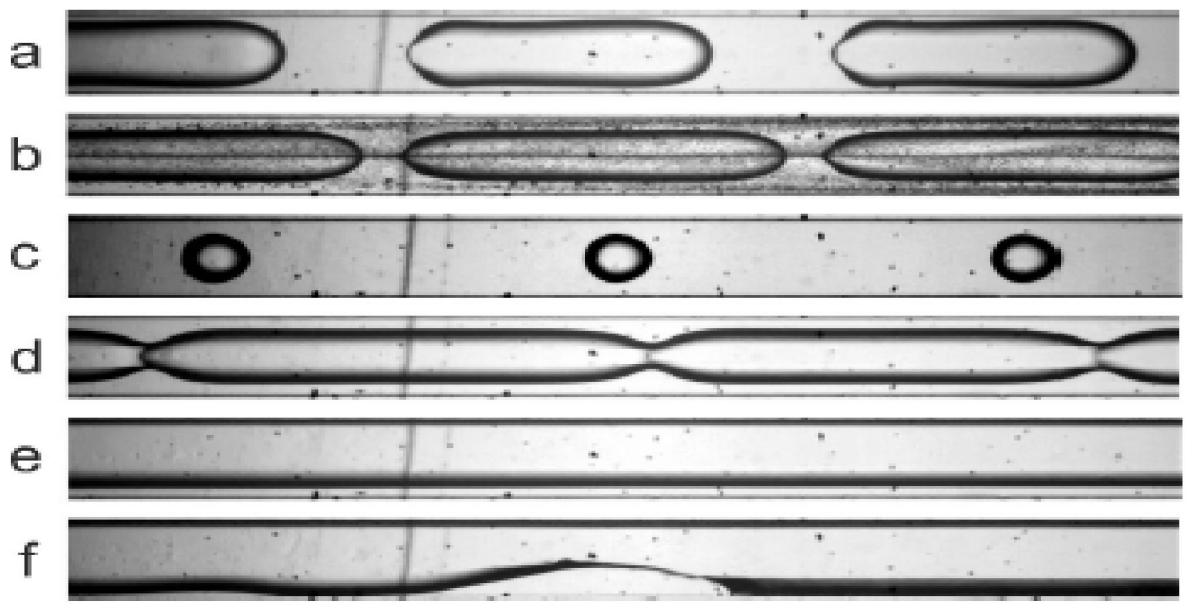

Figure 8. Flow patterns of castoroil-water system with permission from Kovalev et al. [8]. (a) Plug flow (b) plug flow with suspended particles (c) droplet flow (d) throat-annular flow (e) parallel flow (f) slug flow.

Figure 9 shows how plugs and slugs are distinguished according to their lengths as observed by Foroughi and Kawaji, [34]. If average length of the water segments was equal to or less than 5 channel diameters the flow was classified as slug flow. The author have kept the dispersed phase flow rate constant while increasing the flow rate of continuous phase. With increase in continuous phase flow the flow patterns changed from drop to plug to slug. With further increase in water flow sausage shaped annular patterns were noticed. With highest flow rates, water droplets surrounding the oil core were observed.

The authors developed a correlation for slug length as a function of flow ratio and capillary number and also related plug velocity as a function of bulk velocity. Vansteene et al. [26], carried out experimental investigations in in $\mathrm{T}$ and $\mathrm{Y}$ junctions in glass microchannels in the dripping regime. The authors developed an empirical correlation for normalized droplet diameter (NDD) for high viscosity ratios. NDD was a function of flow ratio and capillary numbers. The empirical model was found to control flow parameters as a means for optimization of droplet production frequency and specific interfacial area. 


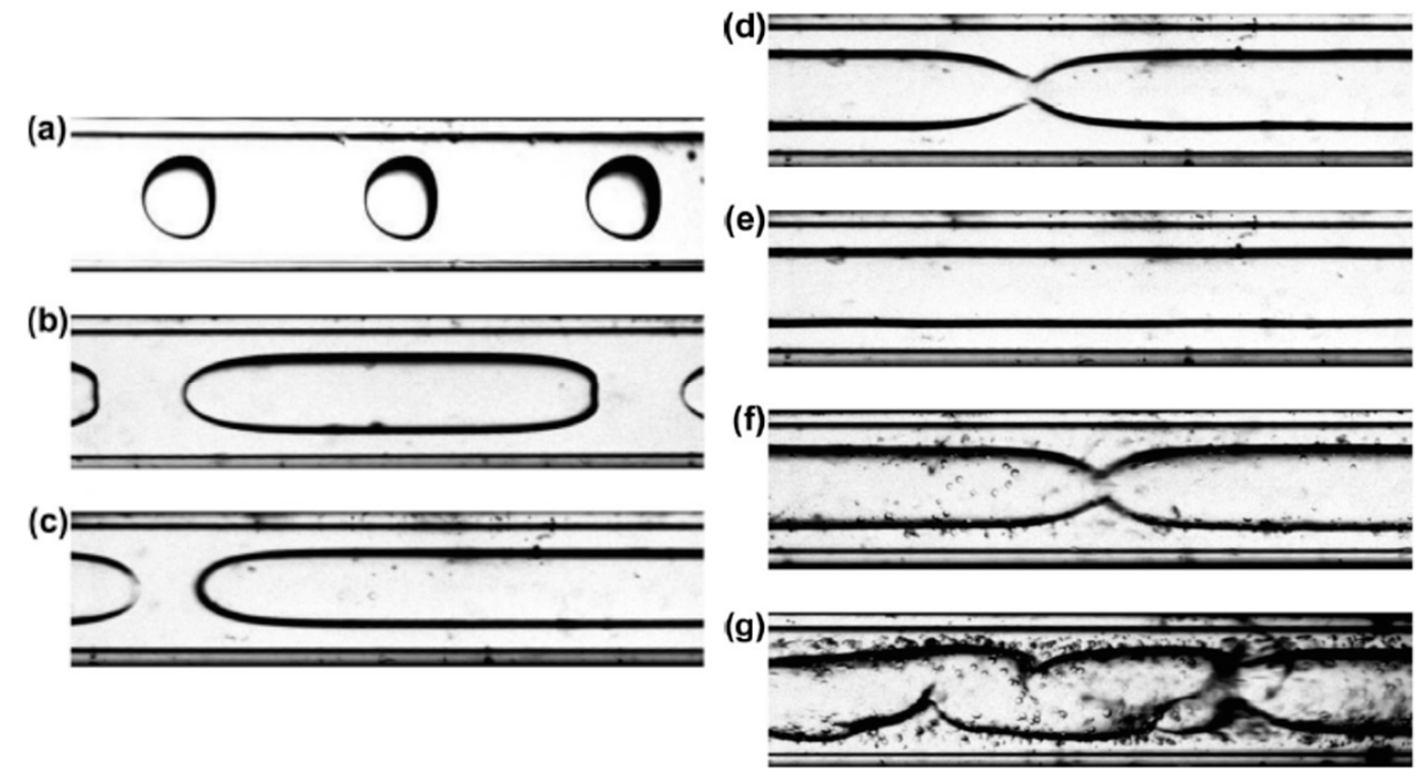

Figure 9. Flow patterns observed in viscous oil-water flow (a) droplet flow (b) plug flow (c) slug flow (d) and (e) annular flow with sausage shaped interfacial deformations (f) annular droplet flow with smooth interface (g) annular droplet flow with wavy interface (Foroughi and Kawaji, [34]). Reproduced with permission from authors.

Internal Circulations Inside Slugs/Plugs, Droplets Using Velocimetry Techniques

Internal circulations play an important role in enhancement of transport properties and reaction rates [30].

Kovalev et al. [8] used Particle Tracking Velocimetry (PTV) to understand the hydrodynamics inside plugs. The authors found important findings that the particle distribution inside plugs were different than the results obtained from flow visualization specifically the dumble like interface shapes at high plug velocities (Figure 9).

The flow inside the plugs were essentially found to be three dimensional than the two dimensional flows often reported in literature. Further, internal circulations inside the slugs (dispersed phase) as well as outside the slugs (continuous phase in between two slugs) have been studied using $\mu$-PIV (as seen in Figure 10).

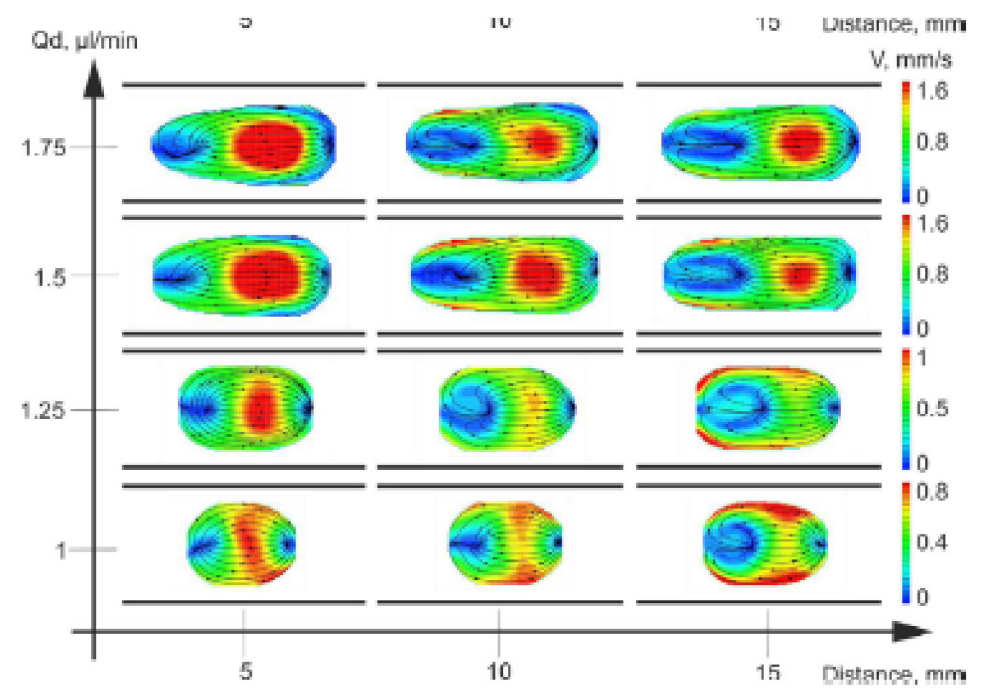

Figure 10. Plug shapes and flow structure at $5 \mathrm{~mm}, 10 \mathrm{~mm}$ and $15 \mathrm{~mm}$ from T-junction from castor oil flow rate $\mathrm{Q}=3 \mu \mathrm{L} / \mathrm{min}$ and several flowrates of water. Reproduced with permission from authors. 
Li et al. [28] have studied internal flow in droplets for varying Bond numbers $(0.003<\mathrm{Bo}<0.007)$ and Capillary numbers $\left(4.05 \times 10^{-4}<\mathrm{Ca}<1.62 \times 10^{-4}\right)$ to see the effect of viscosity ratio and flow on droplet size and droplet spacing and in turn on internal circulations. The authors used $\mu$-PIV in their investigations. The investigations were based on dimensionless droplet size (ratio of droplet length to inlet channel width) and droplet spacing (ratio of distance between two droplets to inlet channel width).

Effect of Droplet Spacing on Internal Circulations

At low inlet flowrates of the continuous and dispersed phases, the authors observed very low velocities in the region between the droplets and having reverse circulations. As the flow rates increased the circulation velocities dissapeared with an increase in droplet spacing. The influence of the wall on droplet movement was found to decrease with an increase in droplet spacing.

\section{Effect of Viscosity Ratio on Internal Circulations}

Li et al. [28] observed the effect of viscosity ratio on the internal circulations inside droplets. For lowest flowrate of their investigation, $\mathrm{Ca}=2.43 \times 10^{-5}$; a single clockwise eddy was observed in the upper part of the droplet while for highest flowrate, $\mathrm{Ca}=9.71 \times 10^{-4}$; two clockwise eddies were observed at the upper part of the droplet. The authors clarified this due to the increase in the shear stress between the droplets and dispersed phase when continuous phase velocity decreases. This makes movement of droplets in continuous phase difficult and the droplets are dragged by the continuous phase resulting in higher internal circulations.

\section{Effect of Droplet Size}

Li et al. [28] observed that when the droplet size is same as the channel width two counter rotating eddies are observed on either side of the droplet while when it is 1.5 times the channel width, the four eddies are observed with zero velocities at the core of the eddies.

\section{Effect of Curved Channels on Internal Circulations}

Liu et al. [35] studied the internal flow fields in droplets, eddy dynamics behind droplets in curved channels to study the effect of $\mathrm{Ca}$, viscosity ratio, droplet size, channel curvature and interfacial tension (by addition of surfactants). The authors observed that the above parameters except Capillary number reduced oil film gap resulting in dissapearance of eddies behind droplets. The internal circulations reduce from two circulations to single circulation with decrease in droplet size.

\section{Effect of Flow Ratio}

Garstecki et al. [33] also investigated the effect of flow ratio on slug flow formation mechanism and slug length. It was found that for flow ratio $(q<1)$ there was a marginal effect on slug length. However, for higher values of flow ratios $(q>1)$ slug lengths were found to increase. The flow ratio, was found to be an important parameter in transition of slug detachment mechanism. Flow ratio variation is an important parameter for impacting the transport properties like mass transfer coefficients. Due to increase in slug length by increase in flow ratio the transport properties like volumetric mass transfer coefficients are affected due to increase in interfacial area. This will be explained in greater detail in Section 3.

\section{Role of Surfactants}

Svensson et al. [25] found the effect of surfactants to two phase flows in square glass microchannels. They reported that the surfactant molecules adsorb on the glass wall hindering the flow between the organic phase slugs and the channel wall. This increases the resistance and effects the transport properties (specifically mass transfer). However, some authors have reported improvement in transport properties which will be discussed 
in Section 3. It is reported that the presence of surfactants enhance transport properties by 1.44 times.

Role of Vacuum at Microchannel Outlet

Parallel flow has received lesser importance due to its transition to slug flow. Recently, Li et al. [27], performed experiments to investigate stable parallel flows for $\operatorname{Re}<0.01$. The authors used Y microchannels and applied vacuum at the outlet to have stable parallel flow. The authors showed that the stability of parallel flow was due to the reduction in fluid-solid interaction at the walls due to application of vacuum. Most importantly, no surface modifications, additional channel structures or surfactants were required to get stable parallel flows in contrast to earlier works. The authors also observed transition of flow patterns by changing the inlet pressures of aqueous (water) and organic (oil) phases. The authors reported that when inlet pressure of water phase $\left(P_{i n, w}\right)$ was much higher than that of oil phase $\left(P_{i n, o}\right)$. When $P_{i n, o}$ was higher than $P_{i n, w}$ droplet flow was observed. When $P_{i n, o}$ was further increased, parallel flow was observed while for much higher inlet pressures single phase oil flow was observed.

\subsubsection{Flow Regimes and Regime Maps}

Flow regimes are maps which determine the type of flow by taking into account the various parameters like geometric, dynamic and fluid properties. Researchers, [11,15] have used plots of continuous $\mathrm{v} / \mathrm{s}$ dispersed phase velocities or dimensionless numbers (product of Weber and Ohnesorge numbers or Weber vs Capillary numbers) for continuous and dispersed phases plotted against each other to define regime maps (Figure 11A,B). The regime maps based on the domination of different forces have also been shown (Figure 11C,D). Finally, Figure 11E shows a generalized regime map which compares the data by various authors. The final regime map considers LLE systems which have a transfer component unlike other regime maps which are just two phase LL systems. Interestingly, Yagodnitsyna et al. [7] observed different flow regimes than the regular flow regimes reported by other authors.

Yagodnitsyna et al. [7] carried out dimensionless analysis to find that the regimes depended on two dimensionless number Weber number and Ohnesorge number with the relation $W e^{\varepsilon / 2} * O h^{\beta / 2}$. The data showed that $\varepsilon=2$ and $\beta=1$. By plotting the dimensionless number relation for continuous $\mathrm{v} / \mathrm{s}$ dispersed phase Yagodnitsyna et al. [7] plotted a universal regime map (Figure 11A) for main channels. The map consists of Weber number times Ohnesorge number for dispersed phase as its ordinate while Weber number times Ohnesorge number for continuous phase is its abscissa. The map covers all the flow regimes of the main channels namely parallel, plug, slug, droplet, rivulet, serpentine flows. The authors claim that this map can predict the flow regimes for any type of system and flow in micro-channels. The authors have presented their data as well as the data from Zhao et al. [16] for this regime map. Similarly, for micro-channel junctions (T and cross $\mathrm{T}$ junctions), Wu et al. [11] have predicted the flow patterns as shown in Figure 11B. The regime map is plotted with Weber number of continuous phase $\left(W e_{c}\right)$ as its ordinate while Capillary number for dispersed phase as its abscissa. The regime map (Figure 11B) shows the transition lines of tubing-threading, dripping and dripping jetting with good predictive accuracy. However, physical properties have not been accurately captured in this regime map. 

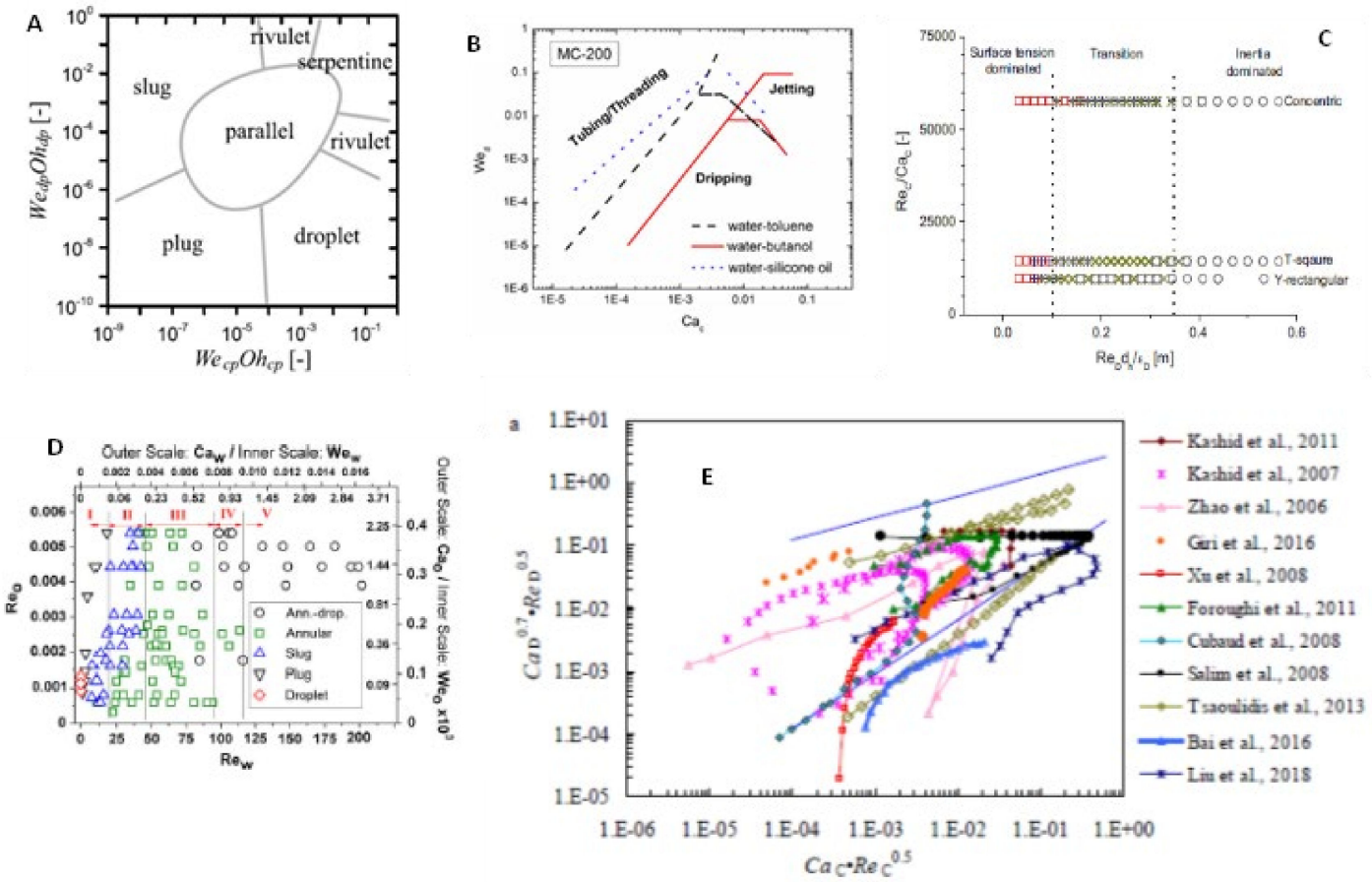

Figure 11. (A) Regime map of Yagodnitsyna et al. [7]; (B) Regime map of Wu et al. [11]; (C) Regime map by Kashid and Kiwi-Minsker [24]; $\square$ slug flow; ${ }^{+}$slug-drop; $\times$deformed interface; ${ }^{\circ}$ parallel-annular (D) Flow pattern map for silicon oil water flow initially saturated with oil. Foroughi and Kawaji [34] (E) Regime map proposed by Zhang et al. [12]. Reproduced with permission from authors.

Zhang et al. [12] carried out experimental investigations for flow patterns and mass transfer using Toluene-water; toluene-sulfuric acid and ethylacetate-water systems. The authors also carried out measurements to study the effect of temperature on the performance of micro-channels for the different systems. The fluid systems were chosen so that they could simulate reacting processes like nitration, sulfonation and acid catalysed reactions and have different fluid properties enabling parametric studies. The authors observed a lot of change in mixing behaviour for the operating range considered. Composite flow regime maps (Figure 11E) were presented in the form of $\mathrm{Ca}_{\mathrm{c}} \operatorname{Re}_{\mathrm{c}}{ }^{0.5} \mathrm{v} / \mathrm{s} \mathrm{Ca}_{\mathrm{D}}{ }^{0.7} \mathrm{Re}_{\mathrm{D}}{ }^{0.5}$. The experimental data as well as data from literature was compared with the regime map and good prediction of flow patterns was found.

\subsubsection{Studies in Pressure Drop in Microchannels}

In this section, we present single and two phase pressure drops in the form of measurements and analytical models predicted by different authors [31,36-38]. Table 2 explain the studies of pressure drop. Studies in pressure drops have been extensively covered in detail in review by Al-Azzawi et al. [5]. Hence, we try to cover this section briefly.

Experimental measurements of single phase pressure drops in micro-channels were carried out for 3 liquid mixtures $\mathrm{Fu}$, [36]. The investigations were carried out for uniform, converging and diverging sections considering the $\mathrm{T}$ and $\mathrm{Y}$ junctions that are present in all micro-channel systems. The authors observed a linear relationship between pressure drop and volumetric flow rates for uniform, converging and diverging micro-channels. The maximum pressure drops were highest for diverging Y micro-channels ( 100 kPa).

Kashid and Agar, [38] carried out two phase pressure drop measurements in Y-junction micro-channels for a set of different flow velocities in slug flow regime. The system chosen was Water-cyclohexane. The total pressure drop was given by the sum of hydrodynamic and capillary pressure drop. The hydrodynamic pressure drop was given by the Hagen Poiseuille equation while the capillary pressure drop was given by Young Laplace equation. The analytical model equation for total pressure drop of the main channel are given 
in Table 2. The pressure drop is a summation of individual pressure drops of water and cyclohexane multiplied by its volume fraction. As per our earlier discussion, it has been observed that various researchers have found film formation in these type of microchannels. Hence, the authors applied two approaches for pressure drop, one with film and one without film. The variation of pressure drop was carried out with different parameters like inlet flow rate, flow ratio and slug flow velocity.

Su et al. [23] carried out experimental investigations of pressure drop in microchannels and observed that hydrodynamics was characterized by Poiseulle number which is product of friction factor and Reynolds number (Re). Pressure drop was investigated with single phase fluid flow with different viscosities. The authors concluded that conventional theory could predict the pressure drop in microchannels with good accuracy.

Tsaoulidis et al. [31] carried out measurements for the two phase pressure drop for different volume fractions of IL and compared it with the single phase IL pressure drop. The authors found that the two phase pressure drop was always higher than the single phase pressure drop of IL with identical flowrates considered for comparison. Further, the two phase pressure drop increases with increase in volume fraction of IL. The trend of pressure drop however depended on material of construction of the channels. When glass micro-channels were used it was observed that at lower flow rates the two phase pressure drop was lower than the single phase pressure drop. Authors used the correlation by Jovanović et al. [39] for comparison with their measured values.

Ladosz and von Rohr [37] proposed two models to calculate pressure drop of liquidliquid slug flow in square micro-channels. Two different models for pressure drop were proposed (a) Moving film model and (b) no film model. The authors approximated a droplet surrounded by liquid film as annular flow for modelling the slug flow in the presence of film. The authors found good agreement of both models with toluene water system while for silicon-Oil-water system poor agreement was obtained. Pressure drop for two channel widths $(0.2 \mathrm{~mm}$ and $0.4 \mathrm{~mm}$ ) were measured and the analytical model developed (Table 2) was validated. The authors found good agreement for two phase measurements with water-toluene system while with silicon-Oil-water system poor agreement was observed. 
Table 2. Literature of studies of pressure drop in micro-channels for two phase systems.

\begin{tabular}{|c|c|c|c|c|c|c|c|c|c|c|c|c|}
\hline \multirow[t]{2}{*}{ Authors } & \multicolumn{4}{|c|}{ Channel (CH) Details } & \multirow[b]{2}{*}{$\begin{array}{c}\text { Flow } \\
\text { Rate/Velocity } \\
(\mathrm{m} / \mathrm{s})\end{array}$} & \multirow[b]{2}{*}{ System } & \multirow[b]{2}{*}{$\begin{array}{l}\text { Parameters } \\
\text { Varied }\end{array}$} & \multirow[b]{2}{*}{$\begin{array}{l}\text { Magnitudes } \\
\text { of } \Delta \mathrm{P} \text { for Re } \\
\text { Ranges }\end{array}$} & \multirow[b]{2}{*}{ Assumptions } & \multirow[b]{2}{*}{ Limitations } & \multirow[b]{2}{*}{ s Findings } & \multirow[b]{2}{*}{ Correlations } \\
\hline & $\begin{array}{c}\text { Geometry } \\
\text { Type }\end{array}$ & $\begin{array}{l}\text { CH Diame- } \\
\text { ter/Size } \\
(\mathrm{mm})\end{array}$ & $\begin{array}{l}\text { CH Length } \\
(\mathrm{mm})\end{array}$ & $\begin{array}{c}\mathrm{CH} \\
\text { Material }\end{array}$ & & & & & & & & \\
\hline $\begin{array}{c}\text { Foroughi } \\
\text { and } \\
\text { Kawaji, } \\
{[34]}\end{array}$ & $\begin{array}{l}\text { Circular mi- } \\
\text { crochannel }\end{array}$ & 0.25 & 700 & $\begin{array}{l}\text { Fused } \\
\text { Silica }\end{array}$ & $\begin{array}{c}\text { 1. } 0.05<\mathrm{v}_{\mathrm{W}}< \\
0.75 \text { for } \\
0.0139<\mathrm{v}_{\mathrm{O}}< \\
0.017 ; 2 . \\
0.025<\mathrm{v}_{\mathrm{W}}< \\
0.48 \text { for } 0.057 \\
<\mathrm{v}_{\mathrm{o}}<0.0109 ;\end{array}$ & $\begin{array}{l}\text { Siliconoil- } \\
\text { Water }\end{array}$ & $\begin{array}{l}\text { Superficial } \\
\text { water and oil } \\
\text { velocity }\end{array}$ & $\begin{array}{c}1.10000< \\
\Delta \mathrm{P} / \mathrm{L}< \\
29000 ; \\
2.4000< \\
\Delta \mathrm{P} / \mathrm{L}< \\
17000\end{array}$ & $4,5,6$ & & 15,16 & $\begin{array}{c}\quad\left(\frac{\Delta P}{L}\right)_{T P}=C_{3} V_{w}+C_{4} \\
\text { where } C 3=27646 ; C 4567,343\end{array}$ \\
\hline $\begin{array}{l}\text { Tsaoulidis } \\
\text { et al. [31] }\end{array}$ & $\begin{array}{c}\mathrm{T} \text { and Y } \\
\text { junction } \\
\text { micro- } \\
\text { capillaries }\end{array}$ & $0.2-0.27$ & 50 & $\begin{array}{l}\text { Teflon, } \\
\text { Glass }\end{array}$ & $\begin{array}{c}0.065-214.9 \\
\mathrm{~cm}^{3} / \mathrm{h}\end{array}$ & $\begin{array}{l}\text { Water-ionic- } \\
\text { liquid }\end{array}$ & $\begin{array}{l}\text { Ionic liquid } \\
\text { volume } \\
\text { fraction }\end{array}$ & $\begin{array}{c}0.1<\operatorname{Re}<0.4 \\
30 \leq \Delta \mathrm{P} \leq \\
175\end{array}$ & 4 & 1 & $5,6,7,8$ & $\begin{array}{c}\Delta P= \\
\frac{L}{L_{U}}\left(\frac{8 \mu_{0} U_{\text {plug }} a L}{\left(R-h_{\text {film }}\right)^{2}}+\frac{8 \mu_{c} U_{m i x}(1-\alpha) L}{R^{2}}\right) \\
+\frac{L}{L_{h}} \frac{\sigma}{d} C(3 C a)^{\frac{2}{3}} \\
\alpha=\left(\frac{L_{p l u g}}{l_{U}}\right) \\
\frac{h_{\text {film }}}{R}=0.3\left(1-e^{-6.9 C a^{0.54}}\right)\end{array}$ \\
\hline $\begin{array}{l}\text { Jovanovic } \\
\text { et al. [39] }\end{array}$ & $\begin{array}{l}\text { Round micro- } \\
\text { capillaries } \\
\text { Y-mixer }\end{array}$ & $0.248,0.498$ & 1000 & $\begin{array}{c}\text { Fused } \\
\text { silica }\end{array}$ & $\begin{array}{c}0.05-6 \\
\mathrm{~mL} / \mathrm{min}\end{array}$ & $\begin{array}{c}\text { (40\%Ethylene } \\
\text { Glycol)- } \\
\text { water- } \\
\text { toluene }\end{array}$ & Flow rate & $\begin{array}{c}10<\operatorname{Re}<150 \\
1000 \leq \Delta \mathrm{P} \leq \\
10000\end{array}$ & 4 & 1 & $17,18,19$ & $\begin{array}{c}\Delta P= \\
\frac{L}{L_{U}}\left(\frac{8 \mu_{0} U_{\text {plug }} a L}{\left(R-h_{\text {film }}\right)^{2}}+\frac{8 \mu_{c} U_{m i x}(1-\alpha) L}{R^{2}}\right) \\
+\frac{L}{L_{h}} \frac{\sigma}{d} C(3 C a)^{\frac{2}{3}} \\
\alpha=\left(\frac{L_{p l u g}}{l_{U}}\right) \text { and } \\
h_{f i l m}=1.3 \mathrm{Ca}^{\frac{2}{3}}\end{array}$ \\
\hline $\mathrm{Fu}[36]$ & $\begin{array}{c}\text { Y shaped } \\
\text { Rectangular } \\
\text { microchan- } \\
\text { nel }\end{array}$ & $\begin{array}{l}\text { Hydraulic } \\
\text { dia }=0.174\end{array}$ & 20 & PTFE & $\begin{array}{l}4.8-62.3 \\
\mathrm{~mm}^{3} / \mathrm{h}\end{array}$ & $\begin{array}{c}\text { Sulphuric } \\
\text { acid-sodium } \\
\text { bi-carbonate } \\
\text { or water }\end{array}$ & $\begin{array}{c}\text { Flow rate; } \\
\text { flow velocity }\end{array}$ & $\begin{array}{c}18<\operatorname{Re}<114 \\
6 \leq \Delta \mathrm{P} \leq 30\end{array}$ & 5 & 2 & 3,4 & $\begin{array}{c}\Delta P= \\
\Delta P_{f}+\frac{1}{2} \rho\left(v_{\text {out }}^{2}+v_{\text {in }}^{2}\right)+\frac{k}{2} \rho v^{2}\end{array}$ \\
\hline
\end{tabular}


Table 2. Cont.

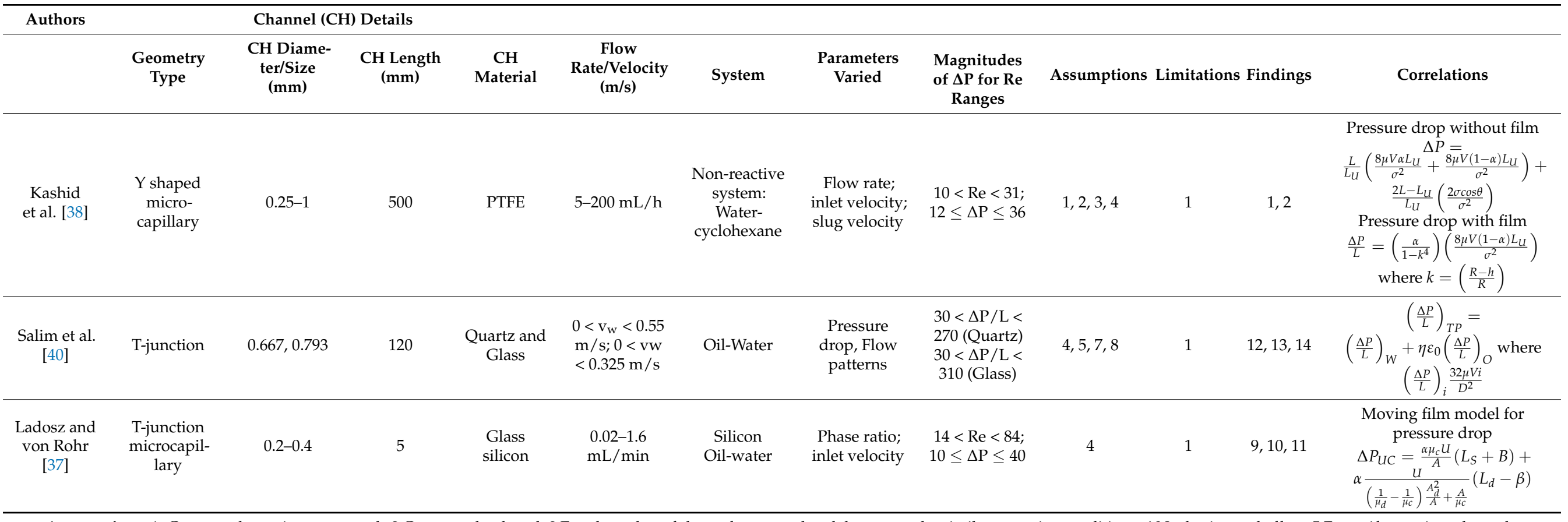

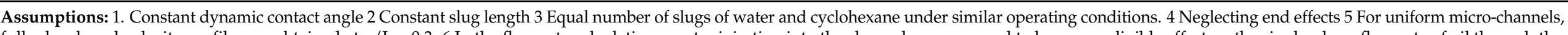

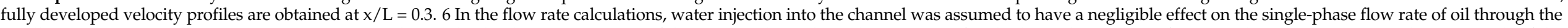

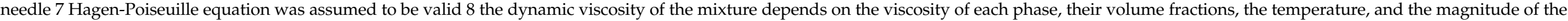

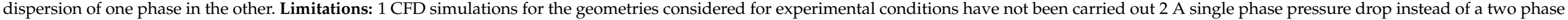

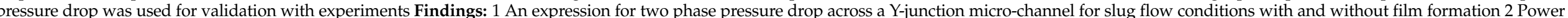

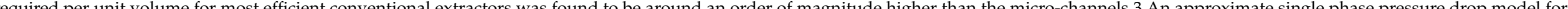
in

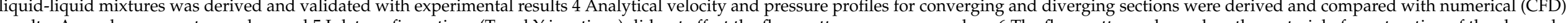

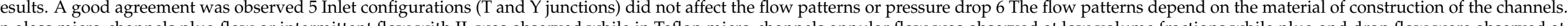

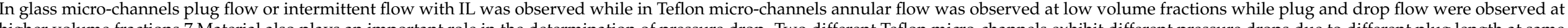

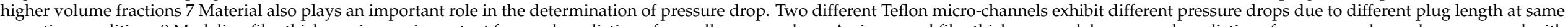

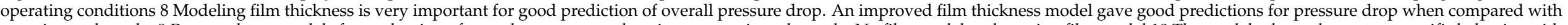

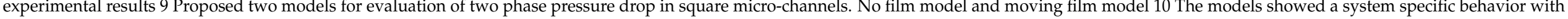

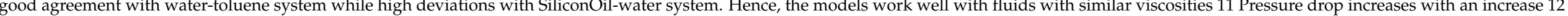

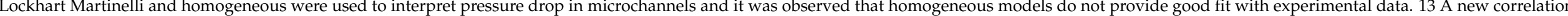

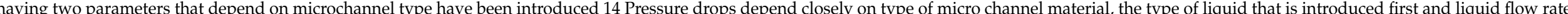

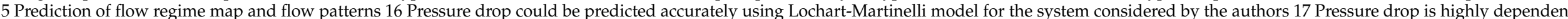
on slug size $18 \mathrm{It}$ is important to correctly measure interfacial pressure drop 19 Film velocity has negligible influence on pressure drop. 
The authors attributed this to lower film thickness of the film than the one assumed for analytical model development [41]. For both systems considered there was an increase of pressure drop with flow rate for both channels. For example, for silicon-oil-water system, the pressure drop increased from 50 to $330 \mathrm{kPa}$ for corresponding inlet velocities of $0.01 \mathrm{~m} / \mathrm{s}$ and $0.14 \mathrm{~m} / \mathrm{s}$ for $0.2 \mathrm{~mm}$ channel diameters, the increase was restricted from 10 to $60 \mathrm{kPa}$ for corresponding inlet velocities of $0.01 \mathrm{~m} / \mathrm{s}$ and $0.14 \mathrm{~m} / \mathrm{s}$ for $0.4 \mathrm{~mm}$ channel diameters. Similarly values for toluene-water systems for pressure drop were 30 and $225 \mathrm{kPa}$ for velocities of 0.02 and $0.27 \mathrm{~m} / \mathrm{s}$ respectively for $0.2 \mathrm{~mm}$ channel diameters and 5 and 30 for $0.4 \mathrm{~mm}$ channel diameters.

Studies on two phase pressure drop carried by authors $[37,38]$ show the following findings:

1. Two phase pressure drops involve hydrodynamic and interfacial/capillary pressure drops in microchannels

2. Both experimental investigations and analytical models show that two phase pressure drop is higher than single phase pressure drop

3. Modelling two phase pressure drop involves careful consideration of two aspects (a) film near the wall and (b) the movement of the film

4. Two phase pressure drop depends on (i) the fluids/system under consideration (ii) volume fraction of dispersed phase (iii) material of construction of capillaries.

Most of the points mentioned above have been considered by the researchers [37] but the model presented by the authors is valid only for fluids with similar viscosities and show large deviations for fluids with large viscosity differences.

Figure $12 \mathrm{~A}-\mathrm{C}$ shows the experimental data of variation of single/two phase pressure drops w.r.t Re for different authors. Figure 12A shows the variation of pressure drop as a function of $\operatorname{Re}(5 \leq \operatorname{Re} \leq 120)$ for water as working fluid. The channel diameter is $675 \mu \mathrm{m}$. A linear relationship is observed. The pressure drop values range from $5 \mathrm{kPa}$ to $100 \mathrm{kPa}$ respectively. Figure 12B shows the two pressure drop variation with respect to Reynolds numbers. Systems with similar viscosities have been considered. Channel diameters range from 400 to $500 \mu \mathrm{m}$ respectively. It can be observed that the measured pressure drops for [37-39] are similar till $\mathrm{Re}=40$ while deviations upto $50 \%$ between measurements of $[37,39]$ are observed after that. Deviations upto $50 \%$ can be observed. Probable reasons are the type of junction being used and the difference in channel diameter magnitudes. Figure 12C shows the pressure drop of Water-IL system by Tsaoulidis et al. [31]. The Re is below 0.5 due to high viscosities of IL. The pressure drops are however higher ranging from 20 to $180 \mathrm{kPa}$. The researchers have validated their data with respective models as shown in Table 2. Deviations of 10-20\% have been shown by the authors for their respective models. The pressure drop mode1 Jovanović et al. [39] was compared with another pressure drop model of Kashid and Agar [38] and found that the latter over-predicted the experimental data of former. Tsaoulidis et al. [31] have used both $\mathrm{T}$ and $\mathrm{Y}$ junctions but at very low Reynolds numbers. They have also developed their own model which was seen to show good agreement with experimental data with deviations of around $10 \%$.

\subsection{CFD Studies}

The CFD studies in LL systems have been focused on flow patterns, namely, slug flow, parallel flow and transition flow. The effect of operating parameters has also been shown by Raj et al. [42]. However, as per Raj et al. [42], some flow patterns which were observed in experiments could not be reproduced in their 3D simulations. Pressure drops using two phase CFD simulations have not been reported based on the simulation results in the literature. 

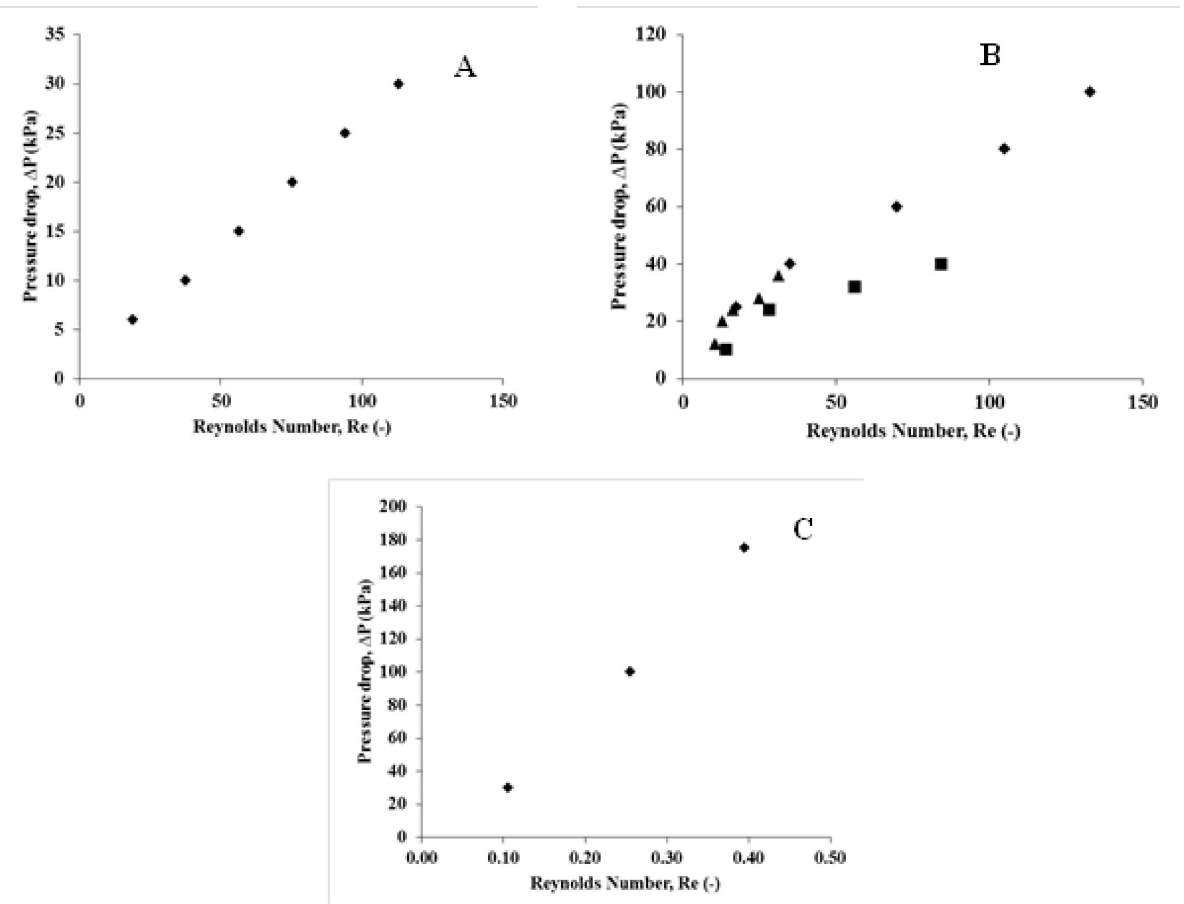

Figure 12. Pressure-drop variation with Reynolds number for equal flow rates of both phase liquids (A) Single phase system with water as fluid and diameter $675 \mu \mathrm{m}$ (B) Two phase systems $\boldsymbol{\Delta}$ WaterCyclohexane system in Y-junction micro-channel of diameter $500 \mu \mathrm{m}$ by Kashid et al. [1] WaterToluene system in $\mathrm{Y}$ junction by Jovanivić et al. [39] in $\mathrm{Y}$ junction micro-channel of diameter 498 $\mu \mathrm{m}$ Water- Toluene system by Ladosz and Rudolf von Rohr, [37] in Y junction micro-channel of diameter $400 \mu \mathrm{m}(\mathrm{C})$ Variation of pressure drop for $\mathrm{Re}<0.5$ for Water-Ionic-liquid system for channel diameter of $270 \mu \mathrm{m}$ by Tsaoulidis et al. [31].

In the upcoming subsections, different methods to handle deformable interfaces in two phase flows have been described. The studies of two systems mainly water-cyclohexane and water-toluene [14,42-44] have been presented. Tables 3 and 4 gives the CFD details of prominent research works. Different strategies to handle moving interfaces are classified into moving mesh methods, fixed mesh methods and a combination of both. In the first method, a moving mesh is used to track the interface. As the topology of the interface changes, the mesh is adjusted in accordance with the change. Methods falling under this strategy are called front tracking methods. The second approach used a fixed (Eulerian) mesh, while the interface is tracked using different procedures, e.g., special markers or functions. Such methods are called front capturing methods; they include marker-and-cell (MAC), surface capturing and volume capturing approaches.

In front tracking methods, the interface is resolved directly. It always lies between two neighbouring mesh elements. As the interface moves, the neighbouring mesh elements deform in order to track the movement of the interface. For the description of the interface movement, an additional explicit equation is necessary. Usually the latter can be derived from an integral consideration of transport phenomena around the interface. It is worth mentioning that, in front tracking methods, each phase is considered separately, by using an individual set of equations describing the flow field. The front tracking methods are extremely accurate and robust, but rather complex to implement. Difficulties arise when two additional equations are needed to describe the mesh movement in three dimensions, because the second equation cannot be readily found in terms of the physical description of the system under study.

One of the oldest methods to describe interfacial movement is the marker and cell (MAC) method (Harlow and Welch, [45]). Here, massless particles are used to capture the motion of one fluid and thus the motion of the interface. Although its implementation is 
easy and it is capable of resolving the interface accurately, it fails to describe significant deformations of the interface. This is mainly because of the necessary redistribution of the markers, due to deformation or, in case where the interface expands, the required addition of new particles. Besides, this method can be very demanding in terms of computing power and time for 3D simulations.

One of the most popular surface capturing method is the level set (LS) method [46,47]. Here, a function is used to locate the interface, which takes positive and negative values on different sides of the interface and zero at the interface. The interface is therefore called zero LS. The surface tension is modelled using the method by Brackbill et al. [48]. An overview of the different LS methods is presented by Osher and Fedkiw, [49]. This method is conceptually simple and easy to implement. Its main drawback is the loss of mass (or volume), especially for significantly deformed interfaces van sind Annaland, [50].

The volume of fluid (VOF) method introduced by Hirt and Nichols, [51] represents a typical volume capturing method. The basic idea of the VOF method is the definition of a volume function which takes values between zero and one for the cells containing the interface. 
Table 3. Experimental details used for two phase CFD works.

\begin{tabular}{|c|c|c|c|c|c|c|c|c|c|c|c|}
\hline \multirow[t]{2}{*}{ Authors } & \multicolumn{3}{|c|}{ Channel (CH) Details } & \multicolumn{3}{|c|}{ Type of Study } & \multirow[b]{2}{*}{ Flow Regime } & \multirow[t]{2}{*}{$\begin{array}{l}\text { Parameters } \\
\text { Varied }\end{array}$} & \multirow[t]{2}{*}{$\begin{array}{c}\text { Output } \\
\text { Parameters }\end{array}$} & \multirow[t]{2}{*}{ (VMTC), $1 / \mathrm{s}$} & \multirow[t]{2}{*}{$\begin{array}{c}\text { Dimensionles } \\
\text { Number }\end{array}$} \\
\hline & $\begin{array}{c}\text { Geometry } \\
\text { Type }\end{array}$ & $\begin{array}{c}\mathrm{CH} \\
\text { Diameter/Size }\end{array}$ & $\begin{array}{l}\text { CH Length } \\
(\mathrm{mm})\end{array}$ & $\begin{array}{c}\text { Flow } \\
\text { Rate/Velocity } \\
(\mathrm{m} / \mathrm{s})\end{array}$ & $\begin{array}{c}\text { Experimental } \\
\text { /CFD }\end{array}$ & System & & & & & \\
\hline $\begin{array}{c}\text { Kashid et al. } \\
\text { [52] }\end{array}$ & $\begin{array}{c}\text { Y type } \\
\text { Microchannel }\end{array}$ & Dia. $=0.5-1$ & 1 & $5-100 \mathrm{~mL} / \mathrm{h}$ & $\begin{array}{l}\text { Experimental } \\
\text { and CFD }\end{array}$ & $\begin{array}{c}\text { Water, } \\
\text { Cyclohexane }\end{array}$ & Slug flow & $\begin{array}{l}\text { Y-junction dia., } \\
\text { Capillary } \\
\text { diameter }\end{array}$ & Slug size & NA & NA \\
\hline $\begin{array}{c}\text { Kashid et al. } \\
\text { [44] }\end{array}$ & $\begin{array}{l}\text { T-type cross } \\
\text { microchannel }\end{array}$ & 0.05 & 1 & $\begin{array}{c}\text { Flow Velocity } \\
=27 \mathrm{~mm} / \mathrm{s} ; 53 \\
\mathrm{~mm} / \mathrm{s} ; 67 \\
\mathrm{~mm} / \mathrm{s}\end{array}$ & CFD & $\begin{array}{c}\text { Non-reactive } \\
\text { system: } \\
\text { Glyc- } \\
\text { erol/Water (1) } \\
\text { FC-3283/PFO } \\
\text { (2) }\end{array}$ & Slug flow & $\begin{array}{l}\text { Channel Dia., } \\
\text { Flow Velocity, } \\
\text { Channel } \\
\text { Length, time, } \\
\text { Flow velocity }\end{array}$ & $\begin{array}{c}\text { Slug Length, } \\
\text { Static Pressure, } \\
\text { Laplace } \\
\text { Pressure }\end{array}$ & NA & $\begin{array}{l}\text { Courant } \\
\text { Number, } \\
\text { Capillary } \\
\text { Number }\end{array}$ \\
\hline Raj et al. [42] & $\begin{array}{l}\text { Rectangular } \\
\text { T-Type }\end{array}$ & $\begin{array}{c}100 \times 50 \\
100 \times 100 \\
50 \times 50 \\
100 \times 50\end{array}$ & $\begin{array}{l}33 \\
33 \\
33 \\
79\end{array}$ & $\begin{array}{c}\text { Water Flow } \\
(\mu \mathrm{L} / \mathrm{s})-0.019- \\
0.417 \\
\text { Oil Flow- } \\
0.004-0.14\end{array}$ & CFD & Water, Oil & Slug flow & $\begin{array}{c}\text { Water and Oil } \\
\text { Flow, } \\
\text { Channel Size, } \\
\text { Water/oil } \\
\text { Flow, } \\
\text { time }\end{array}$ & Slug size & NA & $\begin{array}{c}\text { Capillary } \\
\text { Number, } \\
\text { Reynolds } \\
\text { Number }\end{array}$ \\
\hline
\end{tabular}

Table 4. CFD details of two phase simulations.

\begin{tabular}{|c|c|c|c|c|c|c|c|c|c|c|}
\hline Authors & & & CFD Details & & & & & $\begin{array}{l}\text { SOFTWARE } \\
\text { USED }\end{array}$ & Assumptions & Findings \\
\hline & $\begin{array}{c}\text { Single/Two } \\
\text { Phase }\end{array}$ & Dimension (D) & Grid Details & $\begin{array}{c}\text { VOF/ Levelset } \\
\text { Method }\end{array}$ & $\begin{array}{c}\text { Size of } \\
\text { Microchannel }\end{array}$ & System & Steady/Unsteady & & & \\
\hline $\begin{array}{c}\text { Kashid et al. } \\
\text { [44] }\end{array}$ & Two phase & $2 \mathrm{D}$ & $\begin{array}{c}\text { Mesh Size- } 0.5 \text { to } \\
2 \text { micrometer } \\
\text { Number of } \\
\text { cells- } 58,000\end{array}$ & VOF & & Water-Toluene & Unsteady state & $\begin{array}{l}\text { Ansys Fluent } \\
\text { Ansys GAMBIT }\end{array}$ & $1,2,3,4$ & 5 \\
\hline Raj et al. [42] & Two phase & $3 \mathrm{D}$ & $\begin{array}{l}\text { Medium Grid } \\
(72,960 \text { Cells) }\end{array}$ & VOF & & Water-Oil & Unsteady state & Ansys Fluent & $1,2,3,4$ & $6,7,8$ \\
\hline $\begin{array}{c}\text { Yamasaki et al. } \\
\text { [53] }\end{array}$ & Two phase & $3 \mathrm{D}$ & NA & VOF & $0.2 \times 0.2$ & Water-Octane & Unsteady state & $\begin{array}{l}\text { Open source } \\
\text { code Gerris }\end{array}$ & $1,2,3,4$ & \\
\hline
\end{tabular}


Table 4. Cont.

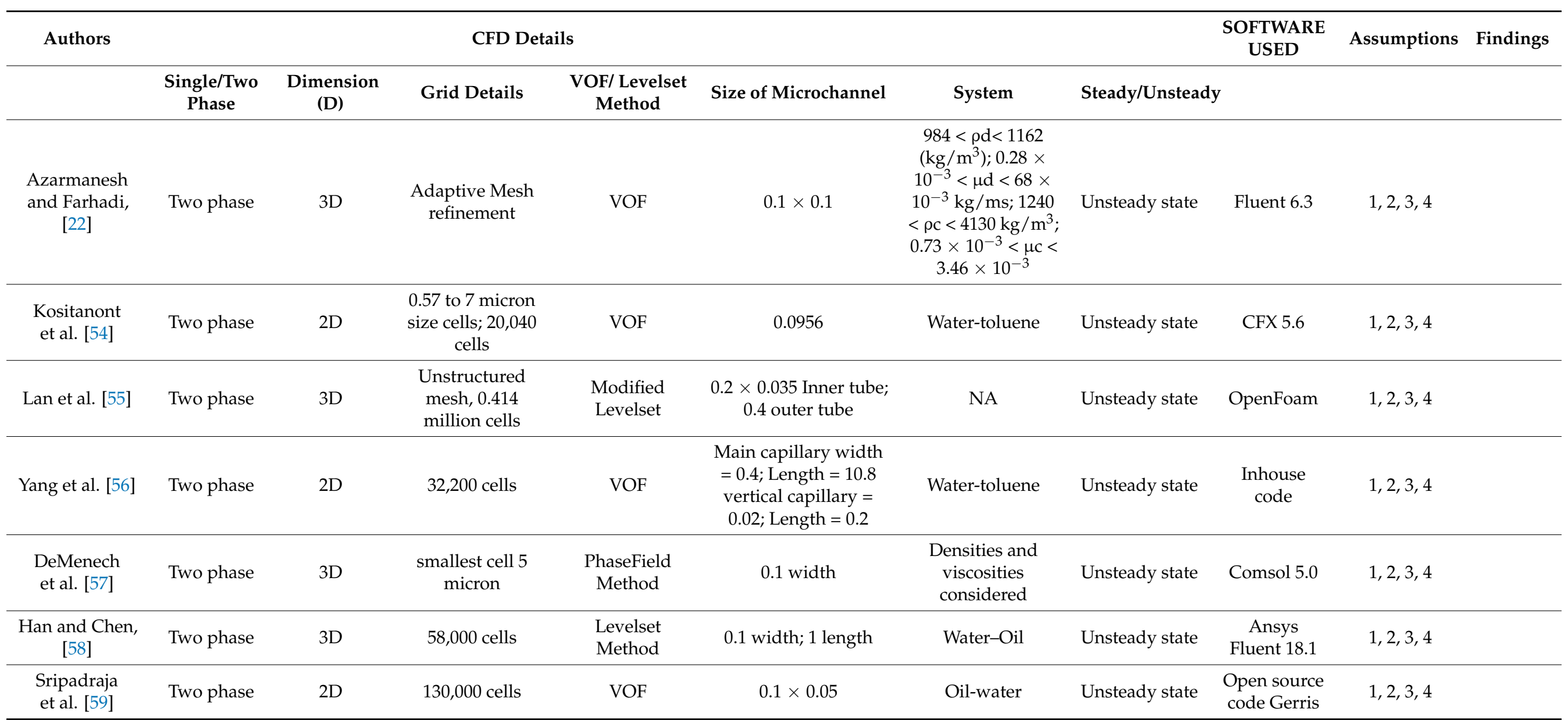

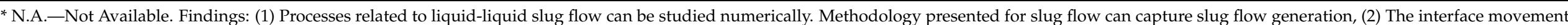

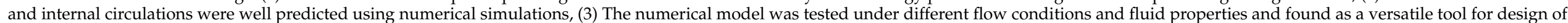

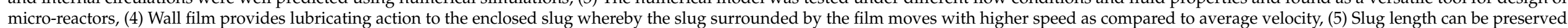

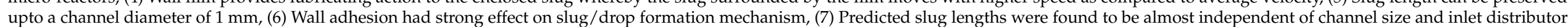

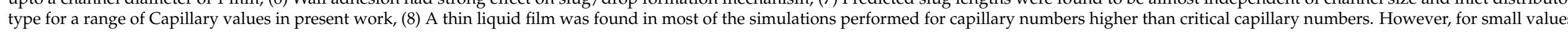

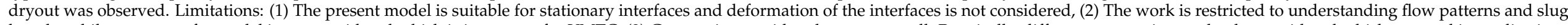

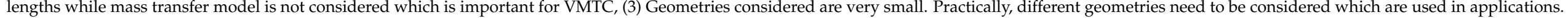
Assumptions: (1) Flow is steady, (2) Flow is fully developed, (3) Flow is Newtonian 4 Flow is incompressible and miscible with each other. 
A detailed review on the VOF methods is published by Rider and Kothe, [60]. This method is capable of handling problems with significant interface topology change and does not suffer from mass (or volume) losses. The extension of the method to 3D simulations is straightforward and no specific algorithm is needed for the case of merging or break up of the interface. However, the interface is smeared out and merges "numerically". The main drawback of this method is the inherent numerical smearing.

An alternative method is suggested by thegroup of researchers [61,62]. They used a combination of both front tracking and front capturing methods, whereby a fixed grid is used to describe the motion of the fluid flow and another moving grid with a low dimension is used to track the interface. Since for both phases a fixed grid is used, they are treated together, by solving a single set of governing equations for the whole flow field. The complexity of this method is due to the necessary dynamic remeshing of the moving sub-grid and mapping of the data coming from the moving grid to the fixed one. Additionally, for the merging and breakage of the interface, a special sub-grid algorithm is required. Most researchers have used the volume capturing (VOF) or surface capturing (LS) methods with a combination of both. The equations and boundary conditions used for VOF and Levelset equations along with continuity and momentum equations have been given below.

Continuity Equation:

$$
\nabla \cdot v=0
$$

Momentum Equation:

$$
\frac{\partial u}{\partial t}+\nabla \cdot(u u)=-\nabla p+\nabla \cdot\left[\mu\left\{\nabla \cdot v+(\nabla \cdot v)^{T}\right\}\right]+g+F
$$

where $\sigma=$ surface tension, $\kappa_{n}=$ surface curvature at the fluid interface computed from the divergence of the unit surface normal.

$F$ in the above equation is defined as:

$$
\begin{gathered}
F=-\sigma \kappa_{n}\left[\frac{\varnothing_{1} \rho_{1}+\varnothing_{2} \rho_{2}}{\frac{\rho_{1}+\rho_{1}}{2}}\right] \\
\kappa_{n}=\nabla \cdot \hat{n} \frac{1}{|n|}\left[\left(\frac{n}{|n|} \cdot \nabla\right)|n|-(\nabla \cdot n)\right] \\
\hat{n} \text { as } \hat{n}=\frac{n}{|n|}, n=\nabla \varnothing=0
\end{gathered}
$$

VOF Equation:

$$
\frac{\partial f}{\partial t}+\nabla \cdot(u f)=0
$$

Level-Set Equation

$$
\frac{\partial \varnothing}{\partial t}+\nabla \cdot(u \varnothing)=\gamma \nabla\left(-\varnothing(1-\varnothing) \frac{\Delta \varnothing}{|\Delta \varnothing|}+\varepsilon \Delta \varnothing\right)
$$

The boundary conditions used for most of the research articles considered in the present review are as follows:

1. Inlet- Velocity value

2. Wall-No slip Condition

3. Outlet-Constant Pressure

The mathematical equations used are as follows:

Inlet:

$$
\vec{v}=-v_{0} \hat{n}
$$


For no slip and zero flux:

$$
\vec{v}=0
$$

Outlet:

$$
\begin{gathered}
p=0 \\
\mu\left\{\nabla \cdot \vec{v}+(\nabla \cdot \vec{v})^{T}\right\} \cdot \hat{n}=0
\end{gathered}
$$

The parametric sensitivity carried out by various authors in the subsections below:

\subsubsection{Effect of Channel Geometry, Fluid Properties and Flowrates}

Han and Chen [58] carried out 3D numerical simulations of merged droplet formation in squeezing regime in a double T-junction. Authors investigated the effects of flowrate of continuous phase, continuous phase viscosity and interfacial tension. The authors found that the droplet formation involved three steps: filling of the dispersed phase flow in the T-junction, blocking of the T-junction and eventually breakup of the droplet. During this period there was a periodic pressure cycle resulting in pressure drop. The pressure cycle period was equal to the droplet breakup period. The authors found that when $\mathrm{Ca}$ number increased the slug lengths decreased while when the viscosity increased the droplet breakup time decreased and so did the pressure cycle time. However reverse trend was observed when surface tension was increased.

Yang et al. [56] carried out 2D CFD simulations in OpenFoam Opensource CFD code in a system consisting of a main channel and system of capillaries for seperating dispersed phase. Test system of Water-Toluene was used for this purpose. The seperation was made in such a way that when dispersed and continuous phases travel together the dispersed phase is drawn into the side capillaries and complete seperation occurs by applying high pressure at the continuous phase outlet (or the main channel). Thus the dispersed phase passes through the capillary. The authors defined the pressure range in which the system can be operated by calculating lower limit of pressure drop by Hagen-Poiseulle equation and the upper limit by the Young-Laplace equation.

Sripadaraja et al. [59] carried out 2D numerical investigations for squeezing regime $(0.0028<\mathrm{Ca}<0.008)$ and squeezing to dripping regime. Three different geometries namely, cross junction, coflow and T-junction were considered for investigation. The authors found that the effect of surfactants on droplet generation is nominal. With increase in flow velocity, $\mathrm{Ca}$ increases. For $\mathrm{Ca}=0.002$, droplet generation increased by $16 \%$. Similar to Han and Chen, [58], the authors defined a 3 step approach for droplet formation which the authors named Filling, necking and lag stage. Lan et al. [55], carried out 3D numerical simulations for two different geometries Co-tube microchannel and Flow focusing shape microchannel. A modified Level-Set method was used to resolve the interface movement due to the mass loss problem in original Level-Set method. The authors observed decrease in droplet sizes with increase in flow. Further, strong internal circulations were observed during the initial stages of droplet formation resulting in increase in transport property rates. However, the strength of the circulations decrease after droplet formation.

\subsubsection{Effect of Flow Regime}

Azarmaneesh and Farhadi, [22] studied droplet formation for $1<\operatorname{Re}<25$ for sqeezing regimes and stable and unstable jetting regimes. New vortices were created after droplet detachment when $\operatorname{Re}<1$. Droplet formation steps during squeezing regime were shown for $\mathrm{Re}=0.8$ and $\mathrm{Ca}=0.003$. At dripping regime the droplet formation was seen to be affected only by balance of shear stress and surface tension while inertia forces also influence the motion, changing droplet size and some new vortices in droplet. Kostinont et al. [54] carried out numerical investigations using the properties of glass. The channel structure was modifed by having guidelines at the centerline of the channels so that the interface is always at the center. The authors tried to get transition of parallel to slug transition by increase in flow velocities thus affecting Re numbers. DeMenech et al. [57] numerically 
investigated the mechanism of droplet breakup in squeezing, dripping and jetting regimes using the PhaseField method. The breakup process was found to be driven chiefly by buildup of pressure upstream of an emerging droplet. The capillary number was found to have a negligible effect on droplet size and dynamics of breakup. The dripping regime was influenced by the contrained geometry and modified the scaling law derived for size of droplets from interfacial and viscous stress balance. The jetting regime was found to set at high flow rates and higher values of Ca number.

The research works for CFD studies have considered flows in the slug flow regime. A numerical model was developed to study the slug flow patterns under different flow conditions and fluid properties Kashid et al. [14]. The authors validated their model with the experimental results. The authors found that CFD can be a very efficient tool for design of micro-extractors. Further, internal circulations inside the slugs (dispersed phase) as well as outside the slugs (continuous phase in between two slugs) were studied.

VOF based CFD methodology to simulate slug flow in micro-channels was used by some researchers Kashid et al. [44]. The authors considered two cases (i) when there is no film between the wall and the slugs and (ii) when the slug is seperated from the wall by a liquid film situations of slug flow were considered and validated. The authors found that VOF method described slug flow generation and its characteristics very well. The slug flow generation was found to depend on slug flow velocity and interfacial velocity. The authors also concluded that slug length can be preserved upto a channel diameter of $1 \mathrm{~mm}$.

\subsubsection{Effect of Channel Wettability}

Yamasaki et al. [53] studied stable parallel flow for Water- Octane system using the VOF model coupled with Continuum-Surface Force (CSF) model. The Capillary number and Weber numbers chosen for these studies were far less than 1 . The authors tried to simulate parallel flow which would aid the seperation of the two layers easily and reduce extra downstream equipment for seperation. 3D CFD studies of drop/slug formation in micro-channels were undertaken Raj et al. [42]. The drop-shape slug shape, slug lengths, slug formation was predicted with Volume of Fluid (VOF) interface tracking method along with Navier-Stokes governing equations for continuity and momentum and compared with measurements of Garstecki et al. [33]. The authors developed a CFD model to see the effect of wall adhesion on flow regimes and slug lengths. The authors claimed the model to be robust and that the model can be used to simulate mixing, transport processes and chemical reactions. However, the authors suggested that extensive and reliable measurements need to be carried out for simulating and predicting film thicknesses correctly. This is due to the effects of grid refinement near the walls, surface wettability and roughness of film thickness critically. Further, effect of surface tension at low velocity ranges have been found be independent on droplet diameter Sugiura et al. [32].

CFD studies were performed by $\mathrm{Fu},[36]$ to understand the velocity and pressure distribution in the configurations of the micro-channels considered. The numerical velocity profiles for different horizontal locations were compared with analytical solution. For $\mathrm{x} / \mathrm{L}=0.6$ and 0.4 for converging and diverging micro-channels results were in good agreement. Similarly, pressure distribution profiles were also compared with analytical solution. The converging pressure fell slowly near the entrance while decreased rapidly near the outlet. For diverging section, pressure fell rapidly near the entrance and slowly near the exit.

\section{Influence of Flow Patterns on Transport Property}

In this section, an effort has been made to summarize the findings of various authors specifically, the geometric parameters (like size of microchannel), operating parameters (flow velocity) on VMTC. While for most of the authors it was slug flow the major findings lie in the systems chosen for studies and parameteric studies by various authors. 


\subsection{Experimental Studies}

Major amount of experimental work by researchers [9,10,16,63-72] have been carried out in slug flow regime as seen from Table 5. The information on the geometry, operating parameters, experimental techniques, flow regimes of major LL systems, the findings, limitations and assumptions of the research works have been presented in Table 5.

\subsubsection{Effect of Geometric, Operating Parameters, Wallfilms and Fluid Properties on VMTC}

Kashid et al. [1] carried out studies in mass transfer systems for three different systems 1. Water-iodine-kerosene; 2. Kerosene-acetic-acid-water and 3. Water-succinic-acid-nbutanol at constant flow velocities. The authors found that the VMTC's varied from $(0.32$ to $0.98 \mathrm{~s}^{-1}$ ) for channel diameters of $500 \mu \mathrm{m}$ while it dropped to $\left(0.13-0.32 \mathrm{~s}^{-1}\right)$ for channel diameters of $1000 \mu \mathrm{m}$ for water-iodine-kerosene system. The authors found that internal circulations increase with flow velocity. Hence, VMTC increases due to higher internal circulations. The authors, also, found that flow ratio $(q)$ has a positive effect on VMTC. For water-succinic-acid-n-butanol system the extraction efficiencies decreased by around 10\% with increase in slug flow velocity for constant values of internal diameter of the capillary. Zhao et al. [16] have conducted experimental investigations with water/n-butanol/succinic acid with micro-channels having internal diameter of 300-600 $\mu \mathrm{m}$ and length $45 \mathrm{~mm}$. The authors observed an increase of VMTC values to about 4 times when the channels size was decreased from $600 \mu \mathrm{m}$ to $300 \mu \mathrm{m}$. Further, this was observed for Re numbers in the range of 500-600. Other researchers, [6,9] have operated their respective systems for low Reynolds numbers $(\operatorname{Re}<20)$ for toluene-trichloroacetic acid-water system for channel diameter of $400 \mu \mathrm{m}$ and found that the VMTC's less than 1. Other researchers, Di Miceli Raimondi et al. [70] have carried out measurements of VMTC's in diameters of around $300 \mu \mathrm{m}$. The VMTC's obtained by the authors were around $8.44 \mathrm{~s}^{-1}$ for $210 \mu \mathrm{m}$ while it decreased to around $2.65 \mathrm{~s}^{-1}$ for $300 \mu \mathrm{m}$ micro-channels. The Re range in such systems were less than 50 .

Dessimoz et al. [9] have used T-shaped and Y-shaped micro-channels. The authors used T-shaped micro-channel for generating slug flow while Y-shaped micro-channels were used for generating parallel flow. The authors have used hexane-water system for generation of slug flow while they added sodium hydroxide in the aqueous phase. Hexanetrichloroacetic acid-water-sodium hydroxide system was used due to higher interfacial forces responsible for the generation of slugs. Also addition of sodium hydroxide decreased the viscous forces and interfacial forces further dominated the system due to which slug flow could be formed. Xu et al. [69] carried out investigations on alkaline hydrolysis reactions for T-junction for slug flow (similar to Dessimoz et al. [9] and found increase in VMTC's with increase in NAOH concentrations

Ghaini et al. [66] studied the effect of wall film on transport property. The authors used the fast instantaneous reaction. Matsuoka et al. [73] studied the influence of wall films during slug flow in micro-channels. The authors found the variation of VMTC with Reynolds number for a fixed velocity and different hydraulic diameters ( $0.6 \mathrm{~mm}$ to $2 \mathrm{~mm}$ ) Maximum VMTC obtained was around $0.7 \mathrm{~s}^{-1}$ for a constant channel length. The VMTC was found to be a strong function of slug flow velocity and decreased due to resistance due to wall film.

Di Miceli Raimondi et al. [70] carried out measurements for dispersed phase VMTCs using the water toluene system. The maximum inlet velocities measured were up to $300 \mathrm{~mm} / \mathrm{s}$ and high values of transport properties are obtained.

Arsenjuk et al. [71] carried out experimental investigations for a kerosene-glycerolwater system to see the effect of film thickness on transport property. The authors found that film thicknesses were higher for systems having a transfer component than systems not having transfer component. This influences the transport property. This study deserves special significance since the presence of transfer component affects two phase investigations and affects the flow properties. 
Sattari-Najafabadi et al. [74] have also performed investigations to study the effect of shape of microchannels on the VMTC. Sattari-Najafabadi et al. [74] have found the impact of geometric configuration i.e., change in channel width $(W)$ and type of junction. The authors used the T-junction, cross junction and cross T-junction to understand the effect on VMTC. Further, the channel width $(\mathrm{W})$ to depth $(\mathrm{H})$ ratio $(\mathrm{W} / \mathrm{H})$ was varied $(1 \leq W / H \leq 2)$. The flow ratio $(q)$ was varied from 0.5 to 2 . The authors concluded that best VMTC's can be obtained for a cross-junction with flow ratio of 0.5 .

Sattari-Najafabadi and Esfahany, [75] carried out experimental investigations to find the effect of surfactant on VMTC during two phase flow of a LLE system. The authors observed that VMTC obtained in presence of surfactant was 1.44 times better than VMTC without surfactant.

\subsubsection{Comparison of VMTC's of Microchannels and Conventional Equipments}

Singh et al. [76] carried out experimental investigations to compare the performance of different microchannels with conventional extraction equipments. The authors considered three different micro-channels namely T-junction micro-channels, serpentine microchannels and split and recombine micro-channels for experimentation. The authors observed that the process intensification possible by using micro-channels has the potential to reduce solvent inventory 10 times and correspondingly reduce health hazard and plant foot print. Process intensification can occur only for shorter contact times since for longer contact times results were similar for conventional extractors and microchannels.

Sahu et al. [77] carried out experimental investigations and compared the performance of continuous micro-channels v/s batch systems. Experiments were performed both in batch and micro-channels. They considered square $\mathrm{Y}$ and serpentine micro-channels for experiments. The authors observed superior performance of micro-channels than batch systems. This is attributed to strong internal circulations induced by shear between slugs and wall.

\subsubsection{Evaluation of VMTC's for Systems Involving IL's, DES as Solvents}

Bai et al. [10] considered water-Rhodamine6G-ionic liquid system to find the VMTC in microchannels of width $1 \mathrm{~mm}$ and depth $0.3 \mathrm{~mm}$. Two types of geometric configurations mainly crossing junction and T-junction were used for investigation. Empirical correlations to predict VMTC were obtained from experimental data. The VMTC was found to be a strong function of flow ratio and Reynolds number. The measured and predicted VMTC's matched well with less deviations.

Tsaoulidis et al. [31] carried out studies of Dioxo-Uranium VI extraction from aqueous nitric acid using ILs. T-junction micro-channels were used. Slug flow was found to be the flow pattern during their study. The transport property/efficiency of the microchannel was influenced by the presence of low initial concentration of nitric acid.

Li and Angeli, [72] carried out experimental investigations for extraction of lanthanides. The authors used IL's to extract lanthanides from nitric acid. The authors observed that the parameters that affected the VMTC were flow ratio, length of microchannel and initial concentration of nitric acid.

He et al. [78] have carried out investigation on extraction of rare earths $\mathrm{Pr} / \mathrm{Nd}$ from chloride solutions with Deep Eutectic Solvents (DES) using Y-junction serpentine microchannels. Jiang et al. [79] have carried out separation of lanthanum (La) and Cerium (Ce) from chlorides in serpentine micro-extractors and rectangular cross-sections. Sen et al. [80] used serpentile micro-channels for extraction of Uranium from Tributyl phosphate in dodecane (aqueous phase). Annular flow was obtained for phase ratio of 2 while after 2 the flows were in droplet regime. All the investigations involving rare earths had Re values in the range $\operatorname{Re}<25$ and VMTC values ranged from 0.05 to $0.17 \mathrm{~s}^{-1}$. 
Table 5. Literature of experimental works on flow patterns and its influence on transport properties.

\begin{tabular}{|c|c|c|c|c|c|c|c|c|c|c|c|c|}
\hline \multirow[t]{2}{*}{ Authors } & \multicolumn{4}{|c|}{ Channel Details } & \multicolumn{3}{|c|}{ Type of Study } & \multirow[b]{2}{*}{$\begin{array}{c}\text { Flow } \\
\text { Regime }\end{array}$} & \multirow[b]{2}{*}{$\begin{array}{l}\text { Parameters } \\
\text { Varied }\end{array}$} & \multirow[b]{2}{*}{ Assumptions } & \multirow[b]{2}{*}{$\begin{array}{c}\text { Limitations/ } \\
\text { Opportunities }\end{array}$} & \multirow[b]{2}{*}{ Findings } \\
\hline & $\begin{array}{c}\text { Geometry } \\
\text { Type }\end{array}$ & $\begin{array}{l}\text { Channel } \\
\text { Diameter }\end{array}$ & $\begin{array}{c}\text { Channel } \\
\text { Length }(\mathrm{mm})\end{array}$ & Channel Material & $\begin{array}{c}\text { Flow } \\
\text { Rate/Velocity }\end{array}$ & $\begin{array}{l}\text { Experimental/ } \\
\text { CFD }\end{array}$ & System & & & & & \\
\hline $\begin{array}{l}\text { Kashid } \\
\text { et al. [1] }\end{array}$ & $\begin{array}{l}\text { Micro- } \\
\text { capillary, } \\
\text { Y-Type }\end{array}$ & $0.5,0.75,1$ & 100-1000 & $\begin{array}{l}\text { Polytetraflouroe- } \\
\text { thylene (PTFE) for } \\
\text { channel and flow } \\
\text { splitters, steel for } \\
\text { outlet channel in } \\
\text { flow splitter }\end{array}$ & $5-60 \mathrm{~mL} / \mathrm{h}$ & Experimental & $\begin{array}{c}\text { Non-reacting } \\
\text { system } \\
\text { Water-iodine- } \\
\text { kerosene; } \\
\text { Kerosene-acetic } \\
\text { acid-water; } \\
\text { Water-succinic } \\
\text { acid-n-butanol }\end{array}$ & Slug flow & $\begin{array}{l}\text { Capillary } \\
\text { diameter, slug } \\
\text { velocity, flow } \\
\text { ratio of aqueous } \\
\text { and organic } \\
\text { phases }\end{array}$ & 1,2 & 1 & $\begin{array}{c}1,2,3,4 \\
5\end{array}$ \\
\hline $\begin{array}{c}\text { Zhao et al. } \\
\text { [16] }\end{array}$ & $\begin{array}{l}\text { Rectangular } \\
\text { micro-channel, } \\
\text { T-type }\end{array}$ & $\begin{array}{c}0.4 \times 0.6 ; 0.6 \times \\
0.6\end{array}$ & & Stainless steel & $\begin{array}{l}0.01-2.5 \mathrm{~m} / \mathrm{s} ; \\
0.005-2 \mathrm{~m} / \mathrm{s}\end{array}$ & Experimental & $\begin{array}{l}\text { Water-succinic } \\
\text { acid-n-butanol }\end{array}$ & NA & $\begin{array}{l}\text { Type of flow: } \\
\text { opposed and } \\
\text { cross flow; height } \\
\text { of channel; } \\
\text { velocity of fluids }\end{array}$ & 3 & 1 & $6,7,8$ \\
\hline $\begin{array}{l}\text { Dessimoz } \\
\text { et al. [9] }\end{array}$ & $\begin{array}{l}\text { Rectangular } \\
\text { micro-channel, } \\
\text { Y-Type and } \\
\text { T-type }\end{array}$ & $\begin{array}{c}0.25 \times 0.292 \text { for } \\
\text { Y type; } 0.4 \times \\
0.4 \text { for T-type }\end{array}$ & $\begin{array}{c}40 \text { for } Y \text { type } \\
\text { and } 56 \text { for } \mathrm{T} \\
\text { type }\end{array}$ & Glass & & Experimental & $\begin{array}{c}\text { Reacting system, } \\
\text { Hexane- } \\
\text { trichloroacetic } \\
\text { acid-water + } \\
\text { NaOH; Toluene- } \\
\text { trichloroacetic } \\
\text { acid-water + } \\
\text { NaOH }\end{array}$ & $\begin{array}{l}\text { Slug flow and } \\
\text { parallel flow }\end{array}$ & $\begin{array}{l}\text { Linear velocity of } \\
\text { fluids, initial } \\
\text { concentration of } \\
\text { water }\end{array}$ & 4,5 & 1,2 & 9,10 \\
\hline $\begin{array}{l}\text { Assmann } \\
\text { \& von } \\
\text { Rohr, [67] }\end{array}$ & $\begin{array}{l}\text { Micro- } \\
\text { capillary }\end{array}$ & 0.22 & 1350 & Polydimethylsiloxane & $\begin{array}{l}\text { Overall } \\
\text { flowrate: } 0.26 \\
\mathrm{~mL} / \mathrm{min}\end{array}$ & Experimental & $\begin{array}{c}\text { Non-reactive } \\
\text { system: } \\
\text { Water-Vanillin- } \\
\text { toluene with } \\
\text { Nitrogen as } \\
\text { carrier gas }\end{array}$ & $\begin{array}{l}\text { Segmented/ } \\
\text { Slug flow } \\
\text { without carrier } \\
\text { gas }\end{array}$ & $\begin{array}{c}\text { VMTC, } \\
\text { extraction } \\
\text { efficiency, } \\
\text { velocity profiles }\end{array}$ & 3,5 & 1,2 & 13,14 \\
\hline $\begin{array}{l}\text { Tang et al. } \\
\text { [81] }\end{array}$ & $\begin{array}{l}\text { Vertical flow } \\
\text { microchannel }\end{array}$ & $0.8 ; 1.2$ & 236 & Glass & $\begin{array}{c}0.237-0.373 \\
\mathrm{~mL} / \mathrm{min} \text { based } \\
\text { on total } \\
\text { velocity }\end{array}$ & Experimental & $\begin{array}{l}\text { Water-succinic } \\
\text { acid-n-butanol }\end{array}$ & Droplet flow & $\begin{array}{l}\text { Flow rate, total } \\
\text { flow velocity }\end{array}$ & $3,4,5$ & 1,2 & 11,12 \\
\hline $\begin{array}{l}\text { Tsaoulidis } \\
\text { et al. [82] }\end{array}$ & $\begin{array}{c}\text { T-junction } \\
\text { microchannel }\end{array}$ & 0.5 & $100-300$ & $\begin{array}{l}\text { Polymethyl- } \\
\text { metacrylate } \\
\text { (PMMA) }\end{array}$ & & Experimental & $\begin{array}{c}\text { Non-reactive } \\
\text { system: } \\
\text { Nitric } \\
\text { acid-U(IV)-Ionic } \\
\text { liquid }\end{array}$ & Slug flow & $\begin{array}{l}\mathrm{pH} \text {, residence } \\
\text { time, channel } \\
\text { width, flow } \\
\text { velocity, phase } \\
\text { flow ratio }\end{array}$ & 3,5 & 1 & 16 \\
\hline
\end{tabular}


Table 5. Cont.

\begin{tabular}{|c|c|c|c|c|c|c|c|c|c|c|c|c|}
\hline \multirow[t]{2}{*}{ Authors } & \multicolumn{4}{|c|}{ Channel Details } & \multicolumn{3}{|c|}{ Type of Study } & \multirow[b]{2}{*}{$\begin{array}{c}\text { Flow } \\
\text { Regime }\end{array}$} & \multirow[b]{2}{*}{$\begin{array}{l}\text { Parameters } \\
\text { Varied }\end{array}$} & \multirow[b]{2}{*}{ Assumptions } & \multirow[b]{2}{*}{$\begin{array}{c}\text { Limitations/ } \\
\text { Opportunities }\end{array}$} & \multirow[b]{2}{*}{ Finding } \\
\hline & $\begin{array}{c}\text { Geometry } \\
\text { Type }\end{array}$ & $\begin{array}{l}\text { Channel } \\
\text { Diameter }\end{array}$ & $\begin{array}{c}\text { Channel } \\
\text { Length }(\mathrm{mm})\end{array}$ & Channel Material & $\begin{array}{c}\text { Flow } \\
\text { Rate/Velocity }\end{array}$ & $\begin{array}{c}\text { Experimental/ } \\
\text { CFD }\end{array}$ & System & & & & & \\
\hline $\begin{array}{c}\text { Xu et al. } \\
\text { [69] }\end{array}$ & $\begin{array}{l}\text { Micro- } \\
\text { capillary, } \\
\text { T-type }\end{array}$ & $0.6,0.8,1$ & $\begin{array}{c}500,1000,1500 \\
2000,2500\end{array}$ & Teflon & $5-100 \mathrm{~mL} / \mathrm{h}$ & Experimental & $\begin{array}{l}\text { Reacting system: } \\
\text { Sodium } \\
\text { hydroxide- } \\
\text { nbutyl acetate } \\
\text { (Alkaline } \\
\text { hydrolysis } \\
\text { reaction: Mass } \\
\text { transfer with fast } \\
\text { chemical } \\
\text { reaction) }\end{array}$ & Slug flow & $\begin{array}{l}\text { slug velocity, } \\
\text { channel length }\end{array}$ & 3,5 & 4,5 & $\begin{array}{c}8,17,18 \\
19\end{array}$ \\
\hline $\begin{array}{l}\text { Di Miceli } \\
\text { Raimondi } \\
\text { et al. [70] }\end{array}$ & $\begin{array}{c}\text { Square } \\
\text { microchannel }\end{array}$ & $\begin{aligned} 0.21 & \times 0.21 ; 0.3 \\
& \times 0.3\end{aligned}$ & $350-1640$ & Silicon and glass & $2.5-30 \mathrm{~mL} / \mathrm{h}$ & Experimental & $\begin{array}{l}\text { Non-reacting } \\
\text { system: } \\
\text { Water-acetone- } \\
\text { toluene }\end{array}$ & Slug flow & $\begin{array}{l}\text { droplet velocity, } \\
\text { droplet volume }\end{array}$ & 3,5 & 6 & 20,21 \\
\hline $\begin{array}{l}\text { Singh et al. } \\
\text { [76] }\end{array}$ & $\begin{array}{l}\text { T-junction } \\
\text { microchannel } \\
\text { Serpentine } \\
\text { microchannel } \\
\text { Split and } \\
\text { recombine } \\
\text { microchannel }\end{array}$ & $\begin{array}{c}\text { Equivalent } \\
\text { diameter: } \\
0.278,0.319\end{array}$ & & $\begin{array}{l}\text { Poly Ether Ether } \\
\text { Ketone (PEEK); } \\
\text { FRX200, from } \\
\text { Syrris Pvt Ltd. }\end{array}$ & $\begin{array}{l}0.01-10 \\
\mathrm{~mL} / \mathrm{min}\end{array}$ & Experimental & $\begin{array}{l}\text { Water-succinic } \\
\text { acid-n-butanol }\end{array}$ & $\begin{array}{l}\text { Parallel and } \\
\text { slug flow }\end{array}$ & $\begin{array}{l}\text { Phase ratio, } \\
\text { residence time, } \\
\text { flow velocity }\end{array}$ & 3,5 & 1,2 & 26 \\
\hline $\begin{array}{c}\text { Bai et al. } \\
\text { [10] }\end{array}$ & $\begin{array}{l}\text { T-junction and } \\
\text { crossing } \\
\text { junction } \\
\text { microchannels }\end{array}$ & $0.3 \times 0.5$ & 650 & $\begin{array}{l}\text { Polymethyl- } \\
\text { metacrylate }\end{array}$ & $\begin{array}{c}0.005-0.02 \\
\mathrm{~mL} / \mathrm{min}\end{array}$ & Experimental & $\begin{array}{c}\text { Non-reactive } \\
\text { system: } \\
\text { Water-Rhodamin } \\
\text { 6G-Ionic Liquid }\end{array}$ & Slug flow & Flow rate, time & 3,5 & 8 & 8,28 \\
\hline $\begin{array}{l}\text { Li \& } \\
\text { Angeli, } \\
\text { [72] }\end{array}$ & $\begin{array}{c}\text { T-junction } \\
\text { micro-capillary }\end{array}$ & $0.2-0.5$ & $50-250$ & Quartz & $\begin{array}{c}0.653-21.205 \\
\mathrm{~mL} / \mathrm{min}\end{array}$ & Experimental & $\begin{array}{c}\text { Non-reactive } \\
\text { System: } \\
\text { Nitric } \\
\text { acid-Eu(III)-Ionic } \\
\text { liquid }\end{array}$ & Slug flow & $\begin{array}{l}\text { Time, mixture } \\
\text { velocity }\end{array}$ & 3,5 & 1,2 & 8 \\
\hline $\begin{array}{l}\text { Matsuoka } \\
\text { et al. [73] }\end{array}$ & $\begin{array}{l}\text { Circular } \\
\text { channel }\end{array}$ & $\begin{array}{c}0.6-2 \text { of } \\
\text { channel and } \\
\text { inlet diameters } \\
\text { of } 2 \text { and } 2.4\end{array}$ & $100-1200$ & Stainless steel & $0.5-8 \mathrm{~mL} / \mathrm{min}$ & Experimental & $\begin{array}{l}\text { Non-reactive } \\
\text { system: } \\
\text { Water-phenol- } \\
\text { dodecane }\end{array}$ & Slug flow & $\begin{array}{c}\text { Reynolds } \\
\text { number, } \\
\text { Residence time }\end{array}$ & 3,5 & 9 & 8,30 \\
\hline $\begin{array}{l}\text { Sahu et al. } \\
\text { [77] }\end{array}$ & $\begin{array}{l}\text { Y-junction } \\
\text { Serpentine } \\
\text { square } \\
\text { microchannels }\end{array}$ & $0.15 \times 0.15$ & $\begin{array}{l}56, \\
266\end{array}$ & PTFE & $0.04-0.1$ & Experimental & $\begin{array}{c}\text { Non-reactive } \\
\text { system: } \\
\text { Water-propionic } \\
\text { acid-toluene }\end{array}$ & $\begin{array}{l}\text { Parallel and } \\
\text { slug flow }\end{array}$ & $\begin{array}{l}\text { Phase ratio, } \\
\text { residence time, } \\
\text { flow velocity }\end{array}$ & 3,5 & 2 & 31,32 \\
\hline
\end{tabular}


Table 5. Cont.

\begin{tabular}{|c|c|c|c|c|c|c|c|c|c|c|c|c|}
\hline \multirow[t]{2}{*}{ Authors } & \multicolumn{4}{|c|}{ Channel Details } & \multicolumn{3}{|c|}{ Type of Study } & \multirow[b]{2}{*}{$\begin{array}{c}\text { Flow } \\
\text { Regime }\end{array}$} & \multirow[b]{2}{*}{$\begin{array}{l}\text { Parameters } \\
\text { Varied }\end{array}$} & \multirow[b]{2}{*}{ Assumptions } & \multirow[b]{2}{*}{$\begin{array}{c}\text { Limitations/ } \\
\text { Opportunities }\end{array}$} & \multirow[b]{2}{*}{ Findings } \\
\hline & $\begin{array}{c}\text { Geometry } \\
\text { Type }\end{array}$ & $\begin{array}{l}\text { Channel } \\
\text { Diameter }\end{array}$ & $\begin{array}{c}\text { Channel } \\
\text { Length }(\mathrm{mm})\end{array}$ & Channel Material & $\begin{array}{c}\text { Flow } \\
\text { Rate/Velocity }\end{array}$ & $\begin{array}{c}\text { Experimental/ } \\
\text { CFD }\end{array}$ & System & & & & & \\
\hline $\begin{array}{l}\text { Ani et al. } \\
\text { [83] }\end{array}$ & $\begin{array}{l}\text { Circular } \\
\text { channel }\end{array}$ & $\begin{array}{l}1.22 \mathrm{~mm} \\
\text { diameter }\end{array}$ & $100-300$ & Glass & & Experimental & $\begin{array}{l}\text { Non-reactive } \\
\text { system: } \\
\text { Liquid fuel- } \\
\text { dibenzothiophene- } \\
\text { DES } \\
\text { solvent }\end{array}$ & $\begin{array}{l}\text { Slug flow, } \\
\text { Intermittent } \\
\text { flow, Annular } \\
\text { flow }\end{array}$ & $\begin{array}{l}\text { Mixture velocity, } \\
\text { DES volume } \\
\text { fraction, channel } \\
\text { length }\end{array}$ & 3,5 & 8 & 8,28 \\
\hline $\begin{array}{c}\text { Cao et al. } \\
\text { [15] }\end{array}$ & $\begin{array}{c}\text { Rectangular } \\
\text { microchannels }\end{array}$ & $\begin{array}{c}\text { Hydraulic dia.: } \\
0.2,0.4,0.6\end{array}$ & 105 & Glass & $0.2-150 \mathrm{~mm} / \mathrm{s}$ & Experimental & $\begin{array}{l}\text { Water-butanol; } \\
\text { Water-toluene; } \\
\text { Water-hexane }\end{array}$ & $\begin{array}{l}\text { All flow } \\
\text { patterns } \\
\text { described }\end{array}$ & $\begin{array}{l}\text { flow velocity, } \\
\text { channel width }\end{array}$ & 3,5 & $1,10,11$ & 8,33 \\
\hline $\begin{array}{c}\text { Sattari- } \\
\text { Najafabadi } \\
\text { and } \\
\text { Esfahany, } \\
\text { [75] }\end{array}$ & $\begin{array}{c}\text { Circular } \\
\text { microchannel }\end{array}$ & 0.6 & & PTFE & $\begin{array}{c}0.083-0.217 \\
\mathrm{~mL} / \mathrm{min}\end{array}$ & Experimental & $\begin{array}{l}\text { Reactive system: } \\
\text { Water (with } \\
\text { NaOH)- } \\
\text { trichloroacetic } \\
\text { acid-nhexane in } \\
\text { presence of } \\
\text { sodium dodecyl } \\
\text { sulfate }\end{array}$ & Slug flow & Flow rate & 3,5 & 1 & $\begin{array}{l}35,36 \\
37\end{array}$ \\
\hline $\begin{array}{l}\text { Sattari- } \\
\text { Najafabadi } \\
\text { et al. [74] }\end{array}$ & $\begin{array}{c}\text { Square and } \\
\text { rectangular } \\
\text { microchannel } \\
\text { with } 3 \text { different } \\
\text { junctions } \\
\text { (cross and } \\
\text { Tshape) }\end{array}$ & $\begin{array}{l}0.4 \times 0.4 \\
0.3 \times 0.6\end{array}$ & 120 & Borosilicate glass & $\begin{array}{l}0.1-0.55 \\
\mathrm{~mL} / \mathrm{min}\end{array}$ & Experimental & $\begin{array}{l}\text { Fast Reactive } \\
\text { system: } \\
\text { Water (with } \\
\text { NaOH)-acetic } \\
\text { acid-n-hexane }\end{array}$ & Slug flow & Flow rate & 3,5 & 1 & $8,38,39$ \\
\hline $\begin{array}{l}\text { He et al., } \\
\text { [78] }\end{array}$ & $\begin{array}{l}\text { Rectangular } \\
\text { Yjunction } \\
\text { serpentile } \\
\text { channels }\end{array}$ & $0.3-1$ & 125 & Stainless steel & $0.02-0.15 \mathrm{~m} / \mathrm{s}$ & Experimental & $\begin{array}{l}\text { Non-reactive } \\
\text { system: } \\
\text { Pr/Nd from } \\
\text { chloride solution } \\
\text { 2-ethyl-hexyl } \\
\text { phosphoric acid } \\
\text { ester }\end{array}$ & Slug flow & $\begin{array}{l}\mathrm{pH} \text {, residence } \\
\text { time, channel } \\
\text { width, flow } \\
\text { velocity }\end{array}$ & 3,5 & 1,2 & 40,41 \\
\hline $\begin{array}{l}\text { Jiang et al. } \\
\text { [79] }\end{array}$ & $\begin{array}{l}\text { Rectangular } \\
\text { microchannels } \\
\text { for serpentine } \\
\text { micro-reactors }\end{array}$ & 0.5 & 125 & $\begin{array}{l}\text { Polymethyl- } \\
\text { metacrylate }\end{array}$ & $0.56-3 \mathrm{~mm}^{3} / \mathrm{s}$ & Experimental & $\begin{array}{l}\text { Non-reactive } \\
\text { system: } \\
\text { La/Ce from } \\
\text { chloride solution } \\
\text { 2-ethyl-hexyl } \\
\text { phosphoric acid } \\
\text { ester }\end{array}$ & Slug flow & $\begin{array}{l}\text { Residence time, } \\
\text { channel width, } \\
\text { flow velocity }\end{array}$ & 3,5 & 1,2 & 40,41 \\
\hline
\end{tabular}


Table 5. Cont.

\begin{tabular}{|c|c|c|c|c|c|c|c|c|c|c|c|c|}
\hline \multirow[t]{2}{*}{ Authors } & \multicolumn{4}{|c|}{ Channel Details } & \multicolumn{3}{|c|}{ Type of Study } & \multirow[b]{2}{*}{$\begin{array}{c}\text { Flow } \\
\text { Regime }\end{array}$} & \multirow[b]{2}{*}{$\begin{array}{l}\text { Parameters } \\
\text { Varied }\end{array}$} & \multirow[b]{2}{*}{ Assumptions } & \multirow[b]{2}{*}{$\begin{array}{c}\text { Limitations/ } \\
\text { Opportunities }\end{array}$} & \multirow[b]{2}{*}{ Findings } \\
\hline & $\begin{array}{c}\text { Geometry } \\
\text { Type }\end{array}$ & $\begin{array}{c}\text { Channel } \\
\text { Diameter }\end{array}$ & $\begin{array}{c}\text { Channel } \\
\text { Length }(\mathrm{mm})\end{array}$ & $\begin{array}{l}\text { Channel } \\
\text { Material }\end{array}$ & $\begin{array}{c}\text { Flow } \\
\text { Rate/Velocity }\end{array}$ & $\begin{array}{l}\text { Experimental/ } \\
\text { CFD }\end{array}$ & System & & & & & \\
\hline He et al. [84] & $\begin{array}{l}\text { T-junction } \\
\text { microreactor }\end{array}$ & $1.5-6.5$ & 1000 & Stainless steel & $0.1-1 \mathrm{~mL} / \mathrm{min}$ & Experimental & $\begin{array}{l}\text { Non-reactive } \\
\text { system: } \\
\text { Hydrochloric } \\
\text { acid-smarium- } \\
2- \\
\text { ethylhexyl } \\
\text { phosphonic } \\
\text { acid mono-2- } \\
\text { ethylhexyl } \\
\text { (EHEHPA or } \\
\text { P507) }\end{array}$ & NA & $\begin{array}{l}\text { Channel width, } \\
\text { pH, channel } \\
\text { length }\end{array}$ & 3,5 & 1,12 & $42,43,44$ \\
\hline Sen et al. [80] & $\begin{array}{c}\text { Serpentile } \\
\text { microchannel } \\
\text { with microbore }\end{array}$ & 0.75 & 7300 & & $\begin{array}{l}0.01-10 \\
\mathrm{~mL} / \mathrm{min}\end{array}$ & Experimental & $\begin{array}{l}\text { Non-reactive } \\
\text { system: } \\
\text { Tributyl } \\
\text { phosphate in } \\
\text { Dodecane- } \\
\text { Uranium }\end{array}$ & $\begin{array}{l}\text { Annular and } \\
\text { droplet flow }\end{array}$ & $\begin{array}{l}\text { Phase ratio, } \\
\text { residence time, } \\
\text { flow velocity }\end{array}$ & 3,5 & 1,2 & 45 \\
\hline Wu et al., [11] & $\begin{array}{c}\text { T-junction, } \\
\text { crossjunction } \\
\text { straight } \\
\text { microchannels }\end{array}$ & $0.2-0.6$ & 50 & Glass & $4-90 \mathrm{~mL} / \mathrm{h}$ & Experimental & $\begin{array}{c}\text { Non-reactivev } \\
\text { systems: } \\
\text { Water-Silicon } \\
\text { Oil; } \\
\text { Water-toluene; } \\
\text { water- } \\
\text { 1butanol; } \\
\text { n-hexane; } \\
\text { mineral oil }\end{array}$ & $\begin{array}{l}\text { Tubing, } \\
\text { dripping, } \\
\text { jetting flow }\end{array}$ & $\begin{array}{l}\text { flow velocity; } \\
\text { flow rate }\end{array}$ & 3,5 & 10 & 33 \\
\hline $\begin{array}{l}\text { Zhang et al. } \\
\text { [12] }\end{array}$ & Microcapillary & $0.8-1.8$ & 200 & PTFE & & Experimental & $\begin{array}{l}\text { Toluene-water; } \\
\text { Toluene- } \\
\text { sulfuric-acid; } \\
\text { Ethylacetate- } \\
\text { water }\end{array}$ & $\begin{array}{l}\text { Tubing, } \\
\text { dripping, } \\
\text { jetting flow }\end{array}$ & $\begin{array}{c}\text { Channel } \\
\text { Diameter } \\
\text { Temperature }\end{array}$ & 3,5 & 1,2 & 33,46 \\
\hline Yao et al. [85] & $\begin{array}{l}\text { Meandering } \\
\text { microchannel }\end{array}$ & $0.3 \times 0.6$ & 440 & Glass & $\begin{array}{c}0.1-0.9 \\
\mathrm{~mL} / \mathrm{min}\end{array}$ & Experimental & $\begin{array}{l}\text { water (with } \\
\text { NaOH)-acetic } \\
\text { acid-toluene; }\end{array}$ & Slug flow & $\begin{array}{l}\text { Flow rate, effect } \\
\text { of continuous } \\
\text { and dispersed } \\
\text { phase using } \\
\text { glycerol and } \\
\text { silicon oil content } \\
\text { variation }\end{array}$ & 3,5 & 12 & 8,47 \\
\hline
\end{tabular}

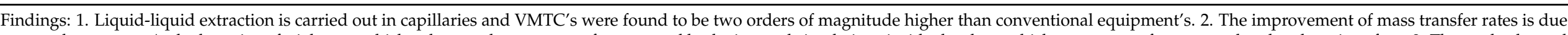

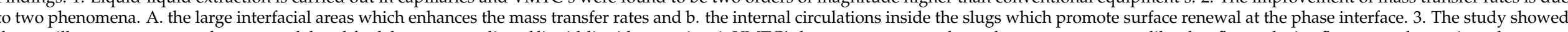

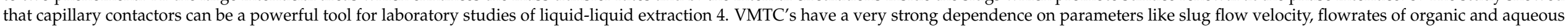

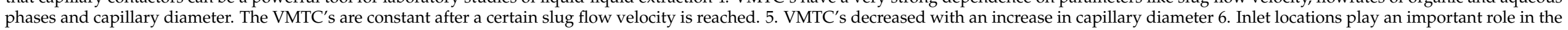

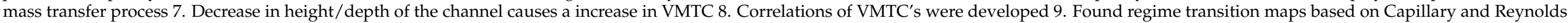

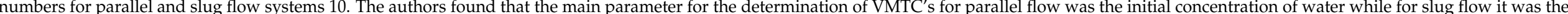

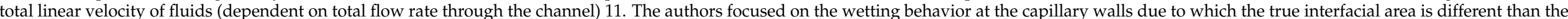




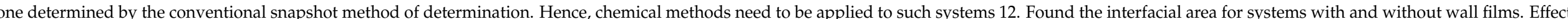

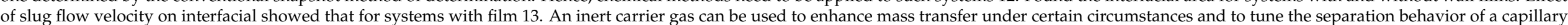

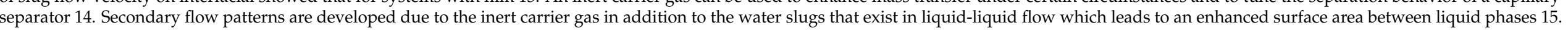

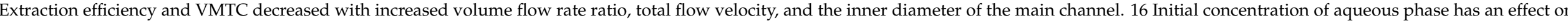

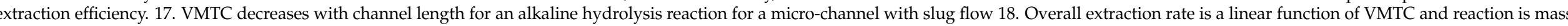

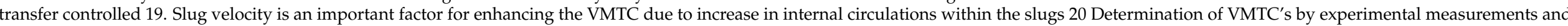

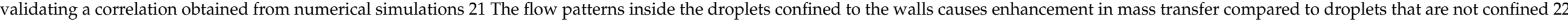

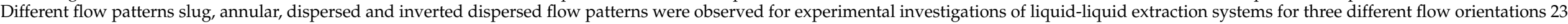

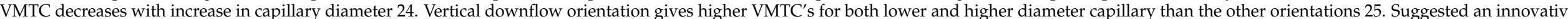

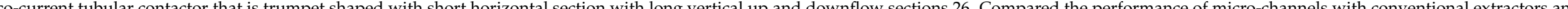

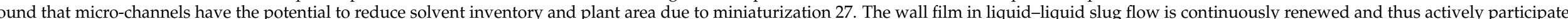

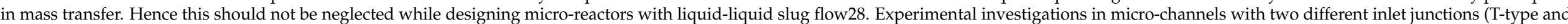

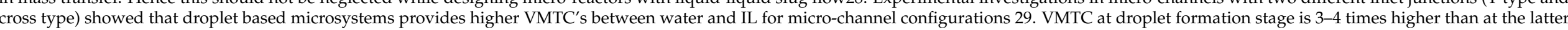

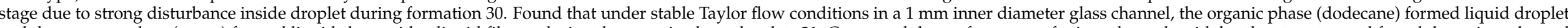

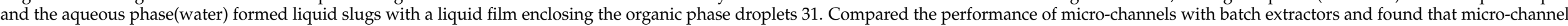

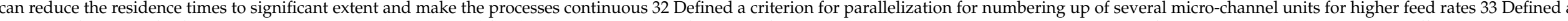

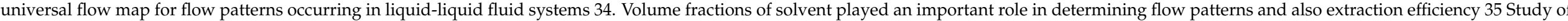

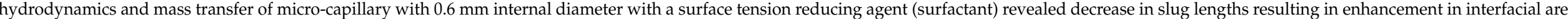

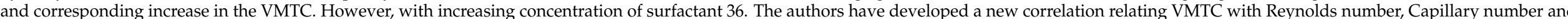
VMTCs due to enlargement of the dispersed phase slugs and reduction of wall film renewal 39. Studies with T-junctions and cross junctions for mixing was also carried out where

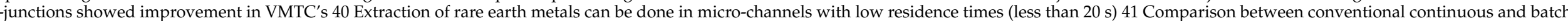

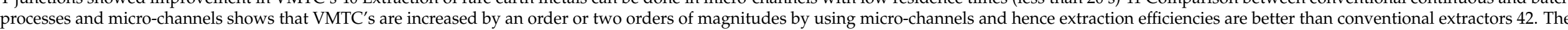

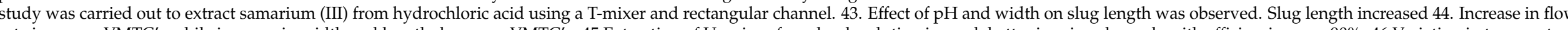

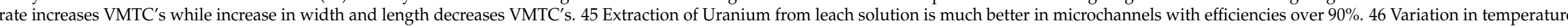

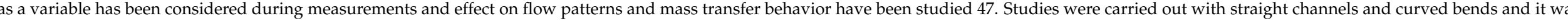

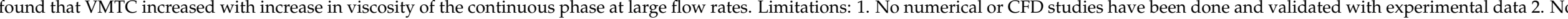

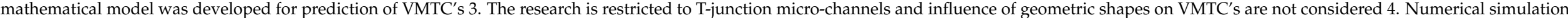

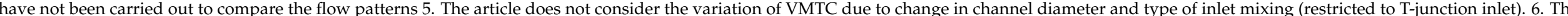

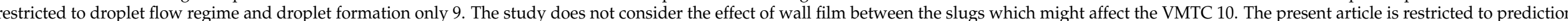

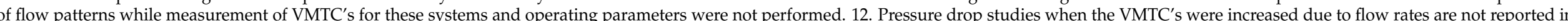

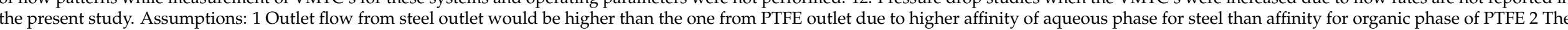

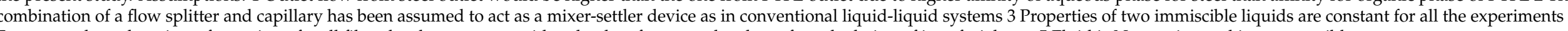
For cases where there is no formation of wall film, the slugs were considered to be of rectangular shape for calculation of interfacial area 5 Fluid is Newtonian and incompressible. 


\subsubsection{Comprehensive Regime Map for LL Systems Having Transferable Component}

In Section 2.2, the regime maps presented by various researchers for two phase systems have been discussed. The flow regime maps are based on combination of dimensionless numbers which is the interplay between the inertial, viscous and surface tension forces. However, in Section 3.1. Arsenjuk et al. [71] have found that the presence of a transferable component affects the dynamics of two phase LL systems. The product of Weber number and Ohnesorge number for both continuous and dispersed phase seems to be a good way to represent the flow regimes. An effort has been made to collate the data of the LL systems having a transfer component and see if they adhere to the regime map provided by [7].

Figure 13 shows the plot of flow regimes. Yagodnitsyna et al. [7] (Figure 7) have shown a very comprehensive universal flow regime map which however deviates from the findings of the various authors in slug flow regime. During our analysis, we find a disparity in flow patterns shown by several authors. The present analysis shows that many of the literature works fall in the area of parallel flow in the regime map of Yagodnitsyna et al. [7] while in experimental works of researchers, they are in slug flow Kashid et al. [6].

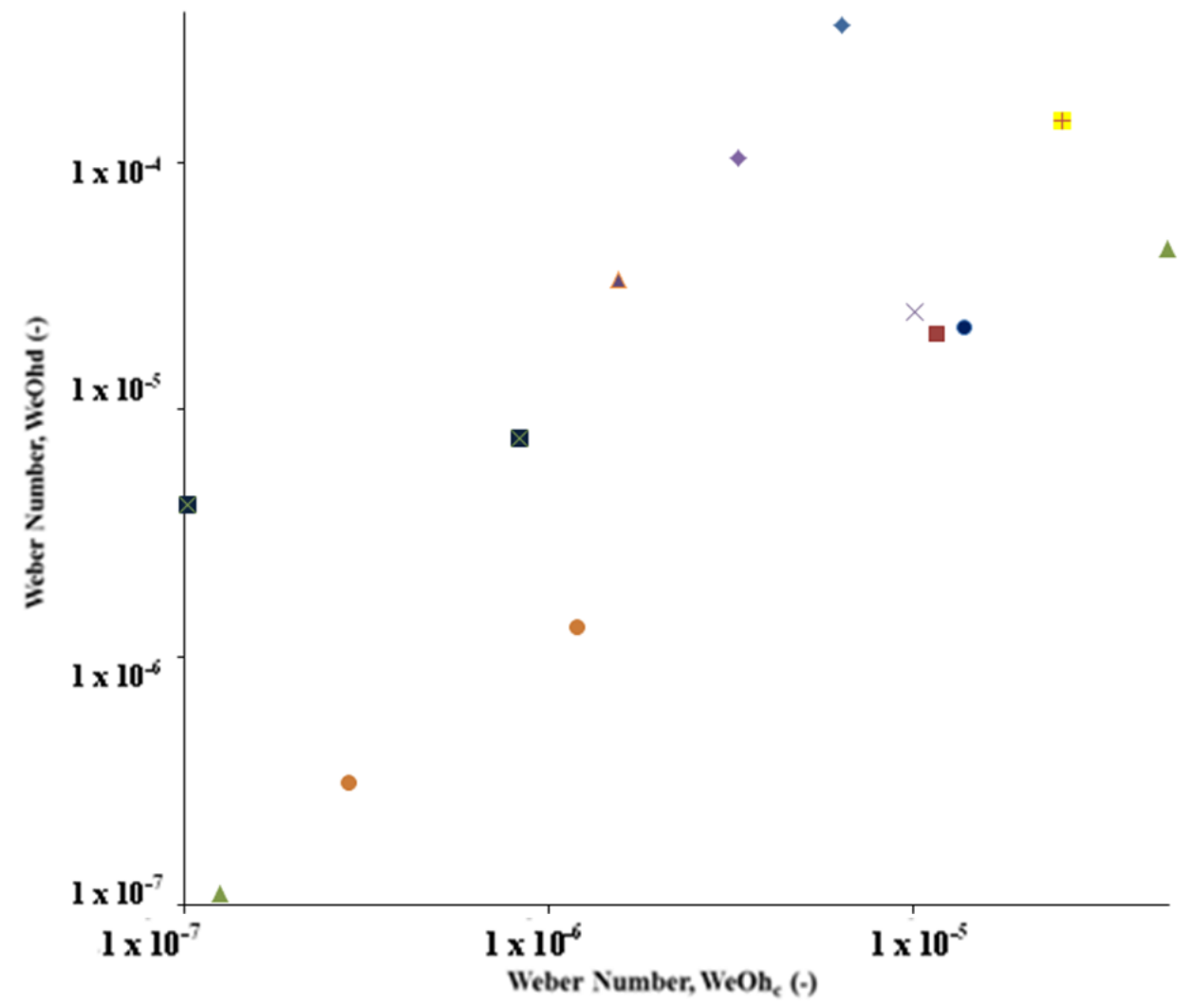

Figure 13. Flow map prepared by integrating various works of the literature. $\bullet$ Kashid et al. [1], $\mathrm{D}=0.5 \mathrm{~mm}$; Kashid et al. [1], D = $1 \mathrm{~mm} ; \boldsymbol{\Delta}$ Dessimoz et al. [9], D = $0.4 \mathrm{~mm}$; $\times$ Ghaini et al. [66], $\mathrm{D}=1 \mathrm{~mm}$; Assmann and von Rohr, [67], D = $0.22 \mathrm{~mm}$; Tang et al. [81], D = $1.2 \mathrm{~mm}$; $\bullet$ Xu et al. [69], $\mathrm{D}=0.6 \mathrm{~mm}$; ' Di Miceli Raimondi et al. [70], D = $0.3 \mathrm{~mm}$; $\mathbf{\otimes}$ Bai et al. [10], D = $0.5 \mathrm{~mm}$; $\bullet \mathrm{Li}$ and Angeli [72], D = $0.6 \mathrm{~mm}$; Matsuoka et al. [73], $\mathrm{D}=0.5 \mathrm{~mm} ; \stackrel{\wedge}{\wedge}$ He et al. [84], $\mathrm{D}=0.5 \mathrm{~mm}$.

Further, the flow pattern map of Zhang et al. [12] takes into consideration different powers of Reynolds and Capillary numbers and also claim to have a good fit of the literature.

\subsection{CFD Studies of Influence of Flow Patterns on Transport Property}

In this section, we investigate the mass transfer studies carried out by various researchers. In this section, the approaches available in the published literature for solving 
coupled equations have been presented. They are a. Moving boundary method and $b$. Front capturing method. Table 6 provides the geometric details and operating parameters of the research works while Table 7 provides details of CFD softwares, mesh, methods used for the research works considered.

A typical schematic of the moving boundary approach has been shown in Figure 14 The velocity of the moving wall is same as the slug velocity. Equal stress condition across the interface is considered for the momentum. Convection diffusion equations are solved for each phase. No flux boundary conditions is implemented across moving walls while the flux continuity and thermodynamic equilibrium boundary conditions are implemented with the concentration equations.

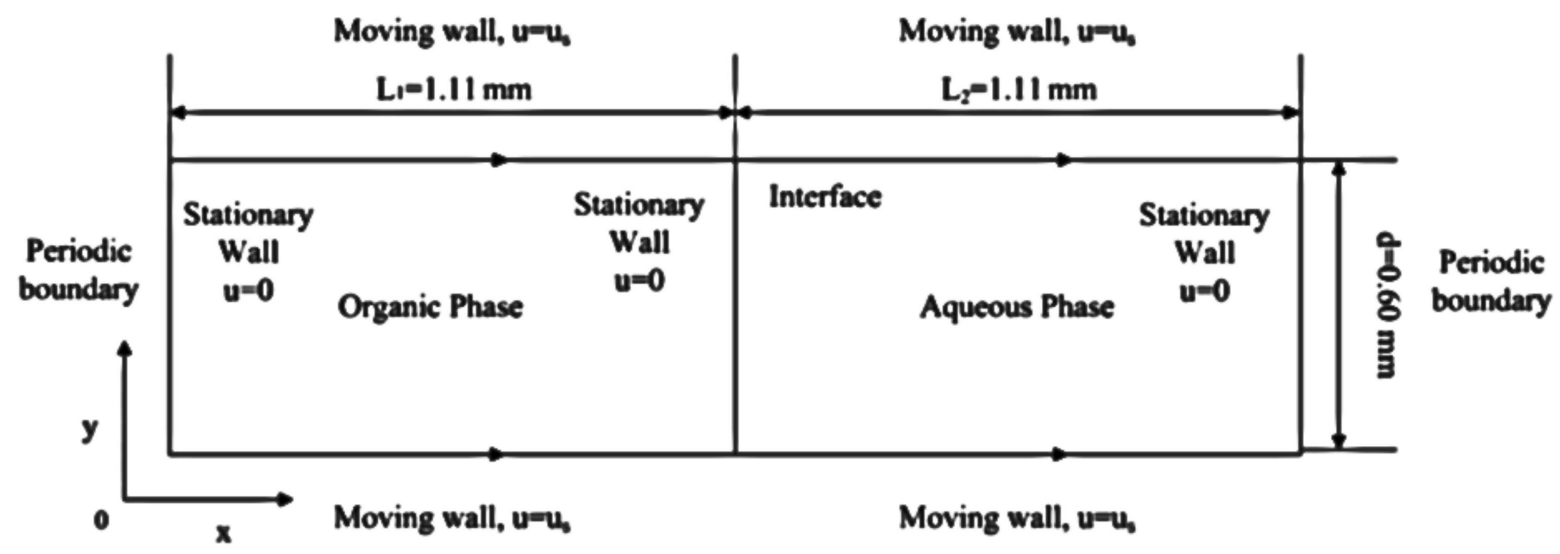

Figure 14. Schematic of moving boundary approach domain for CFD simulations taken from Zhang et al. [86].

To evaluate the VMTC, the simulation process decoupled the hydrodynamics of twophase flow from the mass transfer phenomena and was then divided into two steps. First, the steady-state flow field was established, considering the velocity to be time-invariant. Then, all the components in the solution were initialized in the organic and aqueous phases, respectively, and the flow time was reset to zero. The mass transfer equations were calculated with a time step of $0.001 \mathrm{~s}$ and 10 iterations at each time step by analysing data obtained with different time steps and iterations. For the initial conditions, the flow field at $\mathrm{t}=0 \mathrm{~s}$ calculated in the first step of the computational procedure is the steady-state flow field. Since species 1 is only patched to a certain concentration value in phase 1 , the appropriate initial and final boundary conditions of the concentration field are provided.

Many industrial separation processes occur in fluid-fluid systems including droplets/ bubbles in a continuous phase (e.g., solvent extraction, gas scrubbing, waste water treatment in bio reactors). For these processes interfacial mass transfer represents a crucial phenomenon. To describe it properly, a coupled problem including momentum and mass transport at and around moving interfaces must be solved. Such problems are very difficult, since the deformation of the interface influences interfacial mass transfer related to the handling of boundary conditions at the moving interface. Due to the assumption of the thermodynamic equilibrium, a concentration jump appears at the interface which is numerically demanding and difficult to implement into the front capturing methods. Besides, the component flux continuity should also be fulfilled at the interface. There are just few papers dedicated to this problem.

Bothe et al. [87] used the VOF method to model a gas-liquid system (air bubbles rising in water). They transformed the mass transfer equation to

$$
\frac{\partial \widetilde{C}}{\partial t}+\vec{u} \cdot \nabla \widetilde{C}=D \nabla \widetilde{C}
$$


Table 6. Literature review of research work for coupled hydrodynamics and mass transfer in microchannels: Experimental details.

\begin{tabular}{|c|c|c|c|c|c|c|c|c|c|c|c|}
\hline \multirow[t]{2}{*}{ Authors } & \multicolumn{3}{|c|}{ Channel Details } & \multicolumn{4}{|c|}{ Type of Study } & \multirow[t]{2}{*}{$\begin{array}{l}\text { Parameters } \\
\text { Varied }\end{array}$} & \multirow[t]{2}{*}{$\begin{array}{c}\text { Output } \\
\text { Parameters }\end{array}$} & \multirow[t]{2}{*}{ VMTC, $1 / \mathrm{s}$} & \multirow{2}{*}{$\begin{array}{c}\text { Dimensionless } \\
\text { Number and } \\
\text { Range }\end{array}$} \\
\hline & $\begin{array}{l}\text { Geometry } \\
\text { Type }\end{array}$ & $\begin{array}{l}\text { Channel } \\
\text { Diame- } \\
\text { ter }\end{array}$ & $\begin{array}{l}\text { Channel } \\
\text { Length } \\
(\mathrm{mm})\end{array}$ & $\begin{array}{c}\text { Flow } \\
\text { Rate/Velocity }\end{array}$ & $\begin{array}{l}\text { Experimental/ } \\
\text { CFD }\end{array}$ & System & $\begin{array}{l}\text { Flow } \\
\text { Regime }\end{array}$ & & & & \\
\hline $\begin{array}{l}\text { Kashid } \\
\text { et al. [65] }\end{array}$ & $\begin{array}{l}\text { Micro- } \\
\text { channel }\end{array}$ & $0.5 \times 0.5$ & 2 & $\begin{array}{l}3 \mathrm{~mm} / \mathrm{s} \text { to } \\
16 \mathrm{~mm} / \mathrm{s}\end{array}$ & CFD simulation & $\begin{array}{c}\text { Reactive system: } \\
\text { Kerosene-acetic acid-water; } \\
\text { Non-reactive system: } \\
\text { Water-succinic } \\
\text { acid-nbutanol }\end{array}$ & Slug flow & $\begin{array}{l}\text { time, flow } \\
\text { speed, slug } \\
\text { length }\end{array}$ & $\begin{array}{l}\text { Flow patterns, } \\
\text { VMTC, } \\
\text { concentration } \\
\text { profiles }\end{array}$ & $0.12-0.2 \mathrm{~s}^{-1}$ & NA \\
\hline $\begin{array}{l}\text { Gómez- } \\
\text { Pastora } \\
\text { et al. [88] }\end{array}$ & $\begin{array}{c}\text { Y- } \\
\text { microchannels }\end{array}$ & $\begin{array}{l}0.2 ; 0.04 \\
\quad 0.16\end{array}$ & 2 & $\begin{array}{l}1 \mathrm{~mm} / \mathrm{s} \text { to } \\
20.1 \mathrm{~mm} / \mathrm{s}\end{array}$ & $\begin{array}{l}\text { Experimental } \\
\text { and CFD }\end{array}$ & $\begin{array}{l}\text { Flourescin sodium salt in } \\
\text { water-deionized water }\end{array}$ & Stratified flow & $\begin{array}{l}\text { Inlet velocity; } \\
\text { width to } \\
\text { height ratio, } \\
\text { phase ratio }\end{array}$ & $\begin{array}{l}\text { Seperation factor, } \\
\text { flow patterns }\end{array}$ & NA & $\begin{array}{c}\text { Low Reynolds } \\
\text { number }\end{array}$ \\
\hline $\begin{array}{l}\text { Di Miceli } \\
\text { Raimondi } \\
\text { et al. [89] }\end{array}$ & $\begin{array}{l}\text { Square } \\
\text { micro- } \\
\text { channel }\end{array}$ & $\begin{array}{l}0.06- \\
0.96\end{array}$ & 100 & & CFD simulation & $\begin{array}{l}\text { Non-reactive system: } \\
\text { Water-nbutanol }\end{array}$ & Slug flow & $\begin{array}{l}\text { Reynolds } \\
\text { number, } \\
\text { residence time }\end{array}$ & $\begin{array}{c}\text { VMTC, } \\
\text { concentration } \\
\text { profiles }\end{array}$ & $0.05-10 \mathrm{~s}^{-1}$ & $\begin{array}{l}\text { Capillary } \\
\text { number, } \\
\text { Reynolds } \\
\text { number }\end{array}$ \\
\hline $\begin{array}{l}\text { Cito et al. } \\
\text { [90] }\end{array}$ & $\begin{array}{l}\text { Rectangular } \\
\text { micro- } \\
\text { channel }\end{array}$ & $<1$ & 10 & & CFD simulation & Fluid with SC $=1000$, water & Slug flow & Time & $\begin{array}{c}\text { Flow patterns, } \\
\text { Sherwood number, } \\
\text { wall mass transfer } \\
\text { rate }\end{array}$ & & $\begin{array}{c}\text { Reynolds } \\
\text { number, 1-500; } \\
\text { Sherwood } \\
\text { number }\end{array}$ \\
\hline $\begin{array}{l}\text { Tsaoulidis } \\
\text { and } \\
\text { Angeli } \\
\text { [82] }\end{array}$ & $\begin{array}{l}\text { Micro- } \\
\text { capillary }\end{array}$ & $0.5-2$ & $\begin{array}{l}10,000- \\
31,500 \\
\mathrm{~mm}\end{array}$ & & $\begin{array}{l}0.117-5.67 \\
\mathrm{~mL} / \mathrm{min}\end{array}$ & $\begin{array}{l}\text { Experimental and } \\
\text { Numerical }\end{array}$ & $\begin{array}{c}\text { Nitric } \\
\text { acid-UO2-TBP } \\
\text { (IL) }\end{array}$ & Slug flow & $\begin{array}{l}\text { Residence time, } \\
\text { mixture velocity, }\end{array}$ & $\begin{array}{l}\text { Extraction } \\
\text { efficiency, } \\
\text { VMTC }\end{array}$ & $0.049-0.29 \mathrm{~s}^{-1}$ \\
\hline $\begin{array}{l}\text { Zhang } \\
\text { et al. [86] }\end{array}$ & $\begin{array}{l}\text { Circular } \\
\text { capillary }\end{array}$ & 0.6 & 2.22 & & CFD simulation & $\begin{array}{c}\text { Reactive system: } \\
\text { Water (NaOH)-aceticacid- } \\
\text { nbutanol }\end{array}$ & Slug flow & $\begin{array}{l}\text { Time, vertical } \\
\text { distance }\end{array}$ & $\begin{array}{l}\text { Enhancement } \\
\text { factor, } \\
\text { concentration } \\
\text { profiles, flow } \\
\text { patterns, VMTC, } \\
\text { velocity profiles }\end{array}$ & $0.1-0.3 \mathrm{~s}^{-1}$ & $\begin{array}{l}\text { Hatta number } \\
\quad(0.32)\end{array}$ \\
\hline $\begin{array}{l}\text { Ramji and } \\
\text { Puspa- } \\
\text { vanam, } \\
\text { [91] }\end{array}$ & $\begin{array}{l}\text { Rectangular } \\
\text { microchan- } \\
\text { nel }\end{array}$ & NA & NA & NA & CFD simulation & $\begin{array}{l}\text { Viscosity ratio, density } \\
\text { ratio, diffusivity ratios; } \\
\text { water-acetone-toluene } \\
\text { system for model } \\
\text { validation with } \\
\text { experiments in literature }\end{array}$ & Slug flow & $\begin{array}{l}\text { Viscosity ratio; } \\
\text { Reynolds } \\
\text { number; slug } \\
\text { holdup }\end{array}$ & $\begin{array}{l}\text { Flow patterns, } \\
\text { velocity, } \\
\text { concentration } \\
\text { profiles }\end{array}$ & NA & $\begin{array}{c}\text { Reynolds } \\
\text { number, } 1-100 \text {, } \\
\text { Peclet number } \\
1-5000\end{array}$ \\
\hline
\end{tabular}


Table 7. Literature review of research work for hydrodynamics and mass transfer in micro-channels: CFD Details.

\begin{tabular}{|c|c|c|c|c|c|c|c|c|c|c|}
\hline Authors & & & CFD Details & & & & Software Used & Assumptions & Limitations & Findings \\
\hline & $\begin{array}{l}\text { Single/Two } \\
\text { Phase }\end{array}$ & Dimension (D) & Grid Details & $\begin{array}{c}\text { VOF/Leve-Set } \\
\text { Method }\end{array}$ & $\begin{array}{l}\text { with/without } \\
\text { Mass Transfer }\end{array}$ & $\begin{array}{l}\text { Steady/Unsteady } \\
\text { State }\end{array}$ & & & & \\
\hline $\begin{array}{l}\text { Kashid et al. } \\
\text { [65] }\end{array}$ & Two phase & $2 \mathrm{D}$ & $\begin{array}{l}640 \times 128 \\
\text { elements }\end{array}$ & NA & $\begin{array}{l}\text { with mass } \\
\text { transfer with } \\
\text { model of Yang } \\
\text { and Mao [92] }\end{array}$ & $\begin{array}{l}\text { Unsteady state } \\
\text { governing } \\
\text { equations with } \\
\text { convection- } \\
\text { diffusion } \\
\text { equations } \\
\end{array}$ & $\begin{array}{l}\text { FEATFLOW } \\
\text { open source } \\
\text { software }\end{array}$ & $1,2,3,4,5$ & $1,2,3$ & 1,2 \\
\hline Cito et al. [90] & Two phase & $2 \mathrm{D}$ & $125 \times 100$ & $\begin{array}{l}\text { Level-Set } \\
\text { method }\end{array}$ & $\begin{array}{l}\text { with mass } \\
\text { transfer with } \\
\text { model of Yang } \\
\text { and Mao [92] }\end{array}$ & $\begin{array}{l}\text { Unsteady state } \\
\text { governing } \\
\text { equations with } \\
\text { convection- } \\
\text { diffusion } \\
\text { equations } \\
\end{array}$ & JADIM code & 1,3 & 4 & 3,4 \\
\hline $\begin{array}{c}\text { Di Miceli } \\
\text { Raimondi et al. } \\
\text { [89] }\end{array}$ & Two phase & $2 \mathrm{D}$ & 47,187 & NA & $\begin{array}{l}\text { with mass } \\
\text { transfer }\end{array}$ & $\begin{array}{l}\text { Unsteady state } \\
\text { governing } \\
\text { equations with } \\
\text { convection- } \\
\text { diffusion } \\
\text { equations }\end{array}$ & $\begin{array}{l}\text { Fluent } \\
\text { commercial } \\
\text { software }\end{array}$ & 1,3 & 1,5 & $5,6,7,8$ \\
\hline $\begin{array}{c}\text { Tsaoulidis and } \\
\text { Angeli [82] }\end{array}$ & Two phase & $\begin{array}{c}2 \mathrm{D} \\
\text { axisymmetric }\end{array}$ & $\begin{array}{l}\text { Individual cell } \\
\text { size is } 32 \mu \mathrm{m} \\
\text { time step } 0.05 \mathrm{~s}\end{array}$ & None & $\begin{array}{l}\text { with mass } \\
\text { transfer }\end{array}$ & 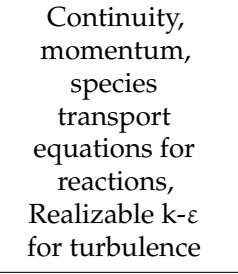 & & $1,4,5$ & $1,6,7$ & 9 \\
\hline Zhang et al. [86] & Two phase & $2 \mathrm{D}$ & $\begin{array}{c}\text { Each grid cell of } \\
\text { size } 10 \mu \mathrm{m} \text { and } \\
\text { fine near the } \\
\text { boundaries } 2 \\
\mu \mathrm{m}\end{array}$ & NA & $\begin{array}{l}\text { with mass } \\
\text { transfer, both } \\
\text { boundary } \\
\text { conditions (flux } \\
\text { continuity and } \\
\text { thermodynamic } \\
\text { equilibrium) }\end{array}$ & $\begin{array}{l}\text { Unsteady state } \\
\text { governing } \\
\text { equations with } \\
\text { convection- } \\
\text { diffusion } \\
\text { equations for } \\
\text { both phases }\end{array}$ & Ansys Fluent & 1 & 1 & $10,11,12$ \\
\hline
\end{tabular}


Table 7. Cont.

\begin{tabular}{|c|c|c|c|c|c|c|c|c|c|c|}
\hline Authors & & & CFD Details & & & & $\begin{array}{c}\text { Software } \\
\text { Used }\end{array}$ & Assumptions & Limitations & Findings \\
\hline $\begin{array}{c}\text { Gómez- } \\
\text { Pastora et al. } \\
\text { [88] }\end{array}$ & Two phase & $2 \mathrm{D}$ & $400 \times 100$ & VOF & $\begin{array}{l}\text { Mass transfer } \\
\text { only due to } \\
\text { concentration } \\
\text { gradient }\end{array}$ & $\begin{array}{l}\text { Unsteady state } \\
\text { governing } \\
\text { equations with } \\
\text { convection- } \\
\text { diffusion } \\
\text { equations }\end{array}$ & $\begin{array}{c}\text { FLOW 3D } \\
\text { commercial } \\
\text { software }\end{array}$ & 1 & 1 & $13,14,15$ \\
\hline $\begin{array}{c}\text { Ramji and } \\
\text { Puspavanam, } \\
{[91]}\end{array}$ & Two phase & $2 \mathrm{D}$ & $202 \times 101$ & NA & $\begin{array}{c}\text { Dimensionless } \\
\text { Transient } \\
\text { Mass transfer }\end{array}$ & $\begin{array}{l}\text { Dimensionless } \\
\text { Unsteady state } \\
\text { governing } \\
\text { equations with } \\
\text { convection- } \\
\text { diffusion } \\
\text { equations }\end{array}$ & $\begin{array}{l}\text { In-house code } \\
\text { for solving } \\
\text { dimensionless } \\
\text { governing } \\
\text { equations and } \\
\text { interface } \\
\text { movement }\end{array}$ & $1,4,5,6,7$ & 1 & 16,17 \\
\hline
\end{tabular}

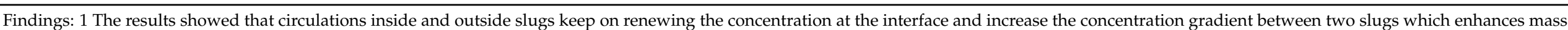

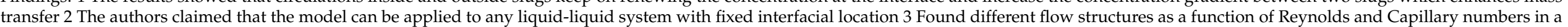

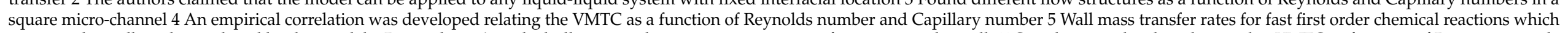

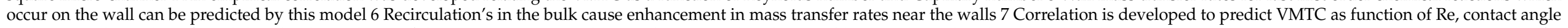

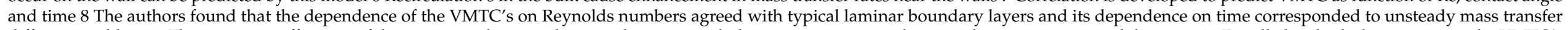

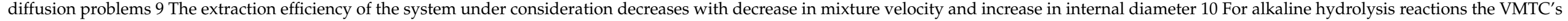

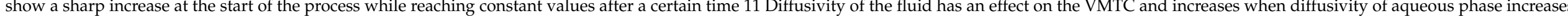

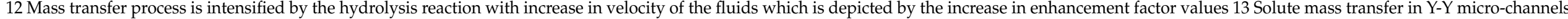

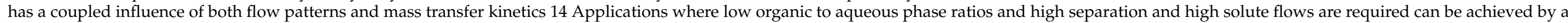

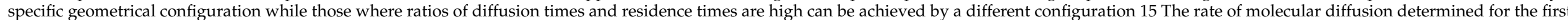

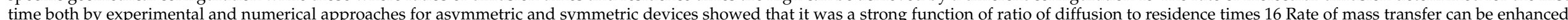

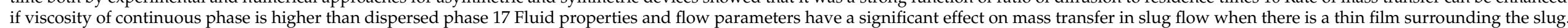

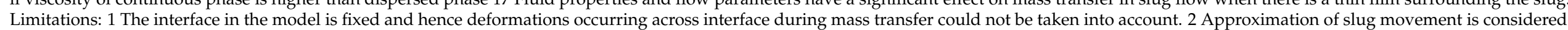

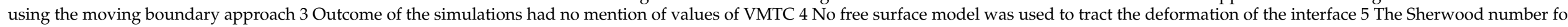

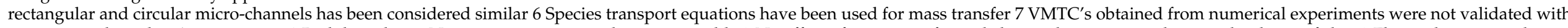

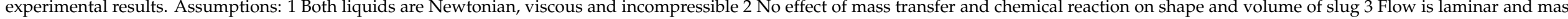

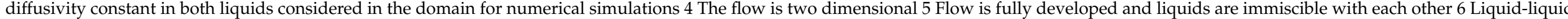

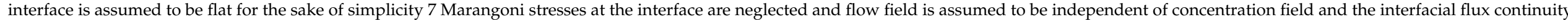
boundary condition to 


$$
D_{l} \nabla \widetilde{C}_{l} \cdot n=H D_{g} \nabla \widetilde{C}_{g} \cdot n
$$

where $n$ is the unit vector normal to the interface, $C$ is concentration, $\vec{u}$ is velocity, $D$ is molecular diffusivity and

$$
\widetilde{C}=\left\{\begin{array}{c}
C_{l} \\
C_{g} / H
\end{array}\right.
$$

where indices $l$ and $g$ denote gas and liquid phases and $H$ is the distribution coefficient (Henry's constant).

Yang and Mao, [92] carried out CFD simulations using the LS method for a rising droplet in a continuous liquid phase (water-succinic acid-butanol). The equation for mass transfer was modified in their work and is given below

$$
\frac{\partial \hat{C}}{\partial t}+\hat{u} \cdot \nabla \hat{C}=\nabla \cdot(\hat{D} \nabla \hat{C})
$$

where

$$
\begin{gathered}
\hat{t}(\varnothing)=\left\{\begin{array}{c}
\sqrt{H} t \text { if } \varnothing \geq 0 \\
t / \sqrt{H} \text { if } \varnothing \leq 0
\end{array}\right. \\
\hat{D}(\varnothing)=\sqrt{H} D_{2}+\left(D_{1} / \sqrt{H}-\sqrt{H} D_{2}\right) H_{\varepsilon}(\varnothing) \\
\hat{u}(\varnothing)=\sqrt{H} u+(u / \sqrt{H}-\sqrt{H} u) H_{\mathcal{\varepsilon}}(\varnothing)
\end{gathered}
$$

where

$$
\hat{C}=\left\{\begin{array}{c}
C_{l} \\
C_{g} / H
\end{array}\right.
$$

Here, $H$ is the distribution for the liquid-liquid system considered and $H_{\varepsilon}(\varnothing)$ is the regularized Heaviside function to avoid the numerical instabilities at the interface. It is given by

$$
H_{\varepsilon}(\varnothing)=\left\{\begin{array}{c}
0 \text { if } \varnothing<-\varepsilon \\
\frac{1}{2}\left(1+\frac{\varnothing}{\varepsilon}+\sin (\pi \varnothing / \varepsilon) / \pi\right) \text { if }|\varnothing| \leq \varepsilon \\
1 \text { if } \varnothing>\varepsilon
\end{array}\right.
$$

Haroun et al. [93] suggested a VOF-based modelling approach for reactive absorption systems. They considered the film flow of a liquid flowing along a corrugated surface in counter-current with the laminar gas stream. The mass transport equation has been modified to:

$$
\frac{\partial C_{i}}{\partial t}+\nabla \cdot\left(\vec{u} C_{i}\right)=\nabla \cdot\left(D_{i} \nabla C_{i}+\Phi_{i}\right)+W_{i}
$$

where

$$
\Phi_{i}=\left(D_{j} \frac{C_{j}\left(1-H_{j}\right)}{f+H_{j}(1-f)} \nabla f\right)
$$

Here, $j$ indicates component number, $f$ is volume fraction, $W_{j}$ is the production term related to chemical reaction. Haroun et al. [93] claimed that Equations (21) and (22) account for the jump conditions at the smeared-out interface, where the volume fraction gradients are usually very steep.

Kenig et al. [94] performed CFD simulations with coupled mass and momentum equations were solved with the incorporation of the boundary conditions in the concentration equation.

$$
\begin{gathered}
\frac{\partial C_{d}}{\partial t}+\vec{u} \cdot \nabla\left(C_{d}\right)=\nabla \cdot\left(D_{d} \nabla C_{d}\right)+\alpha_{1}\left(D_{c} \frac{\partial C_{c}}{\partial n}-D_{d} \frac{\partial C_{d}}{\partial n}\right) \\
\frac{\partial C_{c}}{\partial t}+\vec{u} \cdot \nabla\left(C_{c}\right)=\nabla \cdot\left(D_{c} \nabla C_{c}\right)+\alpha_{1}\left(C_{c}-\frac{C_{d}}{H_{D}}\right)
\end{gathered}
$$


where, subscript $c$ denotes continuous phase while subscript $d$ denotes dispersed phase, $H_{D}$ denotes the distribution coefficient, $\alpha_{1}, \alpha_{2}$ are parameters, $n$ is the unit vector normal to the interface. The values of $\alpha_{1}, \alpha_{2}$ are adjusted in such a way that the boundary conditions are solved only at the interface. The authors have considered a droplet rising in an aqueous phase in a water-acetic-acid-toluene system and mass transfer from toluene to water.

Two phase simulations with and without mass transfer have been carried out. CFD simulations using a mass transfer model that predicts mass transfer across the interface were carried out using COMSOL 3.5a. The model has been validated with liquid-liquid and gas-liquid systems with satisfactory qualitative results.

Following are the boundary conditions for moving boundary approach:

1. Axial and radial velocities of the walls are equal to slug/plug velocity

2. No slip boundary condition at channel wall

3. Equal stresses at the interfaces between two phases

4. Flux continuity boundary condition at the interface

5. Zero flux set at the channel wall

6. Periodic boundary condition to satisfy flux continuity at the interface.

In Section 2.2, CFD studies were discussed in which governing equations for mass and momentum were solved with interface tracking techniques like VOF. However, the most important parameter for transport property (mass transfer) is the VMTC and hence mass transfer from dispersed phase to continuous phase should be obtained by solving concentration governing equations. However, boundary conditions of thermodynamic equilibrium and flux continuity as given by Equations (2) and (3) should also need to be incorporated while the system of equations is being solved. The approaches mentioned in the previous subsection have been used by a few researchers and will be discussed in this section. Details of investigations are provided in Tables 6 and 7.

Kashid et al. [65] performed simulations with the model provided by Yang and Mao [92] and used the VOF method for defining the interface. The authors observed internal circulations that keep on renewing at interface and increase the concentration gradient between two slugs which enhances the rate of mass transfer. The authors claimed that the model can be used for any liquid-liquid system with a fixed interface location. No free surface model equations were used for tracking the interface. To summarize, the authors have used the concept of moving boundaries for their numerical investigations.

Di Miceli Raimondi [89] have solved two dimensional simulations using their own inhouse code. The simulations were carried out in two steps. First, the hydrodynamic behaviour of the system is computed by means of the code. In the second step the concentration field of this solute present in the dispersed phase is computed by a code in Matlab 7.4. The numerical method used by the authors is an interface capturing technique without any interface reconstruction. The authors observed three flow structures (a) internal vortices in both continuous and dispersed phases and thin film that wets the wall, (b) several recirculation nodes inside droplets and (c) without any recirculation loops in continuous phase since droplet is not confined enough. The flow structures were found to be a function of Reynolds and capillary numbers. Several simulations were performed for different dispersed phase velocity, channel width, dispersed phase holdup. A correlation has been developed for the computation of VMTC based on the data. The authors have compared the correlation with other correlations $[95,96]$ and the predictions were in good agreement.

Zhang et al. [86] performed CFD simulations to predict mass transfer characteristics with and without alkaline hydrolysis reactions during slug flow in micro-channels. The species concentration equation was used for computing the concentration. The moving boundaries approach was used. The predicted VMTC values were compared with experimental values and a close agreement was observed. The authors claimed that the model could be applied to various liquid-liquid systems with fixed interfaces. The authors also claimed that this model can be coupled with free surface models to capture complex hydrodynamics near the interface. 
Cito et al. [90] studied wall mass transfer rates generated by capillary driven flow in a micro-channel. Simulations were performed for 2D rectangular and circular microchannels. The effect of Reynolds number, channel geometry and contact angle on average wall mass transfer rates were observed. A correlation for Sherwood number Sherwood and Wei [97] relating the above parameters was developed from the simulated data. The effect of wall curvature was considered negligible in the present work due to high value of Schmidt number. For $\operatorname{Re}<500$ the Sherwood number had a weak dependence on contact time. The dependence on time corresponds to unsteady mass diffusion problems.

Tsaoulidis and Angeli, [82] carried out experimental investigations for extraction of Uranium in straight microchannels. The internal diameter was varied from $(0.5 \leq \mathrm{D} \leq 2 \mathrm{~mm})$. The authors found the VMTC in small channels was in the range 0.049 to $0.29 \mathrm{~s}^{-1}$. A correlation for VMTC as a function of Re, Ca and (Internal dia (ID)/length of channel $(D / L)$ ) was developed and predictions were compared with the experimental measurements as well as other models available in the literature. The authors also investigated the effect of input parameters like internal diameter and mixture velocity on efficiency and found that output parameters like efficiency decreased with increase in ID. The authors have also carried out numerical simulations with commercial software COMSOL 4.3. The domain taken by the authors is a dispersed elongated structure which the authors mention as plug (instead of the general definition of slug by previous authors) while the surrounding continuous phase fluid is mentioned as the slug. Momentum and continuity equations were solved for this domain along with convection-diffusion equations. The interface is considered stationary and a moving wall boundary condition has been provided. The numerical results for the velocity fields were compared with velocity patterns from Particle Image Velocimetry (PIV). Images captured by High Speed camera were used to calculate output parameters like the film thickness, length of unit cell, plug length, plug velocity. The data generated from the images were used as boundary conditions of numerical simulations. Extraction efficiencies were compared with numerical results and a good agreement was obtained.

Gómez-Pastora et al. [88] performed experimental and numerical investigations of solute mass transfer in Y-Y micro-channels as a function of coupled influence of both flow patterns and mass transfer kinetics. The influence of ratio between residence and diffusion times and volumetric ratio between fluid phases was determined for 3 geometric variations Symmetric device: $Y$ junction inlet and outlet with equal inlet and outlet diameters for phase 1 and phase 2. Configuration 1: Y junction inlet and outlet with inlet and outlet diameter of phase 2 four times higher than the ones of phase 13 . Configuration 2: $\mathrm{Y}$ junction inlet and outlet with inlet and outlet diameter of phase 1 four times higher than the ones of phase 2. Figure 15 shows the schematic of the micro-channels used by the authors. Two factors (a) concentration factor (defined as the ratio of outlet concentration in phase 2 to outlet concentration of solute in phase 1) and separation factor (similar to conversion and defined as ratio of difference between inlet and outlet concentration of phase 1 to inlet concentration of phase 1) were used to quantify performance. The authors found that separation factor influenced the values of solute concentration in both phases which influences mass flow of solute and channel outlet. Two configuration of Y-Y channels were suggested for different applications. The authors recommended that systems with separation factor less than 1 can be used for applications where high solute flows are required (configuration 1 by authors can be used) while separation factors greater than 1 can be used for processes where high concentration factors are needed (configuration 2 can be used). 


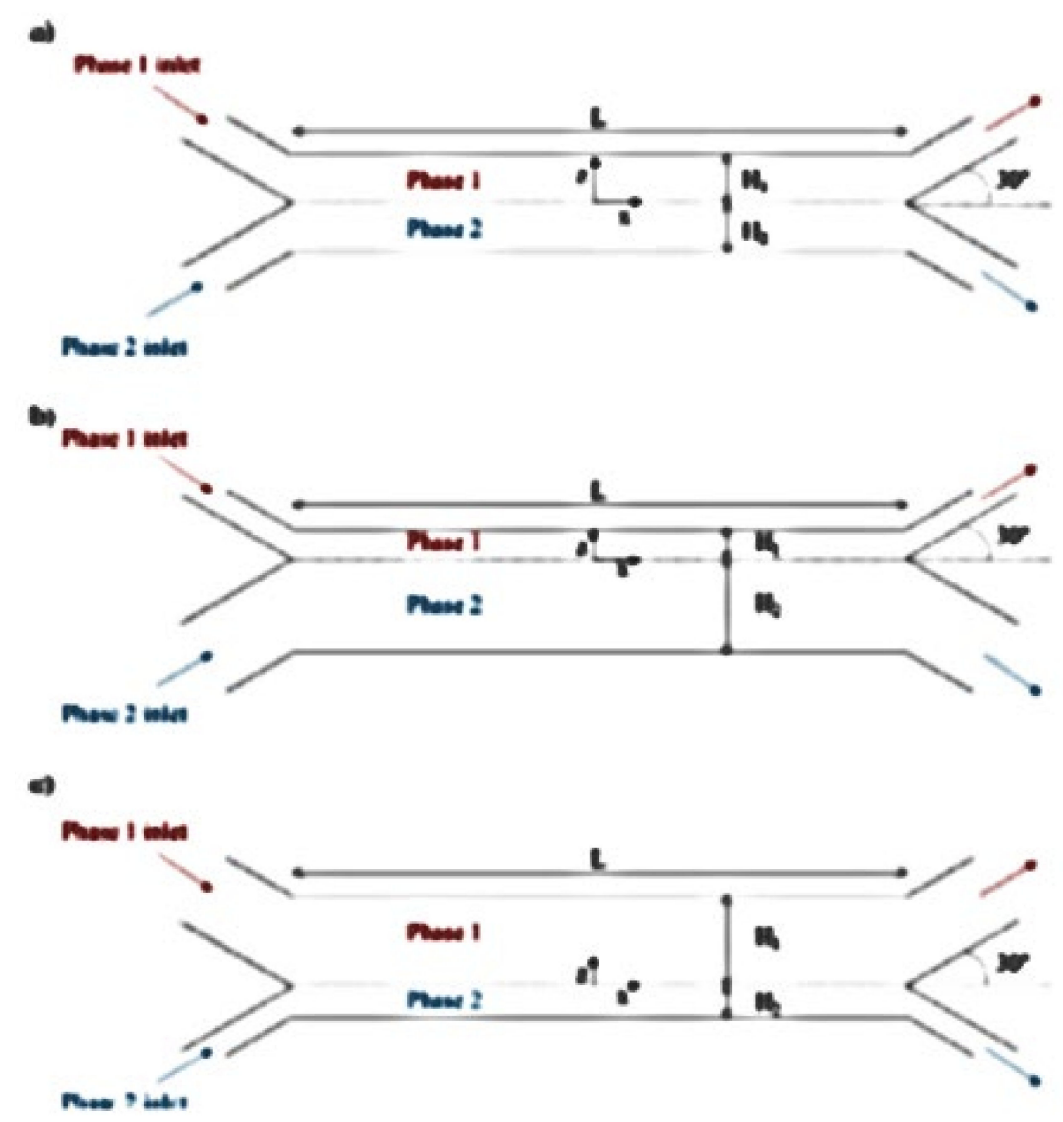

Figure 15. (a) Symmetric device (b) Configuration 1: Asymmetric device $\mathrm{H}_{2}=4 \mathrm{H}_{1}$ (c) Configuration 2: Asymmetric device $\mathrm{H}_{1}=4 \mathrm{H}_{2}$. Reproduced with permission from Gomez-Pastora et al. [88].

\section{Influence of Flow Patterns on Transport Property: Heat Transfer}

In the present section we briefly report the experimental and numerical studies on two phase liquid-liquid heat transfer. Liquid-liquid two phase flow is a preferred method over gas-liquid two phase flow due to the dispersed phase liquid having higher thermal conductivity and hence higher heat transfer coefficients. Further, in the slug flow regime, the continuous phase flow is disrupted by the presence of the dispersed phase which contributes to enhancement of heat transfer coefficient. Also, another reason for enhancement is the recirculations inside the dispersed phase. Major parameters influencing liquid-liquid two phase flow deals with influence of different parameters like fluid properties and geometrical dimensions.

\subsection{Experimental Studies of Heat Transfer in Microchannels Involving Liquid-Liquid Two Phase Flow}

Though plenty of studies in single phase systems in microchannels have been reported [4], a few experimental studies for two phase liquid-liquid systems have been carried out by researchers [98-100]. Systems used were water-light mineral [98]; siliconoilwater [99] and Water-hexadecane [100]. All the authors have observed slug flow in their investigations. Asthana et al. [98] have carried out experimental investigations in $100 \times 100 \mu \mathrm{m}$ six turn serpentine microchannel of square cross section. Increase in heat transfer due to two phase flow (water-mineral oil) of 4 times compared to pure water have been observed. The authors also observed a significant increase in pressure drop due to heat transfer. Giolla Eain et al. [99] studied the effect of decreasing slug lengths and increase in film thicknesses on heat transfer rates in a $1.5 \mathrm{~mm}$ circular channel under constant wall heat flux boundary conditions in an Re range $2.3<\operatorname{Re}<92.1$. The authors observed that heat transfer increased by decrease in slug lengths while decreased by increase in film thickness. Correlations for both heat transfer and film thickness as a function of dimension- 
less numbers (Ca and We) were proposed by the authors. Dai et al. [100] also carried out experimental investigations in a vertical $2 \mathrm{~mm}$ circular microchannel under constant wall heat flux boundary conditions in an Re range $15<\operatorname{Re}<48$. The authors found an empirical correlation for the same. Abdollahi et al. [101] carried out both experimental and numerical investigations in microchannels with hydraulic diameter of $2 \mathrm{~mm}$, a oil-water system for constant heat flux boundary conditions. The authors determined correlations for friction factor and heat transfer coefficients and found an increase of $700 \%$ in heat transfer rates over single phase flow.

\subsection{CFD Studies of Heat Transfer in Microchannels Involving Liquid-Liquid Two Phase Flow}

A few numerical investigations have also been performed to study two phase flow. Vivekanand and Raju [102] carried out 2D axisymmetric numerical investigations in $100 \mu \mathrm{m}$ channels using the VOF method. The investigation was carried out for both constant wall heat flux and constant wall boundary conditions. The authors observed increase in Nusselt $(\mathrm{Nu})$ number upto $180 \%$ and $210 \%$ increase in two phase as compared to single phase. Urbant et al. [103] have found increase in heat transfer coefficients for water droplets in oil in circular microchannels of diameter $0.1 \mu \mathrm{m}$. The recirculations were seen in both phases resulting in the increase in HTC. Fischer et al. [104] have observed $400 \%$ increase in heat transfer rates for a Water-Silicon Oil system as compared to single phase fluids using 2D axisymmetric geometry of 0.1-1 mm diameter microcapillaries. Che et al. [105] did simulations with 2D geometry for microchannels and found that heat transfer increases with decrease in length of the slugs. Che et al. [106] carried out 3D large eddy simulations (LES) for $0.2-0.8 \mathrm{~mm}$ (characteristic length) microchannels for water-mineral oil system. An increase in $\mathrm{Nu}$ number was observed due to the two phase flow conditions due to recirculations present in both continuous and dispersed phase. Bandara et al. [107] carried out CFD simulations to investigate heat transfer characteristics $(4.9<\operatorname{Re}<21.9)$. The authors concluded that the heat transfer rates depended on the Ca numbers, slug sizes, film thickness and contact angles. The authors used correlations available in the literature (for GL flows) to find the Nu number and concluded that correlations needed to be developed specifically for LL flows. Presently two correlations for $\mathrm{Nu}$ number (one by numerical studies by Dai et al. [100] and other by experimental studies by Giolla Eain et al. [99] exist for LL flows. The equations are given in Table 8.

\subsection{Other Aspects: Film Thickness, Peclet Number Effect, Systems Considered, Scope for Different Geometries}

During heat transfer in two phase LL flows a thin film is formed between the slugs and the walls when flows are in slug flow regime. Techniques used in the literature consist of Micro-PIV [98] and optical macroscopy [99]. The heat transfer rate has an inverse relationship with film thickness and is decreased with an increase in film thikness. Most authors have used in the past the correlations of GL flows in LL flows to determine film thickness until Giolla Eain et al. [99] found a correlation for two phase flows based on their experimental data. The authors defined film thickness in terms of Ca number and We number

$$
\frac{\delta}{R}=0.35(\mathrm{Ca})^{0.35}(\mathrm{We})^{0.1}
$$

In case of rectangular channels, heat transfer from the wall to center of liquid slug is further due to the space between the curvature of the liquid slug and the corners of the rectangular channel since heat transfer in this region occurs due to conduction only. Further, the heat transfer in LL flows will also depend on increase or decrease of flow which will alter the size of the slugs and hence increase heat transfer rates.

Another important parameter affecting heat transfer is the Peclet $(\mathrm{Pe})$ number which is the ratio of heat transfer by convection to that by diffusion. Che et al. [105] in their numerical investigations found that increasing Pe number increases the Nu number but decreases the heat transfer process. 
Table 8. Correlations for HTC's in LL flows.

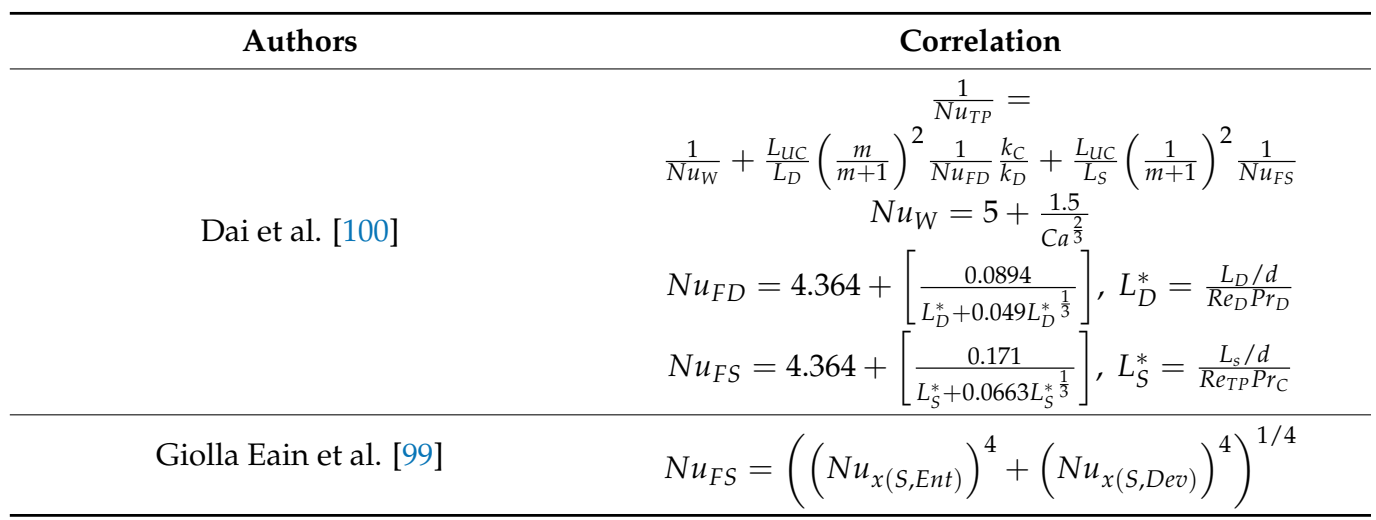

Fluid properties and size and shape of the microchannels would play a vital role in heat transfer in LL flows. The literature review shows that mostly Oil-water systems have been used for both experimental and numerical studies. Shape of the microchannel would have an effect on the heat transfer process as seen in the description of rectangular channels. Further, 3D simulations would give more opportunities for studying the shape of the channels numerically.

\section{Conclusions}

The conclusions are summarized in Figure 16. The brief description is provided as follows:

1. Flow patterns namely parallel, slug, annular, annular-slug, slug-dispersed have been reported by authors but some new patterns like rivulet and serpentine patterns have also been observed for liquid-liquid systems in main channels of microchannels

2. Flow patterns in junctions (cross or T-junctions) are also summarized as tubing, dripping and jetting. Several works are available but a connection between the flow patterns in the junctions and the main channels needs to be made while creation of regime maps

3. Regime maps have been presented by authors with dimensionless numbers like product of Reynolds numbers and Capillary numbers or product of Weber and Ohnesorge numbers. However, there is no consensus on the particular regime maps and no regime map is able to predict the works of the entire literature correctly

4. Pressure drop studies are in the form of experimental investigations and analytical models. The pressure drop models are seen to predict well with the experimental data for similar viscosity systems

5. Few CFD models focusing on flow patterns have been found for liquid-liquid systems. The models have shown good predictive capabilities with experimental results. However, Capillary number plays an important role in the predictions. For certain Capillary numbers the CFD models have been unable to predict the flow patterns as those of experimental observations suggesting more amount of research works to be carried out in this area.

6. Mass transfer studies in experimentation have shown the effect of operating variables and properties and geometric dimensions. VMTC is found to increase with an increase in flow velocity, presence of inerts, presence of surfactants, increase in flow ratio. VMTC however decreases with increase in characteristic channel dimension (like channel width or diameter) for specific channel length.

7. For cases of extraction of rare earths or uranium, the residence times are found to be less than $20 \mathrm{~s}$ which is an order of magnitude less than conventional batch or continuous processes

8. The VMTC's for test systems involving conventional solvents or systems involving IL's or DES's are two orders of magnitude higher than the VMTC's of conventional 
equipment's. However, commercialization needs stacking up of a number of microchannels in series and hence needs substantial research in this direction

9. For reactive systems, the measured MTC's are two to three times the ones predicted by film theory due to the enhancement in mass transfer during reaction

10. CFD studies have been carried out majorly with stationary interfaces with specified slug lengths obtained from experimental measurements. Boundary conditions for the interface are also specified from experimental measurements. In contrast, coupled system of equations involving interface capturing methods, pressure-velocity and concentration equations need to be solved.

11. All investigations in heat transfer studies have shown higher heat transfer rates from $180 \%$ to $700 \%$ as compared to single phase flow. It is important to note that lower sizes $(\sim 0.1 \mathrm{~mm})$ give lower percentage increase in heat transfer rate $(180 \%)$ while higher sizes $(\sim 2 \mathrm{~mm})$ give higher percentage increase in heat transfer rate.

12. Most CFD studies have been carried out in $2 \mathrm{D}$ or $2 \mathrm{D}$ axisymmetric mode while $\mathrm{CFD}$ simulations need to carried out in 3 dimensions to get better insight of qualitative and quantitative results.

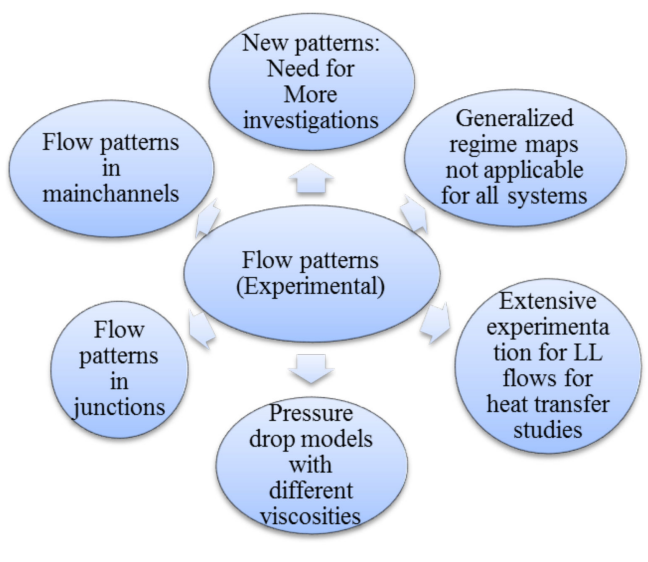

(A)

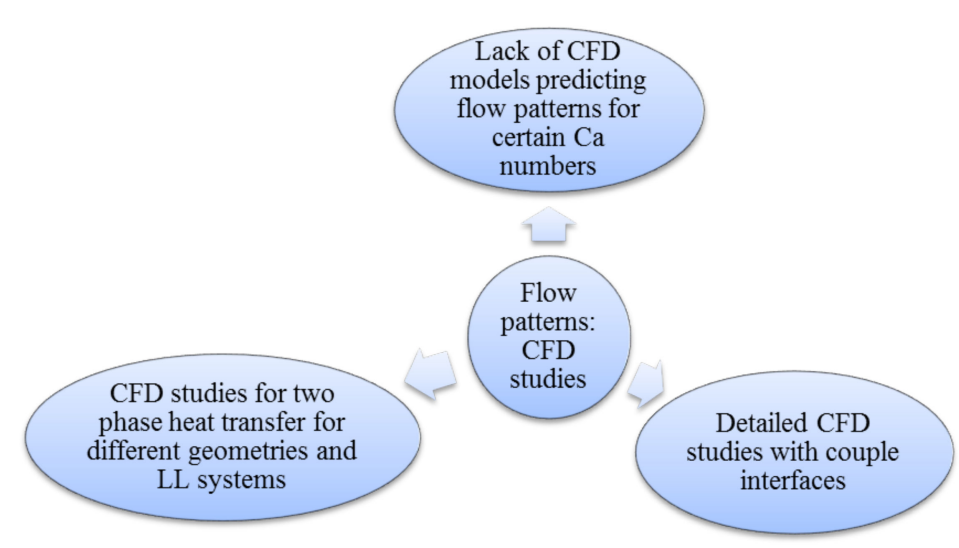

(B)

Figure 16. Summary of conclusions of the review (A) Experimental studies, (B) CFD studies.

\section{Future Scope}

1. Several works have been focused on understanding the flow patterns. Few researchers have focussed on flow patterns at the junctions while many of them have focused on the main channels only. In main channels, few researchers observed new flow patterns which are different than the obvious flow patterns of parallel, slug, annular and dispersed flow or a combination of these. These patterns need to be studied more extensively by research fraternity similar to the work of researchers Yagodnitsyna et al. [7], needs to be taken up by more researchers. Numerical simulations for these cases needs to be carried out which for two phase flows for various systems with different fluid properties and operating parameters and such models need to be validated with the rich experimental data available in the literature both in junctions and main channels

2. Commercial applications need to be found where LLE can be carried out in microchannels. The regime in which such operations would be carried out will pave the way for efficient equipment design. Presently, from the reviewed literature, extraction of rare earth metals seems to be the most promising application that can be commercialized in micro-channels.

3. There have been very extensive and comprehensive studies for predictions of regime maps by some researchers. A few researchers, claim universal regime maps. However, the individual investigations in literature (for reactive and non-reactive systems) for micro-channels does not quite comply with the flow regime maps except the regime 
map by Zhang et al. [12]. This might be due to the use of different material of constructions for experimental investigations. Further, several authors claim combination of different dimensional numbers. One of the recommendations would be to form a consortium of experts for development of comprehensive regime maps which can be used for any system which currently seems to be a challenge. Numerical simulations with the power of volume capturing methods would play a vital role in preparing such universal maps

4. Surprisingly, most of the experimental works compare the VMTC's in micro-channels with conventional equipment's and the VMTCs are two orders of magnitude higher than ones in conventional extractors. But inspite of such various advantages of microchannels, commercial application of micro-channels are not reported in literature. Gaps in commercialization of micro-channel extraction units need to be found and research work needs to be taken up in that direction

5. The advantages of CFD simulations in understanding flow patterns and mass transfer in micro-channels have not be harnessed to its full potential. More number of works of CFD with green solvents like ionic-liquids and Deep Eutetic Solvents (DES) need to be taken up and validated against the experimental results both in terms of hydrodynamics and mass transfer

6. Mass transfer models need to be used for predictions for VMTC's with micro-channels as well for the various systems that have been discussed in the present article (both experimental and two phase CFD simulations). Surprisingly, mass transfer models have not been used extensively for predictions of interfacial area and VMTC's. Softwares like Ansys Fluent/Comsol/in-house-code have been used by authors who have developed CFD models. The surface is however considered constant in most of the cases. Movement of the surface is important to capture the Marangoni instabilities which enhances mass transfer.

7. Very few works in terms of coupled equations of front tracking methods (LevelSet/VOF) with mass transfer models with Navier-Stokes equations exist in the literature for drops or bubbles moving in continuous liquids or liquid films on solid surfaces. However, in these models the distribution coefficient is used as a transformation parameter and thus assumed to be constant. However, in reality, the distribution coefficient depends on state variables and suffers significant changes. Hence, robust mass transfer models also needs to be developed before they can be applied to microchannels for prediction of VMTC's and interfacial areas. Ideally, a comprehensive mathematical model taking account of the interface deformation, interfacial concentration jump and variable distribution coefficient needs to be developed.

8. More test systems need to be studied for understanding heat tranfer rates in liquidliquid systems with a wide range of sizes

9. Higher range of Re numbers need to be considered $(100<\operatorname{Re}<1000)$ for understanding the effect of various parameters on heat transfer rates.

Author Contributions: Conceptualization, A.A.G. and A.B.P.; methodology, A.A.G.; software, None; validation, None; formal analysis, A.A.G.; investigation, A.A.G.; resources, A.A.G.; data curation, A.A.G.; writing—original draft preparation, A.A.G.; writing—review and editing, A.A.G.; visualization, A.A.G.; supervision, A.B.P.; project administration, None; funding acquisition, A.A.G. All authors have read and agreed to the published version of the manuscript.

Funding: This project received no external funding.

Institutional Review Board Statement: Not applicable.

Informed Consent Statement: Not applicable.

Data Availability Statement: Since this is review article the data is taken from the literature.

Conflicts of Interest: The authors declare no conflict of interest. 


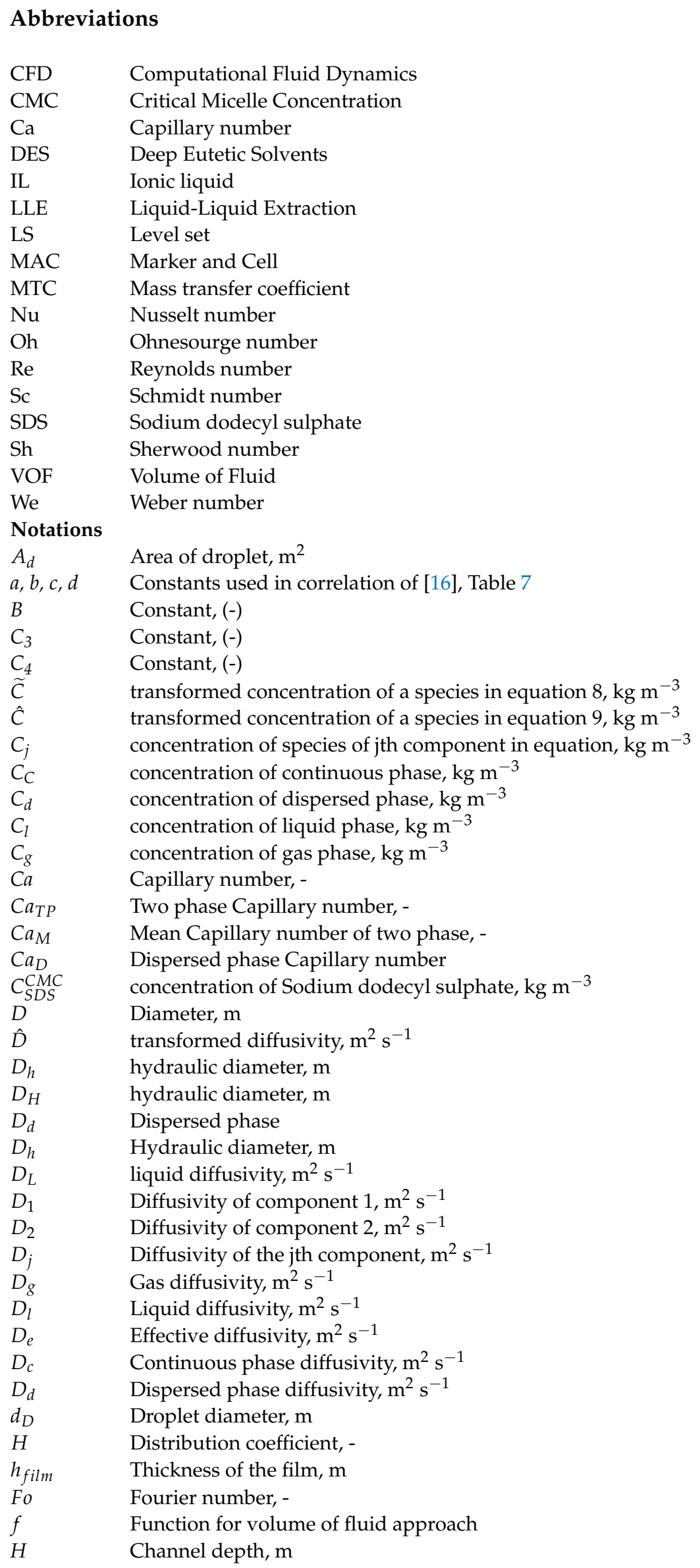




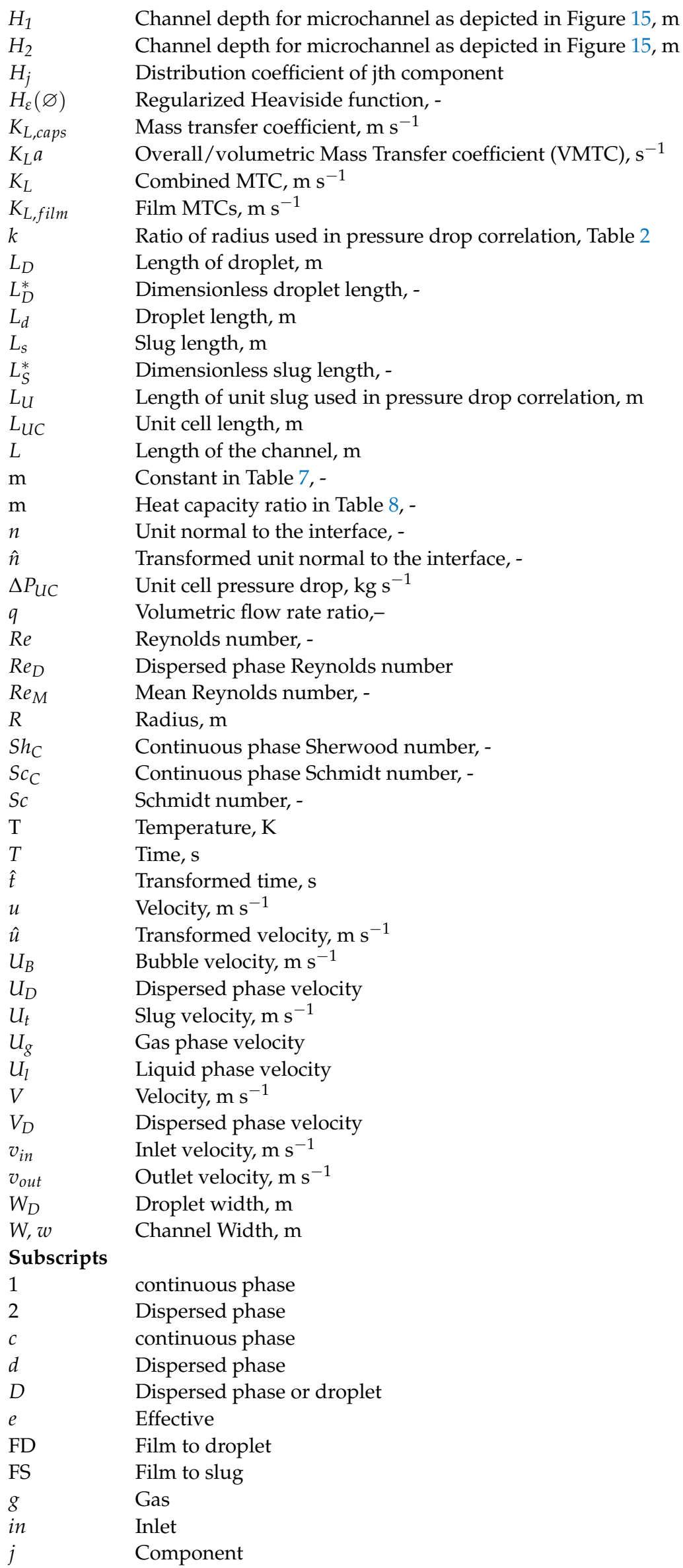




$\begin{array}{ll}l & \text { Liquid } \\ L & \text { MTC } \\ M & \text { Mean } \\ \text { Oil } & \text { Oil } \\ \text { out } & \text { Outlet } \\ R & \text { Residence time } \\ s & \text { Slug } \\ \text { sat } & \text { Saturated } \\ t & \text { Velocity } \\ T P & \text { Two phase } \\ \text { UC } & \text { Unit cell } \\ W & \text { Wall } \\ \text { water } & \text { Water } \\ \text { Greek Symbols } & \\ \alpha & \text { Water phase fraction, - } \\ \beta & \text { Dispersed phase fraction, - } \\ \delta & \text { Film thickness, m } \\ \varepsilon_{L} & \text { Interface thickness in level-set equation, - } \\ \varepsilon_{0} & \text { Constant in pressure drop equation } \\ \varnothing & \text { Level-set function } \\ \lambda & \text { Constant for correlation in Table } 7,- \\ \mu_{c} & \text { Viscosity of the continuous phase } \\ \mu_{d} & \text { Viscosity of the dispersed phase } \\ \eta & \text { Variable in pressure drop equation } \\ \rho & \text { Density } \\ \sigma & \text { Surface tension } \\ \varphi_{g} & \text { Gas phase hold up in Table 7, - } \\ \tau & \text { Contact time of aqueous and organic phases in micro-channel } \\ & \end{array}$

\section{References}

1. Kashid, M.N.; Harshe, Y.M.; Agar, D.W. Liquid-liquid slug flow in a capillary: An alternative to suspended drop or film contactors. Ind. Eng. Chem. Res. 2007, 46, 8420-8430. [CrossRef]

2. Cademartori, S.; Cravero, C.; Martini, M.; Marsano, D. CFD Simulation of the Slot Jet Impingement Heat Transfer Process and application to a temperature control system for galvanizing line of metal band. Appl. Sci. 2021, 11, 1149. [CrossRef]

3. Cravero, C.; Domenico, D.; Leutcha, P.J.; Marsano, D. Strategies for the Numerical Modeling of Regenerative Preheating systems for recycled glass raw material. Math. Model. Eng. Probl. 2019, 6, 324-332. [CrossRef]

4. Dixit, T.; Ghosh, I. Review of micro-and mini-channel heat sinks and heat exchangers for single phase fluids. Renew. Sustain. Energy Rev. 2015, 41, 1298-1311. [CrossRef]

5. Al-Azzawi, M.; Mjalli, F.S.; Husain, A.; Al-Dahhan, M. A Review on the hydrodynamics of the Liquid-Liquid two-phase flow in the microchannels. Ind. Eng. Chem. Res. 2021, 60, 5049-5075. [CrossRef]

6. Kashid, M.N.; Renken, A.; KiwiMinsker, L. Gas-liquid and liquid-liquid mass transfer in microstructured reactors. Chem. Eng. Sci. 2011, 66, 3876-3897. [CrossRef]

7. Yagodnitsyna, A.A.; Kovalev, A.V.; Bilsky, A.V. Flow patterns of immiscible liquid-liquid flow in a rectangular microchannel with T-junction. Chem. Eng. J. 2016, 303, 547-554. [CrossRef]

8. Kovalev, A.V.; Yagodnitsyna, A.A.; Bilsky, A.V. Flow hydrodynamics of immiscible liquids with low viscosity ratio in a rectangular microchannel with T-junction. Chem. Eng. J. 2018, 352, 120-132. [CrossRef]

9. Dessimoz, A.L.; Cavin, L.; Renken, A.; Kiwi-Minsker, L. Liquid-liquid two-phase flow patterns and mass transfer characteristics in rectangular glass microreactors. Chem. Eng. Sci. 2008, 63, 4035-4044. [CrossRef]

10. Bai, L.; Zhao, S.; Fu, Y.; Cheng, Y. Experimental study of mass transfer in water/ionic liquid microdroplet systems using micro-LIF technique. Chem. Eng. J. 2016, 298, 281-290. [CrossRef]

11. Wu, Z.; Cao, Z.; Sunden, B. Flow patterns and slug scaling of liquid-liquid flow in square microchannels. Int. J. Mult. Flow. 2019, 112, 27-39. [CrossRef]

12. Zhang, Q.; Liu, H.; Zhao, S.; Yao, C.; Chen, G. Hydrodynamics and mass transfer characteristics of liquid-liquid slug flow in microchannels: The effects of temperature, fluid properties and channel size. Chem. Eng. J. 2019, 358, 794-805. [CrossRef]

13. Kashid, M.N.; Gerlach, I.; Goetz, S.; Franzke, J.; Acker, J.F.; Platte, F.; Agar, D.W.; Turek, S. Internal circulation within the liquid slugs of liquid-liquid slug flow capillary micro-reactor. Ind. Eng. Chem. Res. 2005, 44, 5003-5010. [CrossRef]

14. Kashid, M.N.; Rivas, D.F.; Agar, D.W.; Turek, S. On the hydrodynamics of liquid-liquid slug flow capillary microreactors. Asia-Pac. J. Chem. Eng. 2008, 3, 151-160. [CrossRef] 
15. Cao, Z.; Wu, Z.; Sattari-Najafabadi, M.; Sunden, B. Liquid-liquid flow patterns in micro-channels. In Heat Transfer Summer Conference; American Society of Mechanical Engineers: Bellevue, WA, USA, 2017.

16. Zhao, Y.; Chen, G.; Yuan, Q. Liquid-liquid two-phase mass transfer in the T-junction microchannels. AlChE J. 2007, 53, 3042-3053. [CrossRef]

17. Cubaud, T.; Mason, T.G. Capillary threads and viscous droplets in square microchannels. Phys. Fluids 2008, 20, 053302. [CrossRef]

18. Fu, T.; Wu, Y.; Ma, Y.; Li, H.Z. Droplet formation and breakup dynamics in microfluidic flow-focusing devices: From dripping to jetting. Chem. Eng. Sci. 2012, 84, 207-217. [CrossRef]

19. Carrier, O.; Funfschilling, D.; Li, H.Z. Effect of the fluid injection configuration on droplet size in a microfluidic T junction. Phys. Rev. E 2014, 89, 013003. [CrossRef]

20. Du, W.; Fu, T.; Ma, Y.; Li, H.Z. Breakup dynamics for high-viscosity droplet formation in a flow-focusing device: Symmetrical and asymmetrical ruptures. AlChE J. 2016, 62, 325-337. [CrossRef]

21. Van Loo, S.; Soukatch, S.; Gilet, T. Droplet formation by squeezing in a microfluidic cross-junction. Microfluid. Nanofluidics 2016, 20, 146. [CrossRef]

22. Foroughi, H.; Kawaji, M. Viscous oil-water flows in a microchannel initially saturated with oil: Flow patterns and pressure drop characteristics. J. Multiph. Flow 2011, 37, 1147-1155. [CrossRef]

23. Azarmanesh, M.; Farhadi, M. The effect of weak-inertia on droplet formation phenomena in T-junction microchannel. Meccanica 2016, 51, 819-834. [CrossRef]

24. Svensson, A.; Wu, Z.; Sunden, B. Effects of size and sodium dodecyl sulfate on mass transfer for liquid-liquid two-phase flow in non-circular glass microchannels. In International Conference on Nanochannels, Microchannels, and Minichannels; American Societyof Mechanical Engineers: Vienna, Austria, 2018; p. V001T01A001.

25. Kashid, M.N.; Renken, A.; Kiwi-Minsker, L. CFD modelling of liquid-liquid multiphase microstructured reactor: Slug flow generation. Chem. Eng. Res. Des. 2010, 88, 362-368. [CrossRef]

26. Kashid, M.; Kiwi-Minsker, L. Quantitative prediction of flow patterns in liquid-liquid flow in micro-capillaries. Chem. Eng. Process. Process Intensifi. 2011, 50, 972-978. [CrossRef]

27. Tsaoulidis, D.; Dore, V.; Angeli, P.; Plechkova, N.V.; Seddon, K.R. Flow patterns and pressure drop of ionic liquid-water two-phase flows in microchannels. Int. J. Mult. Flow 2013, 54, 1-10. [CrossRef]

28. Sugiura, S.; Nakajima, M.; Oda, T.; Seki, M. Effect of interfacial tension on the dynamic behavior of droplet formation during microchannel emulsification. J. Colloid. Interface Sci. 2004, 269, 178-185. [CrossRef]

29. Yagodnitsyna, A.A.; Kovalev, A.V.; Bilsky, A.V. Experimental study of ionic liquid-water flow in T-shaped microchannels with different aspect ratios. In Journal of Physics: Conference Series; IOP Publishing: Mexican City, Mexico, 2017; p. 032026.

30. Yagodnitsyna, A.; Kovalev, A.; Bilsky, A. Experimental investigation of immiscible liquids flow in a T-shaped microchannel. In Proceedings of the 10th Pacific Symposium on Flow Visualization and Image Processing, Naples, Italy, 15-18 June 2015; pp. 1-10.

31. Su, Y.; Chen, G.; Yuan, Q. Effect of viscosity on the hydrodynamics of liquid processes in microchannels. Chem. Eng. Technol. 2014, 37, 427-434. [CrossRef]

32. Garstecki, P.; Fuertsman, M.J.; Stone, H.A.; Whitesides, G.M. Formation of droplets and bubbles in a microfluidic T-junctionscaling and mechanism of break-up. Lab Chip 2006, 6, 437-446. [CrossRef]

33. Vansteene, A.; Jasmin, J.; Cavadias, S.; Clarisse, M.; Cote, G. Towards chip prototyping: A model for droplet formation at both T and $X$ junctions in dripping regime. Microfluid. Nanofluidics 2018, 22, 1-14. [CrossRef]

34. Li, Y.; Wang, J.; Li, D.; Liu, R. Flow pattern diagrams of oil-water two-phase microflows and stable parallel flows obtained at low Reynolds numbers. Int. J. Multiph. Flow 2018, 98, 139-146. [CrossRef]

35. Li, M.; Liu, Z.; Pang, Y.; Yan, C.; Wang, J.; Zhao, S.; Zhou, Q. Flow topology and its transformation inside droplets traveling in rectangular microchannels. Phys. Fluids 2020, 32, 052009.

36. Liu, Z.; Li, M.; Pang, Y.; Zhang, L.; Ren, Y.; Wang, J. Flow characteristics inside droplets moving in a curved microchannel with rectangular section. Phys. Fluids 2019, 31, 022004.

37. Fu, B.R. Liquid-liquid mixtures flow in micro-channels. In Transactions of the Canadian Society of Mechanical Engineering; Canadian Science Publishing: Ottawa, ON, Canada, 2013; pp. 631-640.

38. Ladosz, A.; Von Rohr, P.R. Pressure drop of two-phase liquid-liquid slug flow in square micro-channels. Chem. Eng. Sci. 2018, 191, 398-409. [CrossRef]

39. Kashid, M.N.; Agar, D.W. Hydrodynamics of liquid-liquid slug flow capillary microreactor:flow regimes, slug size and pressure drop. Chem. Eng. J. 2007, 131, 1-13.

40. Jovanović, J.; Zhou, W.; Rebrov, E.V.; Nijhuis, T.A.; Hessel, V.; Schouten, J.C. Liquid-liquid slug flow: Hydrodynamics and pressure drop. Chem. Eng. Sci. 2011, 66, 42-54. [CrossRef]

41. Kashid, M.N.; Agar, D.W.; Turek, S. CFD modelling of mass transfer with and without chemical reaction in the liquid-liquid slug flow microreactor. Chem. Eng. Sci. 2007, 62, 5102-5109. [CrossRef]

42. Salim, A.; Fourar, M.; Pironon, J.; Sausse, J. Oil-water two-phase flow in microchannels: Flow patterns and pressure drop measurements. Can. J. Chem. Eng. 2008, 86, 978-988. [CrossRef]

43. Bretherton, F.P. The motion of long bubbles in tubes. J. Fluid Mech. 1961, 10, 166-188. [CrossRef]

44. Raj, R.; Mathur, N.; Buwa, V.V. Numerical Simulations of Liquid-Liquid Flows in Microchannels. Ind. Eng. Chem. Res. 2010, 49, 10606-10614. [CrossRef] 
45. Harries, N.; Burns, J.R.; Barrow, D.A.; Ramshaw, C. A numerical model for segmented flow in a microreactor. Int. J. Heat Mass Transfer 2003, 46, 3313-3322. [CrossRef]

46. Harlow, F.H.; Welch, J.E. Numerical Calculation of Time-Dependent Viscous Incompressible Flow of Fluid with Free Surface. Phys. Fluids 1965, 8, 2182-2189. [CrossRef]

47. Olsson, E.; Kreiss, G. A conservative level-set method for two phase flow. J. Comp. Phys. 2005, 210, 225-246. [CrossRef]

48. Olsson, E.; Kreiss, G.; Zahedi, S. A conservative level-set method for two phase flow-II. J. Comp. Phys. 2007, 225, 785-807. [CrossRef]

49. Brackbill, J.U.; Kothe, D.B.; Zemach, C.A. A continuum method for modeling surface tension. J. Comp. Phys. 1992, 100, 335-354. [CrossRef]

50. Osher, S.; Fedkiw, R.P. Level Set Methods: An Overview and Some Recent Results. J. Comp. Phys. 2001, 169, 463-502. [CrossRef]

51. Van Sind Annaland, M.; Dijkhuisen, W.; Deen, N.G.; Kuipers, J.A.M. Numerical simulations of behavior of gas bubbles using a 3-D front-tracking method. AlChE J. 2006, 52, 99-110. [CrossRef]

52. Hirt, C.W.; Nichols, B.D. Volume of Fluid (VOF) method for the dynamics of free boundaries. J. Comp. Phys. 1981, 39, 201-225. [CrossRef]

53. Kashid, M.N.; Platte, F.; Agar, D.W.; Turek, S. Computational modelling of slug flow in a capillary microreactor. J. Comp. Appl. Math. 2007, 203, 487-497. [CrossRef]

54. Yamasaki, Y.; Kariasaki, A.; Morooka, S. Hydrophilic and hydrophobic modifications of microchannel inner walls for liquid-liquid laminar layered flows. Int. J. Chem. React. Eng. 2010, 8, 1-16. [CrossRef]

55. Kositanont, C.; Tagawa, T.; Yamada, H.; Putivisutisak, S.; Assabumrungrat, S. Effect of surface modification on parallel flow in microchannel with guideline structure. Chem. Eng. J. 2013, 215, 404-410. [CrossRef]

56. Lan, W.; Li, S.; Wang, Y.; Luo, G. CFD simulation of droplet formation in microchannels by a modified level set method. Ind. Eng. Chem. Res. 2014, 53, 4913-4921. [CrossRef]

57. Yang, L.; Ladosz, A.; Jensen, K.F. Analysis and simulation of multiphase hydrodynamics in capillary microseparators. Lab Chip 2019, 19, 706-715. [CrossRef]

58. De Menech, M.; Garstecki, P.; Jousse, F.; Stone, S.A. Transition from squeezing to dripping in a microfluidic T-shaped junction. J. Fluid Mech. 2008, 595, 141-161. [CrossRef]

59. Han, W.; Chen, X. New insights into the pressure during the merged droplet formation in the squeezing time. Chem. Eng. Res. Des. 2019, 145, 213-225. [CrossRef]

60. Sripadaraja, K.; Umesh, G.; Satyanarayan, M.N. Simulation studies on picolitre volume droplets generation and trapping in T-junction microchannels. SN Appl. Sci. 2020, 2, 1413. [CrossRef]

61. Rider, W.J.; Kothe, D.B. Reconstructing volume tracking. J. Comp. Phys. 1998, 141, 112-152. [CrossRef]

62. Unverdi, S.O.; Trygvasson, G. A front-tracking method for viscous, incompressible, multi-fluid flows. J. Comp. Phys. 1992, 100, 25-37. [CrossRef]

63. Koynov, A.; Khinast, J.G.; Tryggvason, G. Mass transfer and chemical reactions in bubble swarms with dynamic interfaces. AlChE J. 2005, 51, 2786-2800. [CrossRef]

64. TeGrotenhuis, W.E.; Cameron, R.J.; Butcher, M.G.; Martin, P.M.; Wegeng, R.S. Microchannel devices for efficient contacting of liquids in solvent extraction. Sep. Sci. Technol. 1999, 34, 951-974. [CrossRef]

65. Burns, J.R.; Ramshaw, C. The intensification of rapid reactions in multiphase systems using slug flow in capillaries. Lab Chip 2001, 1, 10-15. [CrossRef] [PubMed]

66. Ghaini, A.; Kashid, M.N.; Agar, D.W. Effective interfacial area for mass transfer in the liquid-liquid slug flow capillary microreactors. Chem. Eng. Process. Process Intensif. 2010, 49, 358-366. [CrossRef]

67. Assmann, N.; Von Rohr, P.R. Extraction in microreactors: Intensification by adding an inert gas phase. Chem. Eng. Process. Process Intensif. 2011, 50, 822-827. [CrossRef]

68. Ufer, A.; Sudhoff, D.; Mescher, A.; Agar, D.W. Suspension catalysis in a liquid-liquid capillary microreactor. Chem. Eng. J. 2011, 167, 468-474. [CrossRef]

69. Xu, B.; Cai, W.; Liu, X.; Zhang, X. Mass transfer behavior of liquid-liquid slug flow in circular cross-section microchannel. Chem. Eng. Res. Des. 2013, 91, 1203-1211. [CrossRef]

70. Di Miceli Raimondi, N.; Prat, L.; Gourdon, C.; Tasselli, J. Experiments of mass transfer with liquid-liquid slug flow in square microchannels. Chem. Eng. Sci. 2014, 105, 169-178. [CrossRef]

71. Arsenjuk, L.; Kaske, F.; Franzke, J.; Agar, D.W. Experimental investigation of wall film renewal in liquid-liquid slug flow. Int. J. Mult. Flow 2016, 85, 177-185. [CrossRef]

72. Li, Q.; Angeli, P. Intensified Eu (III) extraction using ionic liquids in small channels. Chem. Eng. Sci. 2016, 143, 276-286. [CrossRef]

73. Matsuoka, A.; Noishiki, K.; Mae, K. Experimental study of the contribution of liquid film for liquid-liquid Taylor flow mass transfer in a micro-channel. Chem. Eng. Sci. 2016, 155, 306-313. [CrossRef]

74. Sattari-Najafabadi, M.; Nasr Esfahany, M.; Wu, Z.; Sunden, B. Hydrodynamics and mass transfer in liquid-liquid non-circular microchannels: Comparison of two aspect ratios and three junction structures. Chem. Eng. J. 2017, 322, 328-338. [CrossRef]

75. Sattari-Najafabadi, M.; Esfahany, M.N.N. Intensification of liquid-liquid mass transfer in a circular microchannel in the presence of sodium dodecyl sulfate. Chem. Eng. Process. Process Intensif. 2017, 117, 9-17. [CrossRef] 
76. Singh, K.K.; Renjith, A.U.; Shenoy, K.T. Liquid-liquid extraction in microchannels and conventional stage-wise extractors: A comparative study. Chem. Eng. Process. 2015, 98, 95-105. [CrossRef]

77. Sahu, A.; Vir, A.B.; Molleti, L.N.S.; Ramji, S.; Pushpavanam, S. Comparison of liquid-liquid extraction in batch systems and micro-channels. Chem. Eng. Process. Process Intensif. 2016, 104, 190-200. [CrossRef]

78. He, Y.; Chen, K.; Srinivasakannan, C.; Li, S.; Yin, S.; Peng, J.; Guo, S.; Zhang, L. Intensified extraction and separation Pr(III)/ Nd(III) from chloride solution in presence of a complexing agent using a serpentine microreactor. Chem. Eng. J. 2018, 354, 1068-1074. [CrossRef]

79. Jiang, F.; Yin, S.; Srinivasakannan, C.; Peng, J. Separation of lanthanum and cerium from chloride medium in presence of complexing agent along with EHEHPA (P507) in a serpentine microreactor. Chem. Eng. J. 2018, 334, 2208-2214. [CrossRef]

80. Sen, N.; Darekar, M.; Sirsat, P.; Singh, K.K.; Mukhopadhyay, S.; Shirsath, S.R.; Shenoy, K.T. Recovery of uranium from lean streams by extraction and direct precipitation in microchannels. Sep. Purif. Technol. 2019, 227, 115641. [CrossRef]

81. Tang, J.; Zhang, X.; Cai, W.; Wang, F. Liquid-liquid extraction based on droplet flow in a vertical micro-channel. Exp. Therm. Fluid Sci. 2013, 49, 185-192. [CrossRef]

82. Tsaoulidis, D.; Angeli, P. Effect of channel size on mass transfer during liquid-liquid plug flow in small scale extractors. Chem. Eng. J. 2015, 262, 785-793. [CrossRef]

83. Ani, Z.; Wahabi, T.A.; Mjalli, F.; Hashmi, A.A.; Idayil, B. Flow of deep eutectic solvent-simulated fuel in circular channels: Part II-Extraction of dibenzothiophene. Chem. Eng. Res. Des. 2017, 119, 294-300. [CrossRef]

84. He, Y.; Zeng, T.; Chen, K.; Ullah, E.; Li, S.; Zhang, L.; Yina, S.; Guo, S.; Jin, B.; Rene, S. Solvent extraction performance of Sm(III) using a T-junction microreactor with 2-ethylhexyl phosphonic acid mono-2-ethylhexyl (EHEHPA). Chem. Eng. Process. Process Intensif. 2019, 136, 28-35. [CrossRef]

85. Yao, C.; Ma, H.; Zhao, Q.; Liu, Y.; Chen, G. Mass transfer in liquid-liquid Taylor flow in a microchannel: Local concentration distribution, mass transfer regime and the effect of fluid viscosity. Chem. Eng. Sci. 2020, 223, 115734. [CrossRef]

86. Zhang, Y.; Zhang, X.; Xu, B.; Cai, W.; Wang, F. CFD simulation of mass transfer intensified by chemical reactions in slug flow microchannels. Can. J. Chem. Eng. 2015, 93, 2307-2314. [CrossRef]

87. Bothe, D.; Koebe, M.; Wielage, K.; Warnecke, H.J. VOF simulations of mass transfer from single bubbles and bubble chains rising in aqueous solutions. In Proceedings of the 4th ASME/JSME Joint Fluids Summer Engineering Conference, Honolulu, HI, USA, 6-10 July 2003; pp. 423-429.

88. Gómez-Pastora, J.; González-Fernández, C.; Fallanza, M.; Bringas, E.; Oritz, I. Flow patterns and mass transfer performance of miscible liquid-liquid flows in various microchannels: Numerical and experimental studies. Chem. Eng. J. 2018, 344, 487-497. [CrossRef]

89. Di Miceli Raimondi, N.; Prat, L.; Gourdon, C.; Cognet, P. Direct numerical simulations of mass transfer in square micro-channels for liquid-liquid slug flow. Chem. Eng. Sci. 2008, 63, 5522-5530. [CrossRef]

90. Cito, S.; Pallares, J.; Fabregat, A.; Katakis, I. Numerical simulation of wall mass transfer rates in capillary-driven flow in microchannels. Int. Comm. Heat Mass Transfer 2012, 39, 1066-1072. [CrossRef]

91. Ramji, S.; Puspavanam, S. Liquid-liquid extraction in laminar two-phase stratified flows in capillary microchannels. Chem. Eng. Sci. 2019, 195, 242-249. [CrossRef]

92. Yang, C.; Mao, Z.S. Numerical simulation of interphase mass transfer with the level set approach. Chem. Eng. Sci. 2005, 60, 2643-2660. [CrossRef]

93. Haroun, Y.; Legendre, D.; Raynal, L. Volume of fluid method for interfacial reactive mass transfer: Application to stable liquid film. Chem. Eng. Sci. 2010, 65, 2896-2909. [CrossRef]

94. Kenig, E.K.; Ganguli, A.A.; Atmakidis, T.; Chasanis, P. A novel method to capture mass transfer phenomena at free fluid-fluid interfaces. Chem. Eng. Process. Process Intensif. 2011, 50, 68-76. [CrossRef]

95. Skelland, A.H.P.; Wellek, R.M. Resistance to mass transfer inside droplets. AlChE J. 1964, 10, 491-496. [CrossRef]

96. Van Baten, J.M.; Krishna, R. CFD Modeling of a Bubble Column Reactor carrying out a consecutive A $\rightarrow$ B $\rightarrow$ C Reaction. Chem. Eng. Technol. 2004, 27, 398-406. [CrossRef]

97. Sherwood, T.K.; Wei, J.C. Interfacial phenomena in liquid extraction. Ind. Eng. Chem. 1957, 49, 1030-1034. [CrossRef]

98. Asthana, A.; Zinovik, I.; Weinmueller, C.; Poulikakos, D. Significant Nusselt number increase in microchannels with a segmented flow of two immiscible liquids: An experimental study. Int. J. Heat Mass Transfer 2011, 54, 1456-1464. [CrossRef]

99. Giolla Eain, M.; Egan, V.; Punch, J. Local Nusselt number enhancements in liquid-liquid Taylor flows. Int. J. Heat Mass Transfer 2015, 80, 85-97. [CrossRef]

100. Dai, Z.; Guo, Z.; Fletcher, F.; Haynes, B.S. Taylor flow heat transfer in microchannels-unification of liquid-liquid and gas-liquid results. Chem. Eng. Sci. 2015, 138, 140-152. [CrossRef]

101. Abdollahi, A.; Norris, S.E.; Sharma, R.N. Fluid flow and heat transfer of liquid-liquid Taylor flow in square microchannels. Appl. Therm. Eng. 2020, 172, 115123. [CrossRef]

102. Vivekanand, S.V.B.; Raju, V.R.K. Numerical study of the hydrodynamics and heat transfer characteristics of liquid-liquid Taylor flow in microchannel. Heat Transfer-Asian Res. 2018, 47, 794-805. [CrossRef]

103. Urbant, P.; Leshansky, A.; Halupovic, Y. On the forced convective heat transport in a droplet-laden flow in microchannels. Microfluid. Nanofluidics 2008, 4, 533-542. [CrossRef] 
104. Fischer, M.; Juric, D.; Poulikakos, D. Large convective heat transfer enhancement in microchannels with a train of coflowing immiscible or colloidal droplets. J. Heat Transfer 2010, 132, 112402. [CrossRef]

105. Che, Z.; Wong, T.N.; Nguyen, N.T. Heat transfer enhancement by recirculating flow within liquid plugs in microchannels. Int. J. Heat Mass Transfer 2012, 55, 1947-1956. [CrossRef]

106. Che, Z.; Wong, T.N.; Nguyen, N.T. Heat transfer in plug flow in cylindrical microcapillaries with constant surface heat flux. Int. J. Therm. Sci. 2013, 64, 204-212. [CrossRef]

107. Bandara, T.; Cheung, S.C.P.; Rosengarten, G. Slug flow heat transfer in microchannels: A numerical study. Comput. Therm. Sci. 2015, 7, 81-92. [CrossRef] 